University of Rhode Island

DigitalCommons@URI

Open Access Master's Theses

1999

\title{
THE ANALYSIS OF THE FORESTRY PRACTICES REFERENDA IN THE STATE OF MAINE IN 1996 AND 1997
}

Douglas G. McGovern

University of Rhode Island

Follow this and additional works at: https://digitalcommons.uri.edu/theses

\section{Recommended Citation}

McGovern, Douglas G., "THE ANALYSIS OF THE FORESTRY PRACTICES REFERENDA IN THE STATE OF MAINE IN 1996 AND 1997" (1999). Open Access Master's Theses. Paper 516.

https://digitalcommons.uri.edu/theses/516

This Thesis is brought to you for free and open access by DigitalCommons@URI. It has been accepted for inclusion in Open Access Master's Theses by an authorized administrator of DigitalCommons@URI. For more information, please contact digitalcommons-group@uri.edu. 
THE ANALYSIS OF THE FORESTRY PRACTICES REFERENDA IN THE STATE OF MAINE IN 1996 AND 1997

By

Douglas G. McGovern

A RESEARCH PROJECT SUBMITTED IN PARTIAL FULFILLMENT OF THE

REQUIREMENTS FOR THE DEGREE OF MASTER OF COMMUNITY

PLANNING

UNIVERSITY OF RHODE ISLAND

1999 
THE ANALYSIS OF THE FORESTRY PRACTICES REFERENDA IN THE STATE OF MAINE IN 1996 AND 1997

\author{
Research Project \\ of \\ Douglas G. McGovern
}

Approved:

Major Professor

Acknowledged:

Director 


\begin{abstract}
This research project describes and explains the 1996 and 1997 Maine forestry practices referenda. which came about amid heightened concern about threats to Maine's large tracts of privately-owned forestlands. part of a larger area known as the Northern Forest. It explores the factors influencing how people cast their votes in the two referenda and the ties between these factors and the spatial patterns of the votes.

This research shows that in addition to concern for the environment. economic considerations of individuals were an important factor with regard to how people cast their votes. Attempts to influence voter opinion by the different sides in this issue with media messages also played an important. although hard to quantify role in the ultimate defeat of any changes to existing forestry practices regulations. Analysis of voting patterns suggests an important role for grassroots environmental and property rights groups in influencing the outcome of these referenda.

The ballot questions put before Maine voters are of particular importance in deciding the future of the Northern Forest. an important economic. recreational and ecological resource that the proposed changes to forestry practices regulations would have affected. This resource stretches into several neighboring states who may use this research to gauge citizen reaction to changes in forestry regulations.
\end{abstract}




\section{Acknowledgements}

I would like to thank Dr. Farhad Atash and Dr. Howard Foster for their constructive and thoughtful guidance and encouragement throughout the entire process of creating this document. I am indebted to Dr. Rolf Pendall whose incredible enthusiasm for the study of land use issues helped inspire me to investigate this very interesting and important topic. I would also like to recognize the support of the Rhode Island Agricultural Experiment Station, who provided funding for part of this research. Most of all I would like to thank my wife Galen for supporting me throughout my tenure in the Community Planning and Area Development program. 


\section{Table of Contents}

Abstract

Acknowledgements

Table of Contents iii-v

List of Tables vi vi

List of Figures vii

\begin{tabular}{ll} 
Chapter One: Introduction & 1 \\
\hline Objectives of the Research & 3
\end{tabular}

Research Hypotheses 4

Research Methodologies 8

Significance of the Research 9

Limitations of the Research 9

Chapter Two: Literature Review $\quad 10$

$\begin{array}{ll}\text { Introduction } & 10\end{array}$

Maine`s Forest-Based Economy 10

Maine`s Demographics $\quad 13$

Maine Land Use 13

$\begin{array}{lr}\text { The Northern Forest } & 13\end{array}$

$\begin{array}{ll}\text { Ownership } & 14\end{array}$

$\begin{array}{ll}\text { Industrial Land Use Practices } & 15\end{array}$

Maine Land Use Regulator Structure' 15

Land Use Policy Development 16

$\begin{array}{ll}\text { General Background on Referenda and Initiatives } & 17\end{array}$

Summary of Advantages of Initiatives and Referenda 19

Summary of Disadvantages of Initiatives and Referendia 20

Referenda. Initiatives and Campaign Spending 20

Media Influence on Referenda and Initiative Voting 21

Correlation Between the Referenda Votes and Economic and

Demographic Characteristics of Areas $\quad 22$

Findings $\quad 23$

Chapter Three: Maine in Profile $r 25$

$\begin{array}{lr}\text { Introduction } & 25\end{array}$

Sources of Information $\quad 25$

$\begin{array}{ll}\text { Geography } & 27\end{array}$

Overview of Maine Forest Land Use Ownership $\quad 30$

Demographics 33 
Chapter Three: Maine in Profile

State Land Use Regulatory Structure and Policy Development $\quad 43$

General Overview of Maine's Regulaton. Structure $\quad 45$

Local Land Use Regulation 47

Maine's Land Use Policy-Making Agencies 47

The Northern Forest Lands Study and the Northern Forest Lands Council 48

Maine Counties in Profile

Androscoggin Count. 51

Aroostook Countr. $\quad 52$

Cumberland Count

Franklin Count. $\quad 54$

Hancock Count.

Kennebec Countr.

Knox County

Lincoln Countr. 58

Oxford Counti $\quad 59$

Penobscot Countr. $\quad 60$

Piscataquis County

Sagadahoc Counn $\quad 62$

Somerset Countr.

Waldo Count. 65

Washington Countr.

York Counț $\quad 66$

$\begin{array}{ll}\text { Findings } & 70\end{array}$

\begin{tabular}{ll} 
Chapter Four: The 1996 and 1997 Maine Forestry Practices Referenda & 73 \\
\hline Introduction & 73
\end{tabular}

The Diamond International Deal 74

The 1996 and 1997 Forestry Practices Referenda 76

The "Ban Clearcutting" Initiative 76

$\begin{array}{ll}\text { A Response to the Initiative } & 78\end{array}$

A Third Option 81

The 1996 Referendum Campaign $\quad 82$

The 1996 Referendum Results $\quad 83$

Geographic Information Systems Data and Methodology 84

Distribution of the Votes $\quad 86$

The Runoff Election $\quad 94$

The Role of the Media in the 1997 Election 96

The 1997 Voting Results 96

After Defeat $\quad 99$

$\begin{array}{ll}\text { Findings } & 100\end{array}$ 
Chapter Five: Analysis, Discussion and Conclusion

104

Introduction

Methods for Using Inferential Statistics for Hypothesis Testing 104

Research Hypotheses

107

Findings

108

Spatial Analysis

110

Municipal Referendum Votes and Large Paper Manufacturing Facilities

113

Statistical Correlation Between Referenda Votes and Social and Demographic

Variables

116

Chi Square Analysis

117

Multiple Regression Analysis

117

Independent Variables and the 1996 2a (Ban Clearcutting) Vote

120

Independent Variables and the 1996 2b (Compact) Vote

121

Independent Variables and the 1996 2c (None of the Above) Vote 122

Independent Variables and the 1997 2b Compact Vote (yes/no) 122

Agreement Between Results of Descriptive and Quantitative Analysis 123

Findings

123

Discussion

124

The Role of the Media in the 1996 and 1997 Elections 128

Conclusion

Bibliography

Appendix A: Maine 1995 Employment and Payroll by County

\section{Appendix B: LD 1892 An Act to Implement the Compact for Maine's} Forests 
Table 3.1 Maine Land Ownership 1994

Table 3.2 Maine Population and Population Growth 33

Table 3.3 SIC Sectors and Major Groups 37

Table 3.4 Maine Employment 1995 by Sector $\quad+1$

Table 3.5 Regulations Affecting Forest landowners in Maine's Northern Forest +5

Table 3.6 Maine Counties: General Profile 68-69

Table 4.1 Total Votes on Question 2 Options by County 84

Table 4.2 Counties Showing the Greatest and Least Support for Ban Clearcutting; 1996 Question 2a 88

Table 4.3 Counties Showing the Greatest and Least Support for the Compact:1996 Question 2b 89

Table 4.4 Counties Showing the Greatest and Least Support for None of the Above; 1996 Question 2c 91

Table 4.5 Counties Showing the Greatest and Least Support for the Compact: 1997 Question 1

Table 5.1 Variables Used for Statistical Analysis 106

Table 5.2 Referendum Vote Analysis: Vote on Compact 1996 vs. 108

Table 5.3 Referendum Vote Analysis by Municipality: Vote on

Table 5.4 Large Paper Manufacturing Facilities and the 1996/1997 Referendum Votes $\quad 115$

Table 5.5 Multiple Regression - Clearcut Ban $1996 \quad 119$

Table 5.6 Multiple Regression - Compact for Maine`s Forests $1996 \quad 119$

Table 5.7 Multiple Regression - None of the Above $1996 \quad 119$

Table 5.8 Multiple Regression - Compact for Maine s Forests $1997 \quad 120$ 
List of Figures Page

Figure 3.1 Topographic Areas 29

Figure 3.2 Northern Forest Land Survey 1993 Woodlot Ownership 31

Figure 3.3 Maine Counties 35

Figure 3.4 Maine Employment $1995 \quad 40$

Figure 3.5 Land Use Regulatory Commission (LURC) Jurisdiction 44

Figure 4.1 1996 Support for "Ban Clearcutting" Referendum Question 2a by County $\quad 87$

Figure 4.2 1996 Support for "Compact for Maine"s Forests" Referendum Question 2b by County 90

Figure 4.31997 Support for "None of the Above" Referendum Question 2c by County 92

Figure 4.4 1997 Support for "Compact for Maine's Forests" Referendum Question 1 by County 98

Figure 5.1 1996-1997 Compact Support and Opposition 112 


\section{Chapter One}

\section{Introduction}

In 1996 and 1997. Maine voters considered - and rejected - fundamental changes in land-use regulation for $50 \%$ of their state's territory. Presented with the opportunity to ban clearcutting or at least to impose less restrictive new regulations, a majority of voters did not select either choice. The next year, the majority of voters rejected less restrictive new regulations in a runoff election resulting from requirements in the Maine Constitution that voters accept or reject ballot measures by more than $50 \%$. The forestry initiative/referenda can be interpreted as debates over both land-use regulations and property rights during a time of increased globalization. which places pressure on large landowners to maximize the economic return on their landholdings. For planners and land managers, this suggests the need for an understanding of voter behavior and the process of changing land-use regulations in order to develop an effective response to society's conflicting demands on diminishing natural resources.

One of Maine's most important natural resources from an ecological. economic and social perspective is its vast tracts of timberlands which comprise part of the Northern Forest, which stretches across northern New England and New York. Unlike the forestlands in the western and other areas of the United States, which are largely in public stewardship. Maine`s forestlands are primarily under private ownership. Among these private owners, multinational corporations involved in the forest products industry are by far the largest in terms of area owned. These corporations are increasingly subject 
to the forces of the global economy, where business cycles and accompanying flow of capital can have great impact on local and regional land use.

This situation has generated a great deal of concern among environmentalists and forest users in general as forest products companies become more aggressive in finding ways to maximize returns to shareholders. One way the companies do this is to shift capital by liquidating forest landholdings through outright sales or by increasing the timber harvest to generate cash.

One way to increase harvest efficiency that is of particular concern to environmentalists is the practice of clearcutting, where all of the commercially valuable trees in large contiguous areas are removed. Many view clearcutting as at least unsightly if not environmentally unsound. While this practice has been used long before globalization of the economy, it has recently become just one issue in the larger debate on the future of the Northern Forest.

In 1995 the Maine Green party led by Jonathan Carter, frustrated by existing forestry practices regulations, began a petition drive to gather enough signatures to place an initiative to ban the practice of clearcutting in Maine's unincorporated territories on the ballot in the 1996 statewide election. Maine's governor, Angus King. forest products industry representatives, and some mainstream environmental groups responded by developing a compromise ballot choice called "the Compact for Maine "s Forests". A third choice, required by Maine's Constitution, was no change to existing forestry practices regulation, which already placed restrictions on clearcutting, although not enough to adequately protect the forest in the view of Carter. 
These ballot choices and the debate surrounding them polarized the population generally into those who feared that further restrictions to clearcutting would cause a loss of jobs and slow the state's economy. which was still recovering from a recession in the late 1980s, and those who feared that global economic forces acting on large forest landholders would lead to increasingly unsustainable forestry practices and loss of traditional multiple use of the forest resource. In addition. many property rights groups were opposed to any kind of additional regulations on the use of private property and saw both the ban clearcutting and compromise option as unacceptable government interference. All sides of the issue waged a fierce campaign to influence voters and ultimately none of the three ballot choices received more than the $50 \%$ required for passage. Because the Compact received the most votes in 1996. it became subject to a runoff election where voters were given the choice of accepting or rejecting the Compact. In 1997 the Compact was defeated by a close margin. This essentially left the issue of a ban on clearcutting unresolved and likely to resurface as a ballot choice or as legislation in the future.

\section{Objectives of the Research}

The research has three objectives. First, it provides the reader with the necessary economic, social and geographic context for understanding the complex debate surrounding changes to forestry practices regulation that were put before Maine`s voters. Second, it traces the history of initiatives and referenda both generally and specific to the 1996 and 1997 elections and shows the spatial distribution of the votes for the various ballot choices in both years. Third, it examines the relationship between demographic 
and economic variables, and the results of the 1996 and 1997 votes descriptively and quantitatively to determine if they support the research hypotheses described below.

\section{Research Hypotheses}

The first set of hypotheses deal with the relationship between the 1996 and 1997 votes on the compromise option: the Compact for Maine's Forests. The null hypothesis for this relationship is that the votes for the Compact in 1996 and 1997 are independent of each other. The alternative hypothesis is that a vote of yes for the Compact in 1997 was significantly related to a vote of yes for the Compact in 1996, more specifically. that in counties where the majority voted for the Compact in 1996 there was a significant likelihood that the majority would vote for it again in 1997. indicating the presence and location of areas of core support for the Compact.

The second hypothesis deals with the role of media campaigns of the proponents and opponents of the three options in the 1996 election and proponents and opponents of the Compact in the 1997 election. The null hypothesis is that media campaigns did not influence the voting results in either year. The alternative hypothesis is that media campaigns had a strong influence on the voting results in both 1996 and 1997.

Two closely related variables, percent of the age $25+$ population that graduated high school (1990) and percent of the age $25+$ population that graduated college (1990). were used as indicators of social status, which has been demonstrated as a relevant variable in referendum elections (Hahn and Kamieniecki 1986,93-113). Voting preferences of low-status and high-status voters. as indicated by level of education. may be formed by contrasting perceptions of what is in the public interest or general welfare 
of the community. In some conceptualizations of the relationship between status and voting. higher status (more educated) voters "express their tastes, values and lifestyles through the acceptance or rejection of referendum proposals unrelated to major financial considerations" (Hahn and Kamieniecki 1986, 49-50). Along these lines, the null hypothesis is that there is no relationship between votes for any of the 1996 referendum choices and level of education, both high school and college. Alternatively, the research hypothesized that voters in counties with higher education levels will be more likely to vote to ban clearcutting and less likely to support the Compact or None of the Above choices because these voters generally place a higher value on environmental protection and can make this decision independent of financial considerations. Similarly, the null hypothesis for the 1997 vote is that there is no relationship between votes for the 1997 referendum choices and level of education, both high school and college. The alternative hypothesis for 1997 is that counties with higher education levels will be significantly more likely to vote for the Compact than those with lower education levels.

The null hypothesis for per capita income. another indicator of social status. is that it has no significant relationship to the votes in the 1996 or 1997 referenda.

Alternatively, the research hypothesized that counties with higher per capita income would be significantly more likely to vote for the Clearcut Ban and against the Compact or none of the above option in 1996 and for the Compact in 1997.

The variable population density, as measured in persons per square mile in 1995 , was also analyzed as an independent correlate to the 1996 and 1997 referendum votes. This variable serves as an indication of the "ruralness" of the individual counties. The concept of this variable is that there is a land use ethic and lifestyle associated with rural 
living that shapes voter preference. This ethic and lifestyle promotes a strong sense of individualism. self reliance. and accompanying opposition to government intervention into private land use decisions such as changes to forestry practices regulations. In this conceptualization. voters in more rural areas will vote more on the basis of opposition to new government regulation than voters from more urban areas. For this variable the null hypothesis is that there is no significant relationship between the votes for any of the 1996 referendum choices and population density. Alternatively, the research hypothesized that voters in counties with higher population densities would be more likely to vote to ban clearcutting and less likely to vote for the Compact or none of the above in 1996. The null hypothesis remains essentially the same for the 1997 vote (no relationship) while the alternative hypothesis is that counties with higher population densities will be more likely to vote for the Compact.

Another variable closely related to population density is area under the jurisdiction of Maine's Land Use Regulatory Commission (LLRC). This is because the unincorporated areas over which LURC has jurisdiction tend to have very low populations. This variable serves as a rough proxy for the amount of land owned as commercial woodlots and is also closely related to forest products industry employment. the next variable to be discussed (Figure 3.2). This is because the majority of commercial timberlands lie in unincorporated territories under LURC jurisdiction (Bradbury 1996. I). The null hypothesis for this variable is that there is no relationship between the county votes for any of the choices in 1996 and area under LURC jurisdiction. Alternatively. the research hypothesizes that voters in counties with greater area under LURC jurisdiction will be more likely to vote against a ban on clearcutting, against the Compact, and for the 
none of the above option in 1996 . The null hypothesis remains essentially the same for the 1997 (no relationship) vote. while the alternative hypothesis is that voters in counties with greater area under LURC jurisdiction will be more likely to vote against the Compact in 1997. The concept here is that voters in and near areas of extensive LURC jurisdiction will tend to vote against additional state regulation. seeing land use controls in general as a local issue, and forestry practices regulation as a threat to local economic health.

The next two variables and their relationship to the 1996 and 1997 votes lie at the core of the research. which is that in the 1996 and 1997 referenda. voter preference was largely a function of financial considerations. That is, voters in counties that are more economically dependent on the forest products industry were significantly more likely to vote against any regulation that might hinder the industry and cause an accompanying decline in employment. The null hypothesis is that there is no relationship between county votes for any of the three choices in 1996 and forest products industry employment. Alternatively this research hypothesizes that voters in counties with higher forest products industry employment will be more likely to vote against a ban on clearcutting, against the Compact. and for none of the above options. The null hypothesis remains essentially the same for the 1997 vote (no relationship) while the alternative hypothesis is that voters in counties with greater forest products industry employment will be more likely to vote against the Compact in 1997.

Like forest products industry employment, this research hypothesizes that county unemployment would have a similar correlation to the votes as forest products industry employment. although unemployment figures are not necessarily a measure of people 
who had been working in the forest products industry that lost their jobs. The concept of this variable is that many voters equate clearcutting restrictions with a loss of jobs and that voters in areas already experiencing high unemployment relative to the rest of the state would have a concern that the unemployment level would increase. The null hypothesis is that there is no relationship between any of the choices in both the 1996 and 1997 votes and level of unemployment. Alternatively, voters in counties with higher unemployment will be more likely to vote against the clearcut ban and Compact and for the none of the above and then against the Compact in 1997.

\section{Research Methodologies}

Three general methodologies were employed in this research: descriptive analysis. quantitative statistical analysis and spatial analysis. Descriptive analysis was used to assess the role of the media in influencing the 1996 and 1997 election results and the correlation between county characteristics and voting results. Quantitative statistical analysis techniques in the form of chi-square was used to test the hypotheses concerning the correlation between votes for the Compact in 1996 and 1997. Multiple regression analysis was used to test the hypotheses on the correlation between the votes and education level. area under LURC jurisdiction, income, population density. unemployment and forest products industry employment. Spatial analysis was used to examine voting patterns and their proximity to concentrated areas of forest products industry employment and other significant social and geographic features. 


\section{Significance of the Research}

The forestry practices ballot questions put before Maine voters were of great potential importance in deciding future land use in the Northern Forest. An understanding of voter response to the choices presented in 1996 and 1997 and the reasons behind them is especially important because the issue was not resolved and is likely to surface again in the form of a ballot question or in proposed legislation. Another reason that this research is significant is because the Northern Forest stretches into several neighboring states who

may use this research to gauge citizen reaction to future proposed changes in forestry and other land use regulations.

\section{Limitations of the Research}

This study has two limitations. First, much of the analysis was done at the county level due to the availability of County Business Patterns data, and as a result a certain amount of detail is lost. Second, the 1996 and 1997 elections were the result of a complex and unique set of circumstances and caution must be used when applying the finding of this research to other areas and circumstances. 


\section{Chapter Two}

\section{Literature Review}

\section{Introduction}

The purpose of this chapter is to review literature that is relevant to an understanding of Maine s population, economy and geography. This chapter will also review the general literature on referenda. This literature review falls into four distinct categories:

1. Maine's economic and demographic characteristics at the state, regional and county levels;

2. Maine land use, with a particular emphasis on the densely forested northern half of the state, part of what is known as the "Northern Forest":

3. General characteristics of referenda and initiatives. Included in this topical area are the role of politics and the media, and writings on grassroots property rights and environmental organizations; and

4. Correlation between the referenda votes and economic and demographic characteristics of areas.

\section{Maine's Forest-Based Economy}

This section, describing aspects of Maine's economy, is divided by different regional scales, from the global and national level down to the municipal level. At the state level, Maine Business Online ranks the paper industry first in both employment and value of product produced in the manufacturing sector of the economy. The lumber and 
wood products industry ranked third. In combination these two forest products industries have nearly two times the employment of the next largest manufacturing employer. transportation equipment (Haugen 1996. 2). Similarly Land, Timber, and Recreation in Maine's Northwoods, emphasizes the importance of the forest products industry to Maine's economy, concluding that it is making an increasing contribution to total manufacturing production at a time when manufacturing's share of total state employment has declined. Both Irland and Haugen emphasize the cyclical nature of lumber and paper product production and its dependence on the national and international markets. These findings are of particular relevance to this study because the fear that the future of Maine's forests would be determined by forces outside the state was important in pushing the issue of forestry practices regulation to the forefront.

A large, uniform and regularly collected dataset on all the states. including Maine. and individual counties within the states, is collected by the US Bureau of Census in their County Business Patterns. This dataset uses the Standard Industrial Classification (SIC) System which classifies industries into tiered levels of detail. County Business Patterns does not contain any analysis but rather provides the raw material for creating basic economic profiles for counties and for examining the economic structure of regions when aggregated. County Business pattern data include figures for employment, payroll, and number of establishments by employment size classes. This dataset contains basic SIC divisions, or sectors, such as manufacturing and service, and some more specific major groups that include those related to the forest products industry. The Office of Management and Budget's Standard Industrial Classification Manual gives detailed descriptions of what specific activities fall into the major groups. covering most of the 
forest products industry's activities, with the exception of trucking (Office of Management and Budget 1987. 107).

The University of Southern Maine's Center for Business and Economic Research (CBER) publishes the Overall Economic Development Program Supplement that includes employment forecasts and makes comparisons between Maine's economy and those of New England and the Nation which are useful for providing context for discussing the economies of different areas.

Much of the available literature on the forest products industry in Maine focuses on the Northern Forest region of the state. This is the area that proposed changes to forestry practices regulations would effect. According to the findings of technical studies initiated by Northern Forest Lands Council. numerous factors affect employment levels in traditional forest products businesses. namely increased productivity through improvements in production processes. mechanization. and economic cycles of the national and global economy. These factors, in combination. have led to reduced demand for labor in the industry. Also important to the state economy in general, but more specifically to the Northern Forest Area. are the non-industrial activities of fishing. hunting, hiking and other forest-related recreational activities. This report aggregated all of the forest-based industries" economic impacts and calculated the economic value of the Northern Forest industrial output (NFLC 1994).

Klyza and Trombulak, in The Future of the Northern Forest, portray the economies of the Northern Forest counties, especially manufacturing, as more closely linked to the natural resource base than those in the south and coastal regions. They define the Northern Forest counties as Oxford. Franklin. Somerset, Piscataquis. 
Aroostook. Penobscot. Hancock and Washington. and describe the close relationship between timber resources and the economies of these counties. The so-called Northern Forest counties are critical to this study because of its central hypothesis that people in counties that are more dependent on the forest products industry will have a tendency to desire the least restrictions on forestry practices and will vote accordingly.

\section{Maine's Demographics}

The Center for Business and Economic Research (CBER) at the University of Southern Maine publishes the Overall Economic Development Program Supplement detailing county level demographic characteristics such as population density, population distribution, rate of growth, and forecasts of future population size. This report makes comparisons to New England and to the country as a whole to provide the context for the data. Specifically, this report summarizes retirement age (65+) population, education level. size of the civilian labor force, unemployment. per capita income, median household income and racial composition. among other variables. The other major source of demographic data at the county level used in this research is U.S. Bureau of Census' USA Counties 1996: General Profile which summarizes pertinent data on population. housing, education and economic activities.

\section{Maine Land Use}

\section{The Northern Forest}

Klyza and Trombulak. in The Future of the Northern Forest, define the boundaries of the Northern Forest which spreads across Maine. New Hampshire, Vermont and into 
New York. the majority of which lies in Maine. This is a comprehensive source of information on the Northern Forest from the environmentalist perspective. This area is characterized by large continuous tracts of forest, much of it in corporate ownership. sparse population. and traditional use as a recreational and industrial resource. The forest represents an important biological resource noted in The Northern Forest Lands Council Technical Report. due to its biological diversity, which sustains ecosystems.

\section{Ownership}

With regard to land ownership patterns. Klyza and Trombulak (1994) characterizes the portion of the Northern Forest that lies in Maine as large ( 15 million acres), and comprising a center of large industrial and private property ownership. They characterize landowners as falling into four categories. (1) small. local landowners who live year-round on their land; (2) small landowners who use their land as a second vacation home; and (3) large corporate and family landowners who actively harvest and work the land industrially (Klyza and Trombulak 1994). Unfortunately the authors do not provide the proportions that the first two groups comprise of total Northern Forest land ownership. David Dobbs and Richard Ober in The Northern Forest, an anecdotal account of Northern Forest land use, note the dominance of what they describe as "Fortune 500" landowners in the Northern Forest area which include both active and absentee corporate landholders. Knowledge of who owns land in the Northern Forest is very important for this study because the most significant landowners in terms of local voting, will be the small. local landowners who live year-round on their land. The large corporate 
landowners. on the other hand. do not vote directly at the local level but have a powerful influence on local land use and are active lobbyists of the state legislature.

\section{Industrial Land Use Practices}

Most sources agree that Northern Forest land use issues are complex and involve policy questions with economic. ecological, ethical and political dimensions and that there are many differences among representatives of the forest products industries. environmentalists and property rights activists as to how the land should be used. Dobbs and Ober describe present and historical forest products industry land use practices. The most important feature of this account is its description of changes to industrial clearcutting practices since the early eighties, how the public has responded negatively to publicity about clearcutting, and how this stimulated creation of the Maine Forest Practices Act which placed restrictions on clearcutting in 1986.

Klyza and Trombulak (1994) describe the forest products industry harvesting practices that impact the environment as:

- "Cutting and removing trees from large areas" (i.e. clearcutting):

- "Use of heavy machinery in harvesting operations":

- "Herbicide spraying to reduce unwanted tree species";

- "Replanting areas with monocultures of commercially desirable species"; and

- "Repeated cutting at short intervals" (Klyza and Trombulak 1994, 20-21).

\section{Maine Land Use Regulatory Structure}


Another aspect of land use found in the literature are studies and summaries that describe state regulatory frameworks. Various sources. including Pendall. et al in Property Rights and Property Culture and American Planning Association. in Growsmart State Stummaries concur that the State of Maine has a strong presence in the regulation of property. Maine has state level regulations that cover many areas that municipalities may not, particularly in regard to zoning in the numerous unincorporated areas of the state. Both sources describe the various land regulating agencies and programs. and their function.

\section{Land Use Policy Development}

Any recent literature about the Northern Forest at least mentions The Northern Forest Lands Council (NFLC), which was created as a follow up to the Northern Forest Lands Study and work of the Governors' Task Force on Northern Forest Lands. The Council consisted of a stakeholder group charged by Congress in 1990 to study Northern Forest issues and come up with recommendations on how to solve land use conflicts. It was brought together by concern caused by a major land sale by Diamond International Corporation in the late 1980 s that had major implications for future land use for a large part of Maine. The Northern Forest Lands Council, in addressing the complex and intertwined land use, economic. and environmental issues had a strong orientation toward the economic impact of public and private land use decisions. The Council commissioned a great deal of research focusing on the economic influence of the tourism and forest products industry, both reliant on using large areas of the Northern Forest, and the impact of global market conditions on the use of forest land in Maine. The NFLC 
report: Finding Common Ground: Consening the Northern Forest, led to the identification of issues that were seen as running counter to conservation of Northern Forest resources. These issues were used to identify some of the more important research variables that could be used to test hypotheses that might explain the outcome of the 1996 and 1997 referenda, particularly with regard to economic impacts. The issues were also important for developing conclusions on whether a referendum is the most appropriate way to resolve the complex issues identified by the NFLC.

\section{General Background on Referenda and Initiatives}

The initiative and referenda literature ranges widely from broad treatments to analyses of specific ballot issues. and the use of referenda and initiatives for political change in America has a long and complex history. Referenda have been a means for citizen participation in government since colonial times (Schmidt 1989.3). Their use brings up fundamental debate about the roles of representative democracy, as manifested by state and federal legislatures and executive officers, and direct democracy, as manifested by citizen generated initiatives and referenda put on the ballot by legislatures.

There is an important distinction between referendum and initiative described in David Schmidt's Citizen Lawmakers. An initiative is a new idea initiated by citizen petition or by a legislature and, in most states, a minimum number of voter signatures is required for an initiative to be placed on the ballot. A referendum is initiated by citizens or legislators. but must be approved by the legislature before being presented to the public for approval. Common usage has led to referendum and initiative meaning essentially the same thing for most people, i.e. anything put on the ballot for a vote. Most states allow 
their representatives to place referendums on the ballot, but only 23. including Maine. allow citizens. through the petition process, to place initiatives on the ballot (Galvin 1992. 3505). Maine, one of the earlier states to allow initiatives and referenda, voted to put the initiative process in place in 1908 (Schmidt 1989. 16).

Many issues have been presented directly to the public in various states in the form of initiatives and referenda. They have included:

$\begin{array}{lll}\text { Term Limits } & \text { Beverage Container Recycling } & \text { Abortion } \\ \text { Death Penalty } & \text { Limits to Taxation } & \text { Homosexual Rights } \\ \text { Victim's Rights } & \text { Euthanasia } & \text { Tobacco Restrictions } \\ \text { Welfare Limits } & \text { School Choice } & \end{array}$

(Galvin 1992. 3506)

A review of the referendum and initiative literature shows that there is disagreement over the benefits of changing laws through direct votes by citizens. Cronin (1989) summarizes some of the pros and cons of referenda in Direct Democracy: The Politics of Initiative, Referendum and Recall: namely that it makes for a more accountable government, leads to greater citizen participation. creates a better informed electorate, and safeguards against the concentration of political power. He also summarizes what is known about the different media voters get their information from and how media type influences voting decisions. All of the literature seems to agree that. in contrast to partisan candidate election, in referenda. voter decisions are often made in the last few days before the vote.

Summarizing some of the drawbacks of referenda. Schmidt notes that referenda are often vague and poorly written. spending can determine the outcome, they can 
enhance minority rule by serving special interests. access to the ballot is not easy because of the requirement for many signatures, and that there is large potential for deception in

signature drives. Most importantly, he says that a major objection to citizen initiatives is that voters selfishly "vote with their pocketbooks". In other words. they vote for the option they see as giving them the most benefit. Cronin also mentions this phenomenon. seeing it especially where voters are cautious about change. They tend to vote for change only if the benefits to themselves are clear. This observation is very important because it was used as a basis for developing the central hypothesis that people voted on the basis of financial well-being in Maine`s 1996 and 1997 forestry practices referenda.

Some of the pros and cons of initiatives and referenda that have been described by various authors are summarized below (Cronin 1989,61-62 and 207-209. Schmidt 1989. 26 and McManus 1997 20-21):

\section{Summary of Advantages of Initiatives and Referenda}

- Encourages more accountable government: May provoke legislators into action:

- Greater Citizen Participation: Creates perception that ordinary citizens make a difference:

- Sometimes lead to greater voter turnout in elections:

- Better-Informed Electorate: Initiative and referendum campaigns stimulate public debate, making voters more aware of the issues; and

- Safeguard Against Concentration of Political Power: People retain ultimate decision making authority. 


\section{Summary of Disadvantages of Initiatives and Referenda}

- Initiatives poorly written and often unconstitutional: They can't be modified like a bill. and mistakes can be made:

- The side that spends the most money wins: Initiatives and referenda serve special interests. They enhance minority rule because many voters do not vote on them:

- Problems with dropoffs i.e. people vote for the candidates but not for the referendum question(s);

- People unable to vote intelligently on complex issues. not informed or motivated enough to learn about complicated policy issues:

- Process of signature collection for initiatives. which must be done quickly, is not conducive to information dissemination;

- Voters selfishly "vote with their pocketbooks";

- Ballot access for initiatives is not easy, you must be organized enough to get thousands of signatures:

- Signature drive deceptions such as issue oversimplification: For example: "Do you want to avoid environmental catastrophe"; and

- Initiatives and referenda cause a weakening of state legislatures.

\section{Referenda, Initiatives and Campaign Spending}

Many authors have studied the reasons for the success or failure of ballot question campaigns both initiative and referenda. Some, in the specific instance of grassroots versus business interests. have attributed the wealth and organization of business interests against less organized and well financed grassroots groups as being the deciding factor in 
success or failure. One specific case where this occurred was in a vote to shut down the Maine Yankee Nuclear Power Plant in Wiscassett where business interests spent nearly three times more than opponents and won. although by a narrower margin than the spending imbalance would suggest (Lydenberg 1983,53). This is ironic because at least in some places. initiatives, originally viewed as a mechanism by which ordinary citizens could overcome powerful business interests, are now viewed as tools of power and resourceful business interests (Dwyre. et al 1994, 46). Convincing arguments can be made both for and against ballot questions. regardless of how they got on the ballot. and in 27 states without an initiative process the arguments against have prevailed.

\section{Media Influence on Referenda and Initiative Voting}

Campaign spending translates, in large part, to spending on consulting, petition gathering, and actual spots in the print. radio and television media (McManus 1997. 2021). Spending large sums of money by itself doesn't automatically guarantee the outcome of a ballot issue campaign. but it buys resources such as sophisticated public opinion tracking surveys. telephone banks. get-out-the-vote drives, experienced public relations and media consultants, mass mailings and targeted media ads. These resources often provide the edge needed for success in a ballot issue campaign. "So called big money has only about a $25 \%$ success rate in promoting ballot issues... However when big money (usually, though not always, business money) opposes a poorly funded ballot measure. the evidence suggests that the wealthier side has about a 75 percent or better chance of defeating it" (Cronin 1989, 109). 
Media spots can also have the effect of confusing voters, who are more likely to vote against a ballot question if they are unsure of the benefits and uneasy about the risks. They can also have the effect of swinging conditional voters, particularly in the final few day's before an election. which is often when voters decide how they will vote on ballot questions. as opposed to partisan candidate elections (McManus 1997, 20-21). Some sources state that it is easier to defeat a referendum than to win one. and that many voters will adopt an attitude of "when in doubt, vote no" (Cronin 1989. 85).

\section{Correlation Between the Referenda Votes and Economic and Demographic Characteristics of Areas}

In their paper entitled Property Rights and Property Culture: State Property. Rights Bills and the Districts whose Legislators Support Them Pendall. et al use legislator votes on property rights bills to study geographic, socio-economic, and political locations of property culture in various states (Pendall, et. al 1998). This study specifically attempts to find out the clusters of geographic. socio-economic, and political characteristics that correlate with anti-regulatory movements.

In this paper the authors hypothesize that several land-use and ownership characteristics correlate with a district's representative's voting behavior. For instance. a higher proportion of forested land should correlate with support for property rights legislation because it is in these areas that environmental restrictions would be an economic threat and run counter to beliefs about how land should be used. Along these lines. more urban land may contain more residents who wish to retain or strengthen environmental controls, and that this would be reflected in the votes of their 
representatives in the legislature. This study uses a similar approach, with the differences being that the actual vote can be observed rather than the votes of representatives to the state general assembly. which may or may not reflect the majority view of the residents in their districts. The forestry practices ballot questions are similar to property rights bills introduced in the Maine Legislature in that the options involve differing degrees of land regulation. In the case of the forestry practices referenda the options range from banning an important tree harvesting method (clearcutting) to not changing existing regulations. with a compromise option in between. Pendall, et al concluded that the urban-rural distinction is very important, with urban representatives tending to vote against legislation that would give more power to property owners (Pendall, et. al. 1998). The authors also concluded that forest cover was significant in some of the votes. citing an example in Maine.

\section{Findings}

After careful review of the literature relevant to this research, several themes emerged that carry through the rest of this paper. The first theme is the importance of the forest products industry to the state economy in general, the manufacturing sector in particular and to the Northern Forest counties, which are more dependent on these industrial groups than other areas of the State. A sub-theme within the forest products industry is cyclical nature of lumber and paper product production and its dependence on the national and international markets, which tend to have more of an impact on the Northern Forest areas of the state. There also exists strong regional differences in the contribution of non-manufacturing industries to the economy, particularly fishing, 
hunting, hiking and other forest-related recreational activities. In general. most sources emphasize that the economies of the Northern Forest counties are more closely linked to the natural resource base than those in the south and coastal regions. especially the manufacturing sector.

The second theme involves historical and current land uses in the Northern Forest where large corporations and other private landowners control a large portion of the forest resource and where conflicts between uses of the forest have arisen in response to a large land transaction. Many sources devote much attention to defining the Northern Forest which spreads across northern New England and into New York. The literature covering land use of the Northern Forest issues point to the complex economic. ecological. ethical and political dimensions of the debate. Another approach to land use issues is present in a body of literature on state regulations and regulatory structure as it relates to land use controls. The most important of the regulations described in this literature review is the Maine Forest Practices Act. which placed restrictions on clearcutting in 1986.

The third major theme of the literature review described previously are the history and general characteristics of initiatives and referenda, both positive and negative.

This review of the literature also revealed that researchers have observed a correlation between initiative and referendum votes, and economic and demographic characteristics of areas. This is important because making these types of connections is central to the research hypothesis that the results of the 1996 and 1997 were strongly influenced by economic factors. 


\section{Chapter Three}

\section{Maine in Profile}

\section{Introduction}

The purpose of this chapter is to provide the reader with background on the state of Maine and its counties to facilitate an understanding the outcome of 1996 and 1997 referenda. This was done by reviewing the general characteristics of Maine including its geography. land use, demographics, economy, and government, and by applying economic and demographic characterization methodologies. The resulting profiles of both the state and counties set the stage for analysis of the correlation between county characteristics and how these counties voted in the 1996 and 1997 referenda.

\section{Sources of Information}

Many useful and current sources of general information on the State of Maine may be found on the World Wide Web. Some profile the state in a general way, broadly outlining the physical characteristics. government structure, history and major population centers of the state (Brittanica 1998). Others offer a more detailed picture of government activities, including a description of the structure, duties and jurisdiction of the Land Use Regulatory Commission (LURC), an important land use regulatory body that governs the 416 unorganized territories in Maine, mostly in the heavily forested north (Publius 1998 ).

Other useful sources in book form introduce one of the most significant natural features in the state. the so-called "Northern Forest" which is defined by the types of ecosystems it 
contains, by its economic structure. and by regional policymaking (Klyza and Trombulak $199+$ and Dobbs and Ober 1995).

Demographic data aggregated at differing levels of spatial detail are a useful and important source of information for creating profiles of local areas (Myers 1993). Some of the more common types of census data used for profiling include population. household or per capita income. and ethnicity or diversity. This view of the importance of population and its dynamics is particularly relevant for this study because of their potential application for explaining demographic/social factors behind how votes are cast in a certain area. The tendency of census data to be more richly detailed at the regional level than at the local and sub-county level has been noted by some sources and data availability at differing spatial scales is an important factor in the development of analysis methodologies (Myers 1993 and Klosterman 1990).

As for economic analysis of areas. one of the most important steps is the identification of the boundaries of the study: Some of the most useful boundaries are counties and multi-county regions due in large part to the availability of reliable economic data at regular intervals (Klosterman 1990).

Information on employment. a commonly used unit for economic analysis. is obtainable for counties each year in U.S. Bureau of Census County Business Patterns. Payroll is another useful measurement of economic activity because it accounts for things such as overtime and seasonal employment. and can give a rough estimate of an industry's contribution to the local economy (Klosterman 1990). Other types of data are available to measure and compare economic activity of different areas. Value added figures, which avoid double counting of transactions contributing to the local economy, 
are obtained by subtracting a company 's purchases from sales to other business entities. This type of data has useful application to assessing the contribution of the forest product industry to the state economy because it captures some of the "ripple effects" that would be missed by just looking at employment and payroll in County Business Patterns. although this data is often only available at the state level (Klosterman 1990). The Standard Industrial Classification (SIC) system used in the County Business Patterns, a major source of employment and payroll data. codes industrial sectors and major industrial subdivisions in a standardized way that allow's comparison between counties. To protect the privacy of individuals and employers. employment figures are given in ranges where individual employees and employers could be identified using County Business Patterns. Unfortunately this practice makes it difficult to gain accurate employment information on the forest products industry in certain areas (US Bureau of Census 1995. 1998 and Office of Management and Budget, 1987).

\section{Geography}

Maine ranks largest of the six New England states in area with 33.265 square miles, almost half of the total area of New England. The State stretches 320 miles lengthwise and 210 miles in width, containing 2.270 square miles of inland water composed of 2,500 lakes and ponds, numerous rivers, and a 3,500 mile saltwater coastline. The Canadian provinces of Quebec and New Brunswick define the northwest and northeast boundary of the state respectively, with the state of New Hampshire forming the State's western border, and the Atlantic Ocean defining the southern and eastern border. The western and northwestern borders adjoining New Hampshire and 
Quebec have the most mountainous geography. with many peaks. lakes, and valleys of the Appalachian mountain chain. To the south and east of the Appalachian mountains, hills and smaller mountains separate the valleys of the major rivers: the Saco. Androscoggin. Kennebec. and Penobscot. The Appalachian Mountains extends into Maine from New Hampshire with Mount Katahdin. at 5.268 feet. the state's highest elevation. The Atlantic coastline of the state runs from southwest to northeast with many rocky indentations (Figure 3.1). Forests cover nearly 90 percent of the state. with extensive stands of pine. spruce. and fir among the softwood species and sugar maple. yellow birch, aspen. and paper birch among the hardwoods (Brittanica. 1998). The forests of the northern two thirds of the state continue into northern New Hampshire. Vermont and New York and comprise a major part of what is known as "The Northern Forest" (Klyza and Trombulak 1994, 12). 
Figure 3.1

\section{Topographic Areas}

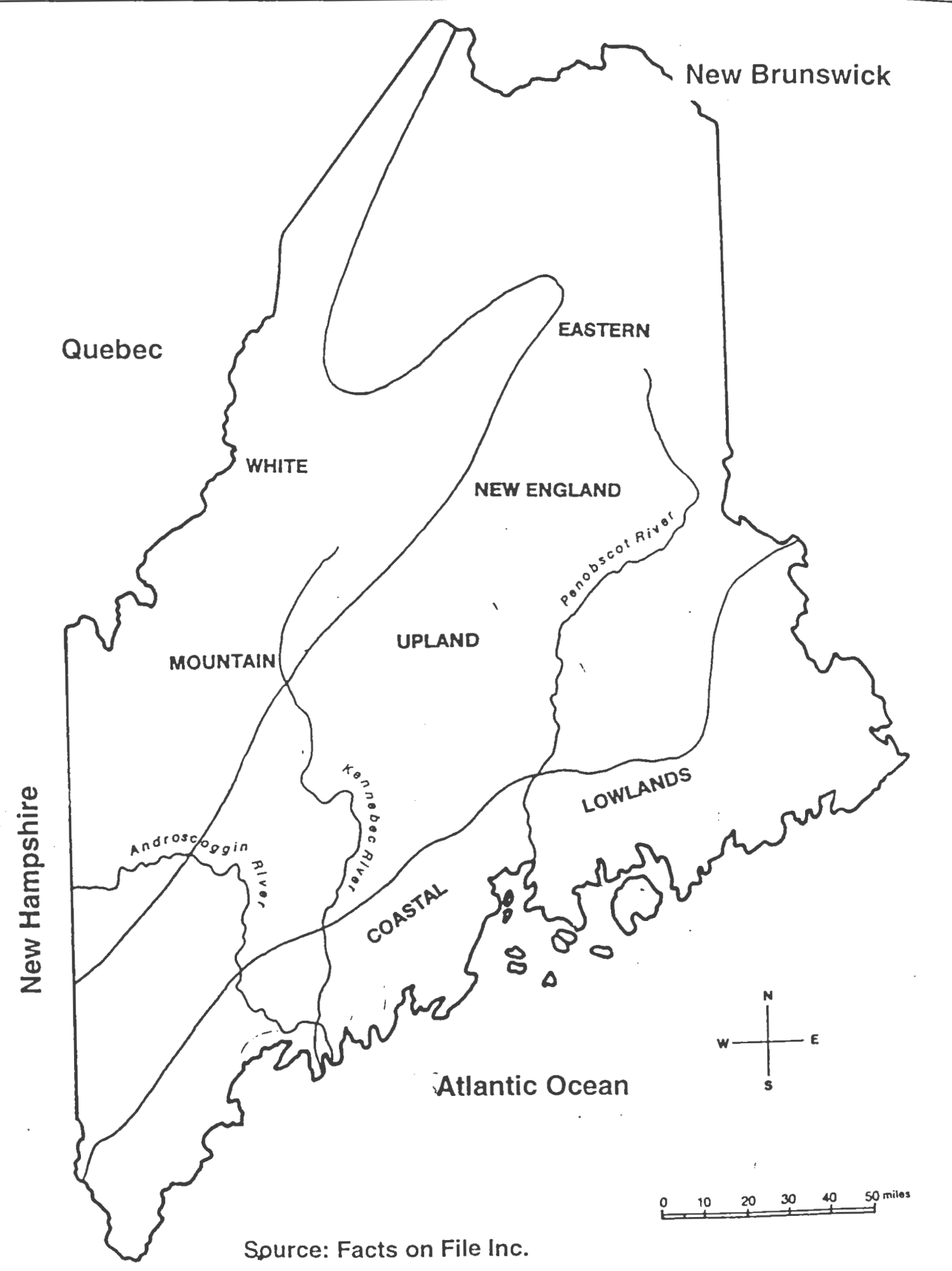




\section{Overview of Maine Forest Land Use and Ownership}

In total. Maine contains 17.5 million acres of woodlands representing 90 percent of its total land area. This vast forest cover makes it the most heavily forested state in the nation. Almost half of the forest acreage. 8.1 million acres, is owned by eight large paper corporations, sawmills and other manufacturing concerns. This gives Maine the highest concentration of "industrially-owned" forest in the country. Industrial ownership refers to companies that own manufacturing facilities, including pulp and paper product mills. Large "non-industrial" landowners who sell wood to the forest products industry own another 3.1 million forest acres in tracts larger than 5.000 acres. "Approximately one hundred thousand small landowners control 5.4 million acres, and the rest. 900.000 acres. is publicly owned - at 5 percent, the smallest percentage of public land in the Northeast" (Dobbs and Ober 1995 117-118. Irland 1995. 13 and Table 3.1). Land ownership in the southwestern and coastal areas. where the large majority of the state's population reside. tends to be more fragmented. the commercial woodlots tend to be smaller, and residential uses consume more of the land area. The 1993 Northern Forest Lands Survey of Woodlot Ownership considers a smaller area as woodland than Dobbs and Ober or Irland but provides a helpful illustration of these land use patterns when represented spatially (Figure 3.2). With such large landholdings, large forest products companies are a major force in the management and ultimately the character of much of Maine's forested areas (Klyza and Trombulak 1994,36). Agriculture in contrast, only accounts for $7.6 \%$ of total private land usage, following a trend of decline for at least a decade (CBER 1998. Table 1.1.4). 


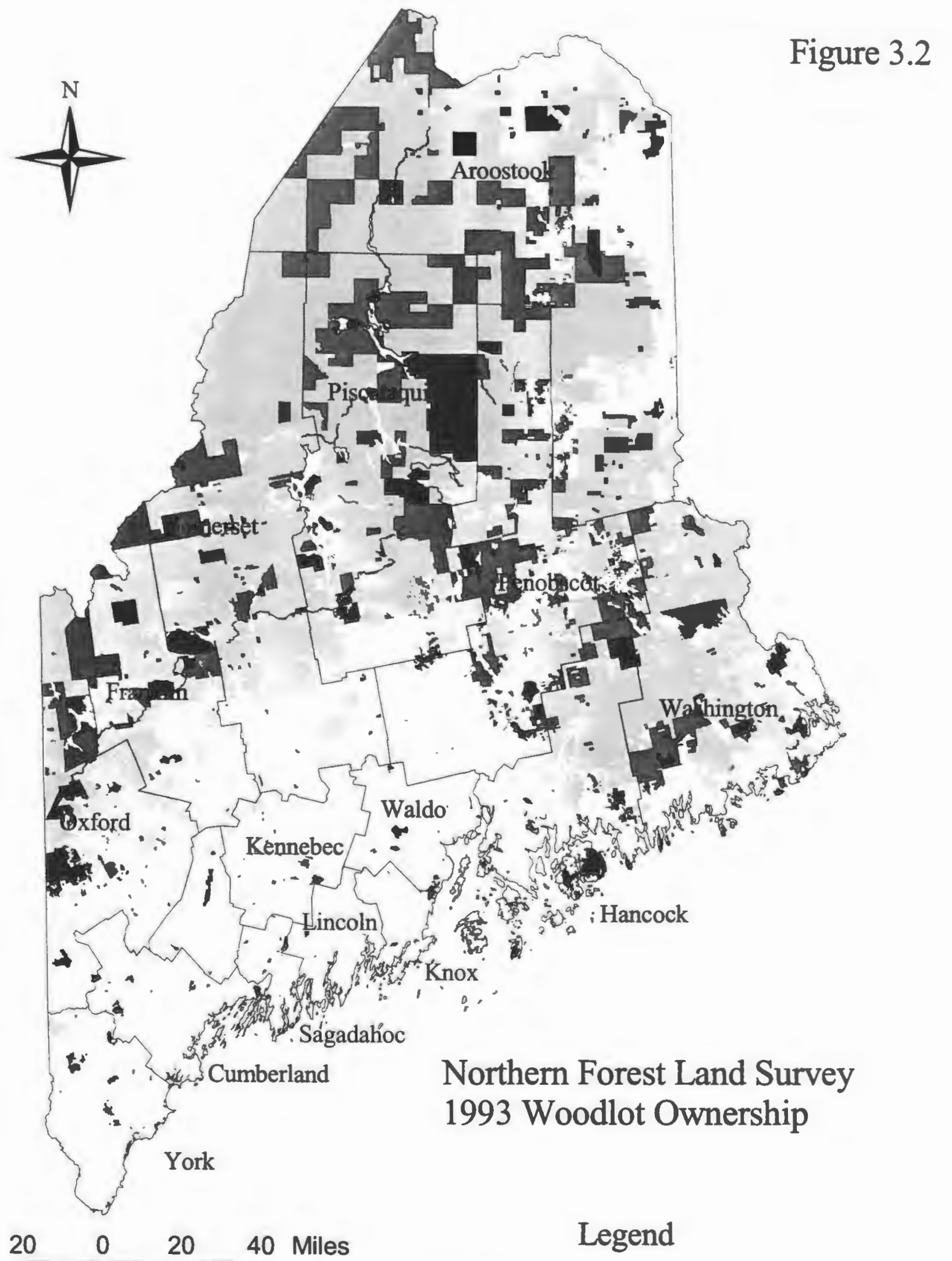

Ownership Type $\quad$ County Boundaries

Source: Maine Office of Geographic Information and J.W. Sewall Co.

\begin{tabular}{l}
\hline$\quad$ Non-Woodlot \\
Industrial (having at least 1 wood processing facility) \\
Non-Industrial (having no wood processing facilities) \\
Public (local, state and federal)
\end{tabular}


The Northern Forest provides the raw materials which power the forest products industry, a large presence in the state. regional and local economies. and the management of timberlands is closely tied to the global economy, which experiences cycles of demand for forest products. The Northern Forest also provides a place for recreational activities, which also makes a significant contribution to the economy at different geographic scales. At the same time, this area is prized by conservationists for its large contiguous tracts of relatively intact forest. The above described situation has resulted in competing and conflicting uses of the Northern Forest. Government at the federal state and local level struggle to balance conflicts between timber harvesting. recreation and conservation activities which are in turn influenced by complex social and economic forces (Klyza and Trombulak 1994. 66).

Table 3.1: Maine Land Ownership, 1994 (millions)

\begin{tabular}{|l|c|c|}
\hline Owner & Acreage & Percent \\
\hline Total Public & 0.9 & 5.1 \\
\hline & & \\
\hline Industrial (8 Large Corporations) & 8.1 & +6.3 \\
\hline Private Non-industrial $(>5.000$ acre tracts) & 3.1 & 17.7 \\
\hline Private Non-industrial $(<5.000$ acre tracts) & 5.4 & 30.9 \\
\hline Total Private & 16.6 & 94.9 \\
\hline & & \\
\hline All Woodlands & 17.5 & 100 \\
\hline
\end{tabular}

(Dobbs and Ober 1995, 117-118) 


\section{Demographics}

Maine's 1997 population stood $1.22+$ million, a $-0.3 \%$ change from 1990 when the population was 1.228 million, and even lower than the 1980 population of 1.125 million. Its population is forecast to increase $6.3 \%$ to 1.301 million by 2006 (Table 3.2).

\section{Table 3.2 Maine Population and Population Growth}

\begin{tabular}{|l|c|c|c|c|c|c|c|}
\hline & \multicolumn{3}{|c|}{ Historical Levels } & \multicolumn{3}{c|}{ Forecast } & \multicolumn{3}{c|}{ Percent Change } \\
\hline Region & $\mathbf{1 9 8 0}$ & $\mathbf{1 9 9 0}$ & $\mathbf{1 9 9 7}$ & $\mathbf{2 0 0 6}$ & $\mathbf{1 9 9 0 / 1 9 8 0}$ & $\mathbf{1 9 9 7 / 1 9 9 0}$ & $\mathbf{2 0 0 6 / 1 9 9 7}$ \\
\hline Maine & 1.125 .043 & 1.227 .928 & 1.224 .069 & 1.301 .473 & $9.1 \%$ & $-0.03 \%$ & $6.3 \%$ \\
\hline New England & 12.348 .493 & 13.206 .943 & - & - & $7.0 \%$ & - & - \\
\hline United States & 226.546 .000 & 248.762 .000 & - & - & $9.8 \%$ & - & - \\
\hline
\end{tabular}

(CBER 1998. Figure 1.2.2)

Maine's retirement age (65+) population made up 13.3 percent of the 1996 state population, a percentage that is expected to increase as the population ages. Maine ranked eleventh in the nation in the $65+$ category, over the national average of 12.8 percent.

Maine's 1996 population was overwhelmingly white and non-hispanic with less than $2.2 \%$ of the population classified in non-white categories as compared to $19.7 \%$ for the nation (CBER, 1998 Figure 1.2.6).

Median household income stood at $\$ 28.732$ in 1993 , but the rate of increase in the 1990s has lagged behind the country's (CBER 1998). Historically, Maine has a lower median household income than New England or the country as a whole. Maine's 1989 median household income was \$27.854 while New England's was \$36.241 and United States' was $\$ 30,056$ (CBER 1998 p.1.2.10). 
Roughly half of Maine's 1.24 million population reside in four southwestern counties: Androscoggin. Cumberland. Kennebec, and York; almost half of Maine's residents live in urban areas (Figure 3.3). Despite this concentration of the population. only 11 cities contain 25.000 or more inhabitants. The largest of Maine's urban communities are Portland. Lewiston-Auburn. Bangor. Augusta, Biddeford. and Waterville. Portland, located on the southern coast. lies at the center of a metropolitan area that serves as the commercial and transportation hub for the state (Brittanica 1998). The adjacent cities of Lewiston and Auburn. in the southwest hills area. together comprise the second largest urbanized area in the state after metropolitan Portland. Bangor, originating as a lumber town on the Penobscot River, is the commercial center for eastern and northern Maine. The capitol city of Augusta lies on the Kennebec River in the south central of the state. With its location just north of the Boston-Washington metropolitan area. Maine is located in relatively close proximity to a significant portion of the nation's population. Maine's overall population density was 37 persons per square mile in 1995 (CBER 1998).

The 1995 civilian labor force. excluding government and agricultural employment. stood at 591,693 workers. The state's labor force experienced a similar unemployment to the country and the region, with $5.7 \%$ of the workforce unemployed compared to $5.6 \%$ for the country and 5.5\% for New England, and a relatively low per capita income of $\$ 18,780$ in 1993 , the latest year for which these data are available (CBER 1998, 1-5). 


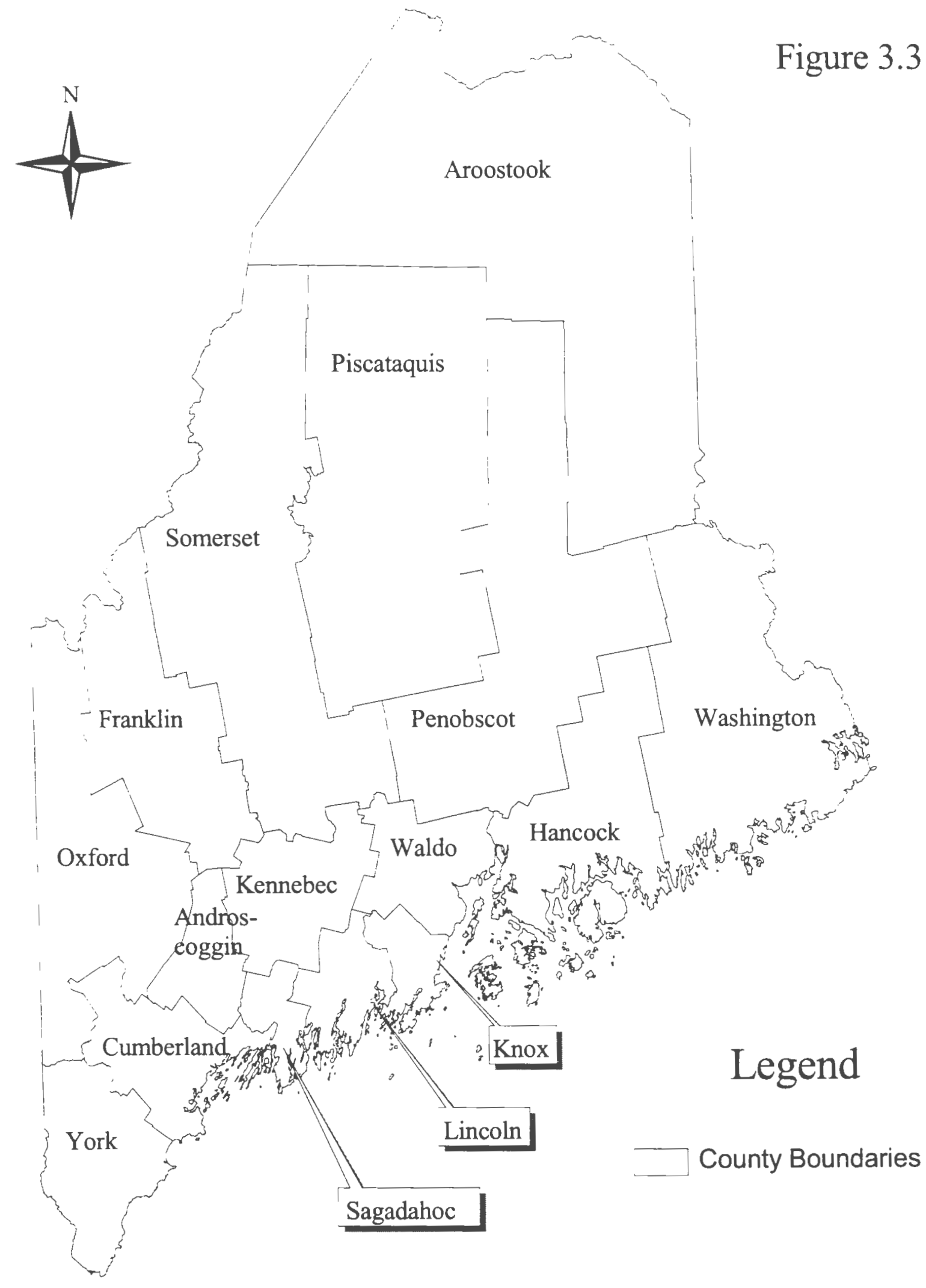

$\begin{array}{lllll}20 & 0 & 20 & 40 & \text { Miles }\end{array}$

Maine Counties 


\section{Economy}

The following section on Maine and subsequent sections on individual counties within the state is. in large part, based on the US Bureau of Census Standard Industrial Classification System (SIC) used in County Business Patterns. This system is useful for creating basic economic profiles for small areas and for examining the economic structure of regions when aggregated. County Business Patterns data include figures for employment. payroll and number of establishments by employment size classes. While useful. it overlooks some economic sectors, or basic business types. that may be important in some areas. Notably, the SIC system does not cover self-employed persons. domestic service workers, and most government employees (US Bureau of Census 1998. 1). For example. these omissions may skew the figures in counties such as Kennebec. which contains the capitol city of Augusta, and where state government would be a significant employer with a large contribution to the county's economy, or in some of the coastal counties with large tourist industries, and thus many self-employed workers. However. since the focus of this paper is on the forest products industry. which is covered under the SIC manufacturing sector category and more detailed major groups, these shortcomings will be overlooked for this research. The following table shows the most basic SIC divisions, or sectors, and some specific major groups related to the forest products industry used in this paper to characterize the economy of individual counties (Table 3.3). 
Table 3.3: SIC Sectors and Major Groups

\begin{tabular}{|l|}
\hline \multicolumn{1}{|c|}{ SIC Sectors and Major Groups } \\
\hline 07: Agricultural Services, Forestry and Fishing \\
\hline $0800:$ forestry \\
\hline 10: Mining \\
\hline 15: Construction \\
\hline \\
\hline 20: Manufacturing \\
\hline 2400: lumber and wood products \\
\hline 24l0: Logging \\
\hline 2600: paper and allied products \\
\hline \\
\hline 40: Transportation and Public Utilities \\
\hline 50: Wholesale Trade \\
\hline 52: Retail Trade \\
\hline 60: Finance, Insurance and Real Estate \\
\hline 70: Services \\
\hline 99: Unclassified Establishments \\
\hline
\end{tabular}

Under the manufacturing sector, the major group lumber and wood products... "includes establishments engaged in cutting timber and pulpwood: merchant sawmills. lath mills, shingle mills. cooperage stock mills, planing mills, plywood mills, and veneer mills engaged in producing lumber and wood basic materials: and establishments engaged in manufacturing finished articles made entirely of wood or related materials" (Office of Management and Budget 1987, 107). Another major group of interest. Logging. which is a sub-category of lumber and wood products, includes... "establishments primarily engaged in cutting timber and in producing rough, round. hewn, or riven primary forest or wood raw materials, or in producing wood chips in the field." This major group doesn't include activities such as the trucking of timber or maple sugaring (Office of Management and Budget 1987, 107). The major group paper and allied products 
includes... "establishments primarily engaged in manufacturing pulp from wood or from other materials. such as rags. linters, wastepaper. and straw" (Office of Management and Budget 1987, 119). Together these major groups cover most of the forest products industry's activities with the exception of trucking. In 1995 Maine's entire manufacturing sector, which includes the major groups described above. accounted for 20.9 percent of state employment and 27.3 percent of payroll. The lumber and wood products. and paper and allied products groups made up 12.7 and 15.2 percent of state manufacturing employment respectively, although they represented less than $6 \%$ of the overall state employment. These figures belie the fact that when ranked by the value of the products produced. the paper and allied products major group alone ranked first by far among manufacturing industry groups in value of product produced at $\$ 3.7$ billion (Haugen 1996, 2).

Forest-based industries covered under these major groups have increased their share of manufacturing production in Maine since 1905 during a time when manufacturing's share of total employment has declined. This runs counter to normal economic growth where the share of resource-dependent industries shrinks as other nonresource-dependent industries grow. This is due to productivity increases in the forest products industry (Irland 1998, 19). Lumber and paper product production tends to be cyclical depending on demand in the national and international markets. "From 1986 to 1991, fully half of the increase in Maine's manufacturing output was due to increases in lumber and paper sales volumes. In 1992, the top three employers in manufacturing were paper (16.489), transportation equipment (mostly shipbuilding) (13.067), and lumber and wood" (10.794) (Irland. 1998 p.19). In 1992 the average hourly earnings in the pulp and 
paper industries was $\$ 16.25$ versus $\$ 11.38$ for all manufacturing and $\$ 9.25$ for lumber and wood products industries (Irland. 1998 p.19).

The economies of the Northern Forest counties (Oxford, Franklin. Somerset. Piscataquis. Aroostook. Penobscot, Hancock and Washington) are more closely linked to the natural resource base than those in the south and coastal regions. especially the manufacturing sector. The timber resources of these northern counties provide the primary input for the forest products industry. Large paper mills, many owned by multinational corporations, process the region's trees into products such as regular white paper. newspapers. specialty papers. and cardboard boxes. More numerous sawmills cut logs into lumber products that are used for home construction. kitchen cabinets and furniture (Klyza and Trombulak 1994. 52).

Maine's unemployment has shown greater variation than that of New England but in general, the southern portion of the state has experienced unemployment levels significantly lower than the rest of the state.

The service sector dominates Maine's economy, providing one out of every three jobs based on 1995 data. The health services major group leads the service sector. accounting for almost half of the service employment (Figure 3.4 and Table 3.4). Retail trade accounts for roughly one quarter of state employment led by eating and drinking establishments and food stores, common staples in any economy. The rest of the major standard industrial classes listed in table 3.4 contain the remainder of the state's jobs, with no sector accounting for more than $6 \%$ of the total (CBER 1998). 
Figure 3.4

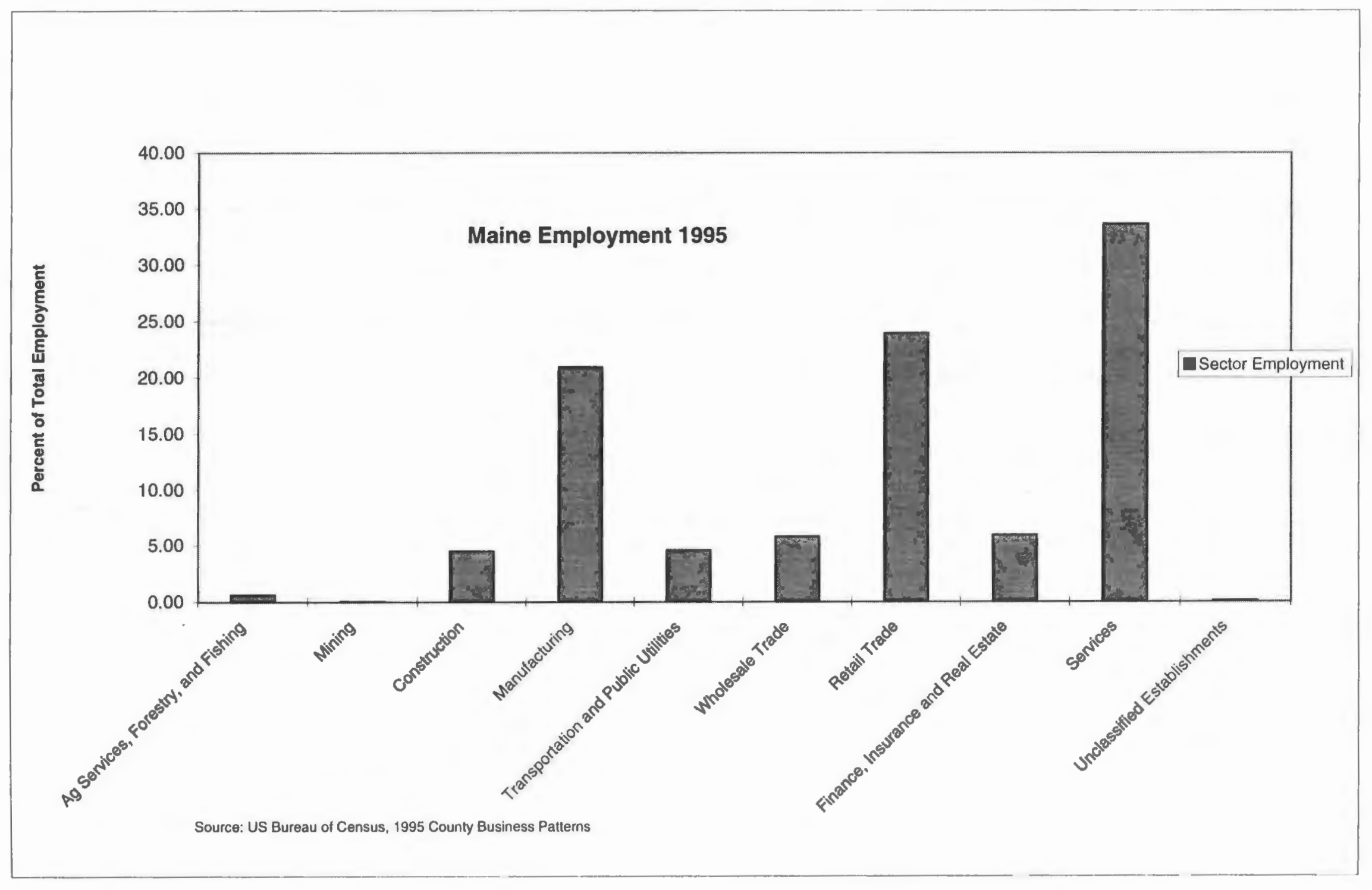


Table 3.4: Maine Employment 1995 by Sector

\begin{tabular}{|c|c|c|c|c|c|c|}
\hline & SIC Codes and Category Titles & "Employees & $\begin{array}{l}\text { *Annual Payroll } \\
\text { (Dollars) }\end{array}$ & $\begin{array}{l}\text { Employment as } \\
\% \text { of state total }\end{array}$ & $\begin{array}{l}\text { Payroll as } \\
\% \text { of state total }\end{array}$ & $\begin{array}{l}\text { Employment Percent of } \\
\text { Manufacturing Sector }\end{array}$ \\
\hline \multirow[t]{15}{*}{ Maine } & 07: Ag Services, Forestry, and Fishing & 2,637 & $56,510,000$ & 0.6 & 0.6 & \\
\hline & 0800: forestry & 270 & $6,020,000$ & 0.1 & 0.1 & \\
\hline & 10: Mining & 67 & $1.670,000$ & 0.0 & 0.0 & \\
\hline & 15: Construction & 19,384 & $539,360,000$ & 4.5 & 5.5 & \\
\hline & 20: Manufacturing & 90,548 & $2,678,200,000$ & 20.9 & 27.3 & \\
\hline & 2400: lumber and wood products & 11,521 & $254,660,000$ & 2.7 & 2.6 & 12.7 \\
\hline & 2410: Logging & 3,444 & $76,050,000$ & 0.8 & 0.8 & \\
\hline & 2600: paper and allied products & 13,726 & $635,770,000$ & 3.2 & 6.5 & 15.2 \\
\hline & 40: Transportation and Public Utilities & 19,767 & $564,330,000$ & 4.6 & 5.8 & \\
\hline & 50: Wholesale Trade & 25,020 & $682,310,000$ & 5.8 & 7.0 & \\
\hline & 52: Retail Trade & 103,469 & $1,464,270,000$ & 23.9 & 14.9 & \\
\hline & 60: Finance, Insurance and Real Estate & 25,568 & $751,970,000$ & 5.9 & 7.7 & \\
\hline & 70: Services & 145,448 & $3,053,370,000$ & 33.6 & 31.2 & \\
\hline & 99: Unclassified Establishments & 382 & $8,240,000$ & 0.1 & 0.1 & \\
\hline & Total & 432,290 & $9,800,270,000$ & 100.0 & 100.0 & \\
\hline
\end{tabular}

Source: US Bureau of Census: 1995 County Business Patterns 


\section{Government}

Maine, the nation's 23rd state. entered the union in 1820 after existing as a territory of the State of Massachusetts. Its government operates from the capital city of Augusta in the south-central region. The governor. Maine's chief executive officer, works under a checks and balances system with the House of Representatives and Senate. The Governor serves a term of four years. with a two-term limit (Brittanica, 1998). The Maine Legislature consists of part-time citizen representatives and senators. One hundred and fifty one Representatives elected for a two-year term may serve up to 4 consecutive terms. Currently, members of the Maine House represent approximately 7.500 people in a district. Thirty five Senators elected for a two-year term may serve up to + consecutive terms. Currently, members of the Maine Senate represent approximately 32.000 people in a district (Maine 1998, 1). In 1996 the count of registered voters in Maine stood at 936,793 (Publius 1998. 1-2).

Maine's judicial branch of government operates at three levels. including district judges, a superior court. and a supreme court. The sixteen counties provide the governmental structure for the superior court system, law enforcement, and land records. Counties are also responsible for some road maintenance and construction functions, however as is typical of New England states, county government is relatively weak compared to southern and western states, and many land-use regulatory functions such as zoning are performed at the municipal level (Brittanica, 1998).

Incorporated town government typically consists of a board of selectmen who conduct annual town meetings, but some of the larger communities are run by a 
professional manager and operate under a city charter. On the local level. Maine contains 424 towns, 51 plantations. and +16 unorganized territories. The Maine Land L'se Regulation Commission. known by the acronym "LURC" acts at the state level as the planning and zoning authority for the state's +16 unorganized territories. LURC's

jurisdiction generally coincides with the area of the state where larger private landholders predominate (Publius 1998. 6 and Figure 3.5). Most of the unorganized territories are found in the more remote regions of the state, particularly in the northern two thirds. The Commission consists of seven members who develop land use policy and make land use decisions such as rulings on zoning petitions and rulings on large, precedent-setting or complex applications. The Commission also approves enforcement actions (LLRC 1998).

\section{State Land Use Regulatory Structure and Policy Development}

The State of Maine exercises a strong presence in the regulation of private property directly through regulations. and indirectly through policy and policy development (Growsmart 1996. 1). This section will discuss the policy and regulatory aspects of land use in Maine that relate to the Northern Forest, and to the 1996 and 1997 forestry practices referenda. This analysis will also briefly describes attempts by the Northern Forest Lands Council to develop and implement land use policy to guide management of the Northern Forest. 


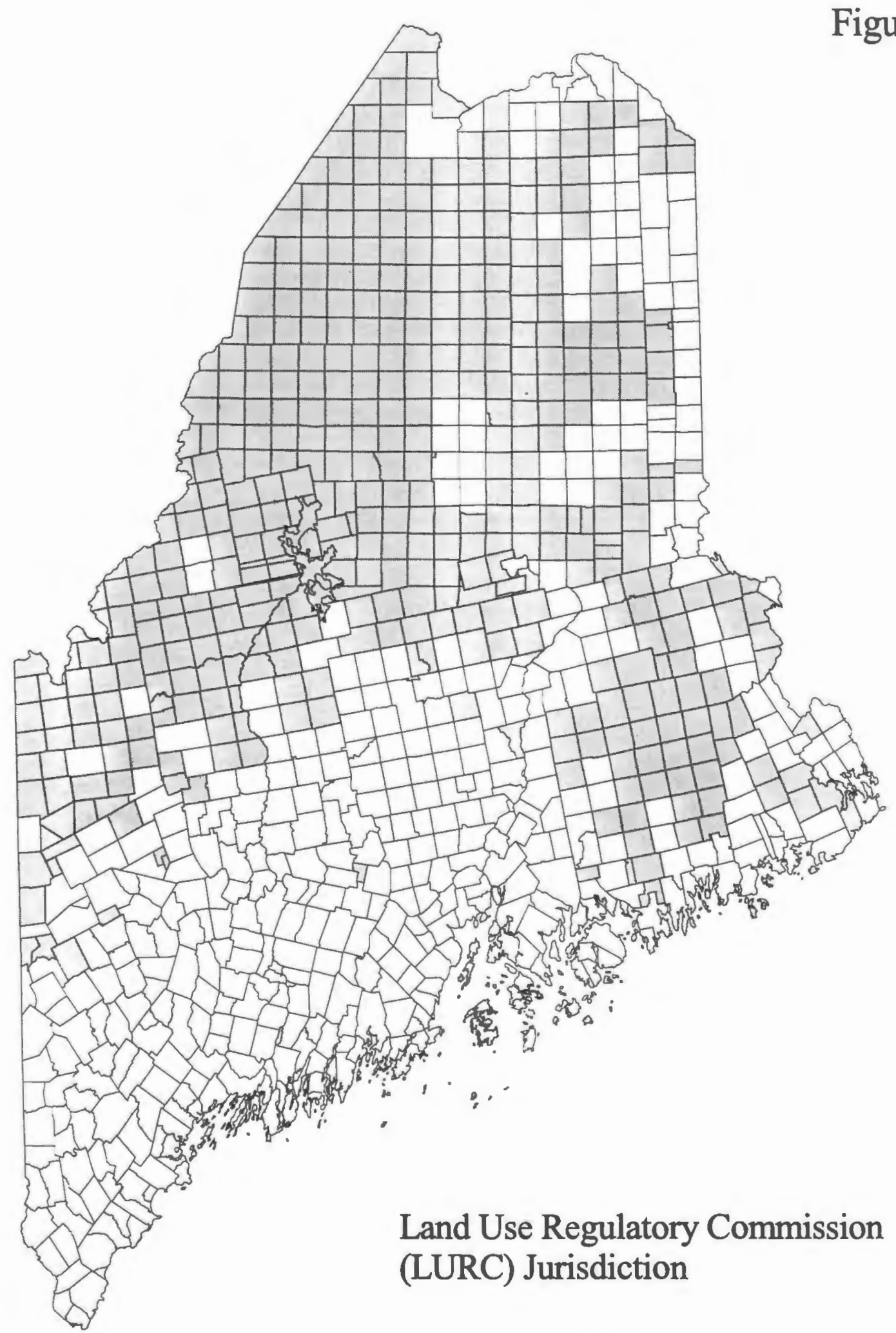

Figure 3.5 


\section{General Overview of Maine's Regulatory Structure}

At the direct regulation level. the Department of Environmental Protection (DEP) exercises considerable power over land use and planning through the Site Location of Development Law. which requires a permit for developments with potential for substantial impact on the environment. This law covers any development that occupies more than 20 acres and subdivisions, structures. mining. or excavation of natural resources with an area greater than 60,000 square feet. The DEP also has the power to regulate dredging and filling of coastal wetlands (Growsmart 1996, 2). U.S Army Corps of Engineers and the U.S. Environmental Protection Agency also regulate certain types of wetland alteration (Irland 1995. 77 and Table 3.5).

\section{Table 3.5: Regulations affecting forest landowners in the State of Maine's Northern} Forest

\begin{tabular}{|l|l|}
\hline Regulation & Administering Agency \\
\hline Subdivision of Development & $\begin{array}{l}\text { Land Use Regulatory Commission (LURC) } \\
\text { Department of Environmental Protection }\end{array}$ \\
\hline $\begin{array}{l}\text { Cutting in Protection Zones } \\
\text { and Deer wintering Areas }\end{array}$ & $\begin{array}{l}\text { LURC, in consultation with Inland Fish and } \\
\text { Wildlife }\end{array}$ \\
\hline Road building. Stream Alterations, Sedimentation & LURC. EPA \\
\hline Wetlands alteration & Corps of Engineers (general permit). EPA \\
\hline Fire Safety Practices & Maine Forest Service \\
\hline Regulated Cutting Practices & Maine Forest Service \\
\hline Cutting in Allagash One Mile Corridor & Bureau of Parks and Recreation \\
\hline $\begin{array}{l}\text { Management Plan Requirement } \\
\text { Tree growth tax }\end{array}$ & Bureau of Taxation \\
\hline Eagle Nests/Endangered Species & U.S. Fish \& Wildlife Service \\
\hline
\end{tabular}

Source: Irland 1995.77 
The Land Lise Regulation Commission (LURC or "the Commission"), which falls under the Maine Department of Conservation, provides planning. zoning and development approvals for the unincorporated territories in the state (Growsmart 1996. 1). The Commission. created by the State Legislature in 1971. serves as the planning and zoning authority for the state's unorganized territories. which lack any municipal government. It also functions as the policymaking body for these areas. It was established in the 1960's in part as a response to concerns about a surge of recreational and other types of land development in the unincorporated regions. Its authority and purpose derive from the police powers of the state to regulate land use to preserve public health, safety, and welfare. Other purposes of LURC's authority include encouragement of planning for the multiple use of natural resources and promotion of orderly development. More specifically. LURC's responsibilities include setting policy. adopting new rules and rule changes, acting on zoning petitions and large. precedent-setting or complex applications. and approving enforcement actions (LURC 1998, 1).

Much of the state-level regulatory presence concerns residential and not commercial timberland uses. which are prevalent in the Northern Forest region. Many of the regulations do not apply unless the timberland is sold for subdivision. However, the Maine Department of Conservation's Maine Forest Service is responsible for implementing the Forest Practices Act, which regulates clearcuts and other forestry practices (Table 3.5 ). Its provisions include:

- Standards for tree regeneration;

- Performance standards (e.g. maximum clearcut size - 250 acres):

- Harvesting plans required for clearcuts over 50 acres: 
- Provisions for variances: and

- Provisions regarding transfer or sale of property (Maine Revised Statutes 1997)

\section{Local Land Use Regulation}

The state allows, but does not require, municipalities to adopt comprehensive plans and growth management programs. which must be enacted by the municipal legislature to be recognized as valid (Growsmart 1996, 4). Cities and towns may adopt zoning ordinances and land use controls, including timber harvesting practices, and these must also be enacted by the municipal legislature to be valid. State law mandates that the zoning ordinance be consistent with the comprehensive plan. if one exists. The state also mandates zoning and land use controls in shoreline areas (Growsmart 1996, 4-5).

\section{Maine's Land Use Policy-Making Agencies}

Various offices of state government serve in different roles in land use policy development. The state planning office, while not a directly regulatory agency. creates comprehensive resource management plans for rivers and coastal areas and create reports on state agency compliance with the plans. Similarly, the Land and Water Resource Council, comprised of certain department heads and the Planning Office Chief. advise the

Governor, legislature and the relevant departments on coordination of state policy on land use and management issues (Growsmart 1996, 1). 


\section{The Northern Forest Lands Study and the Northern Forest Lands Council}

The Northern Forest Lands Council serves as a strong, if controversial. influence on Maine land use policy dealing with the Northern Forest. In 1986 conservation and forestry leaders, including representatives from International Paper and the Maine Forest Products Council created a "Forest Forum" which included industrial, academic. environmental and government interests. This forum led to creation of the Maine Forest Practices Act (the Act). The Act. outlined previously, involved restrictions on clearcutting, stricter reporting requirements for logging activities and additional stafting for the Maine Forest Service. "According to landowner reports compiled by the Maine Forest Service, 59.602 acres were clearcut in 1992. or 12 percent of the land that was harvested in some manner" (Dobbs and Ober 1995, 127). The Northern Forest Lands Council's stated orientation was toward maintaining the traditional patterns of land ownership in the entire multi-state Northern Forest region. The Council intended to achieve this mission through:

- Promotion of economic stability through the maintenance of large forest areas:

- Encouraging forest management that produces a sustainable yield of forest products: and

- Protection of recreational, wildlife. scenic, and wildland resources (The Northern Forest Lands Council 1994, Inside cover).

Created in 1990 with 17 stakeholders and stakeholder groups including governors of the four Northern Forest states and one USDA Forest Service representative, the Council conducted a study to determine Northern Forest issues and come up with 
recommendations through a public process (The Northern Forest Lands Council 1994. 5). Public participation included representatives of landowners, property rights interests. environmental interests, timber industry, academia. recreation, tourism businesses, and communities (The Northern Forest Lands Council 1994, 6). The report identified numerous conditions that threatened conservation of Northern Forest resources:

- Increasing polarization among forest user groups:

- Rising property taxes, causing loss of land from natural resource uses:

- Pressure for development of high-value areas near shorelines and scenic places:

- Jobs lost to competition from other regions and countries:

- Incomplete knowledge of land management techniques to maintain or enhance biological diversity;

- Lack of funding and clear priority-setting for public land and easement acquisition:

- Insufficient attention to and funding for public land management:

- Fear of losing public recreational opportunities and access to private lands;

- Loss of respect for the traditions of private ownership and uses of private land; and

- Failure to consider forest land as a whole, as an integrated landscape (Northern Forest Lands Council 1994, 11-12).

The NFLC made the following specific recommendations to address these issues:

- Change tax structure away from taxation for highest and best use (i.e. development) and toward current value and current use; 
- Encourage sustainable forest management through education and an assessment of forest practices and programs impacts:

- Increase funding for public land management agencies geared towards land acquisition planning programs; and

- Encourage market cooperatives, networks. and direct assistance to natural resourcebased businesses.

These policy recommendations and the regulations discussed previously are the backdrop for the struggle of various public and private groups representing diverse interests for a say in how land is used in the Northern Forest. 


\section{Maine Counties in Profile}

Similar to the previous section which profiled the demographics of Maine's population and Maine's economy, this section will profile each of the state's sixteen counties. These profiles make comparisons between individual counties and the state as a whole as well as comparisons between individual counties. The purpose of this section is to point out the important characteristics of the counties that can be examined for correlation with voting patterns in the 1996 and 1997 forestry practices referenda.

\section{Androscoggin County}

Androscoggin County ranks thirteenth among counties in land area with 497 square miles. The 1995 population of roughly 100,000 persons has increased only 4.1 percent since 1980 and decreased a half a percent since 1990. reflecting a decreasing rate of population growth in the county over the last five years. The County ranks second in population density with 209 persons per square mile, a reflection of the presence of the Lewiston-Auburn metropolitan area. Androscoggin County contains an average percentage of residents over the retirement age of 65 at $14 \%$. Its residents have achieved an education level well below the state average of 78.8 , with only $71.8 \%$ of the age 25 and older population having earned a high school diploma or equivalent and 13 percent having earned a college degree. The 1994 civilian labor force stood at 54.835 workers ranking fifth in the size of its county labor force. The county's labor force experienced an unemployment rate of $7.5 \%$ and a per capita income of $\$ 18.286$ in 1993. about average for the state (CBER 1998 and Table 3.6). 
The service sector accounts for $36 \%$ of Androscoggin county's total employment of 39.431 followed by retail trade which accounts for another approximately one third. Manufacturing made about a quarter of the county's 1995 employment ( 9.411 workers). Of this figure the lumber and wood products and paper and allied products together account for about $15 \%$ of the manufacturing jobs. None of the sectors make up more than $5 \%$ of employment (Appendix A).

\section{Aroostook County}

Aroostook County, the northernmost county, ranks first among counties in land area with 6.819 square miles. The 1995 population of roughly 78.000 persons has decreased 16.6 percent since 1980 and 10.6 percent since 1990, reflecting a population decrease which has accelerated over the last five years. Aroostook County ranks second to last in population density with 12 persons per square mile. far below the 37 person per square mile average for the state. Aroostook County contains slightly more than average percentage of residents over the retirement age of 65 . Its residents have achieved some of the lower education levels in the state education level, with $70.9 \%$ of the age 25 and older population having earned a high school diploma or equivalent and 12.5 percent of the same population having earned a college degree. The 1994 civilian labor force stood at 37,944 workers. The county's labor force experienced the second highest unemployment rate in the state at $11.7 \%$ and the highest per capita income of $\$ 15.238$ in 1993 (CBER 1998 and Table 3.6).

The service sector accounted for about a third of Aroostook County's total employment of 22.624 workers in 1995 , retail trade. $25 \%$, and manufacturing $21 \%$. Of 
the manufacturing employment the lumber and wood products contributes $42 \%(1.969$ workers) and paper and allied products a $37 \%$. indicating the significance of the forest products industry in this county. These figures are based on estimate for paper and allied products. The remaining employment is mainly accounted for by the transportation and public utilities, the rest being under 5\% (Appendix A).

\section{Cumberland County}

Cumberland County, located in the southwest coastal region, ranks eleventh among counties in land area with 915 square miles. The 1995 population of roughly one quarter million persons increased at an overall rate of 13.2 percent since 1980 but only 2.2 percent since 1990, reflecting a decreasing rate of population growth in the county over the last five years. although it is one of the faster growing counties in the state. Cumberland County ranks first in population density with 272 persons per square mile. far above the 37 person per square mile average for the state. This is not surprising for one of the smaller counties containing the largest metropolitan area in the state. which includes the city of Portland. Cumberland County contains fewer than most counties in residents over the retirement age of 65 , ranking near the bottom $\left(14^{\text {th }}\right)$. Its residents have achieved the highest education level, with $85 \%$ of the age 25 and older population having earned a high school diploma or equivalent and 27.6 percent having earned a college degree. The 1994 civilian labor force stood at 125.102 workers, by far the most of any county. The county's labor force enjoyed the second lowest unemployment rate in the state at $5.1 \%$ and the highest per capita income of $\$ 23,063$ in 1993 (Table 3.6). Median household income stood at \$35,086 in 1993 (CBER 1998). 
Consistent with the state as a whole. of which Cumberland County comprises a large part. the service sector dominates employment. accounting for about one third of the total jobs (Table 3.6). Likewise, retail trade makes up about a quarter of jobs. Wholesale trade. with $8 \%$ of employment reflects Portland's role as a regional distribution center. Cumberland County relies less on manufacturing employment than any other county at $12 \%$ of the total employment. Of this 12 percent only $15 \%$ comes from the lumber and wood or paper and allied products categories. although in absolute numbers these categories employ more workers in these categories than in many of the counties. particularly in the south. These figures are based on an estimate for paper and allied products (Appendix A).

\section{Franklin County}

Franklin County, located in the western mountain region. ranks seventh among counties in land area with 1.744 square miles. The 1995 population of roughly 30.000 has increased 6.99 percent since 1980 and only 1.7 percent since 1990. reflecting a decreasing rate of population growth in the county over the last five years. It is the tenth fastest growing county in the state. Franklin County ranks twelfth in population density with 12 persons per square mile, far below the 37 person per square mile average for the state. Franklin County contains fewer residents over the retirement age of 65 . with only $13 \%$ of the population in this category. Its residents have achieved slightly above the state average education levels, with $79.7 \%$ of the age 25 and older population having earned a high school diploma or equivalent and 17.7 percent of the same population having earned a college degree. The 1994 civilian labor force stood at 14,360 workers. 
The county's labor force experienced the seventh highest unemployment rate in the state at $7.9 \%$, and a per capita income of $\$ 15.713$ in 1993. reflecting Franklin as one of the poorer counties (CBER 1998 and Table 3.6).

The service sector accounts for almost $29 \%$ of Oxford County's total 1995 employment of 10.939 . less than the $37 \%$ from the manufacturing sector. This makes the county one of the more dependent on the manufacturing sector. Of the manufacturing employment. the lumber and wood products contributes $18 \%$ or 735 workers and paper and allied products between 1.000 and 2.499 workers giving a combined contribution that indicates the significance of the forest products industry in this county with a large manufacturing sector. Retail trade employs roughly one quarter of the county's workers (Appendix A).

\section{Hancock County}

Hancock County. located in the northeast coastal region. ranks eighth among counties in land area with 1.657 square miles. The 1995 population of roughly fifty thousand persons has increased 15.2 percent since 1980 and $4.7 \%$ percent since 1990 . a higher growth rate than most counties ranking fifth for the period of 1980-1995. Hancock County ranks tenth in population density with 30 persons per square mile. below the 37 person per square mile average for the state. Hancock County contains slightly higher residents over the retirement age of 65 than the other counties. Its residents have achieved high education level, ranking second with $83.3 \%$ of the age 25 and older population having earned a high school diploma or equivalent and fourth with 21.4 percent of the same population having earned a college degree. The 1994 civilian labor 
force stood at 26.261 workers. The county's labor force experienced the eighth highest unemployment rate in the state at $7.8 \%$ and a per capita income of $\$ 19.239$ in 1993 (CBER 1998 and Table 3.6).

The service sector accounts for almost $34 \%$ of Hancock county's total 1995 employment of 14.338 followed by retail trade at $25 \%$ and manufacturing at $19 \%$. Of the manufacturing employment the lumber and wood products contributes $5.6 \%$ or 149 workers, and paper and allied products between 1.000 and $2 \%$ giving il significant combined contributions even at the low end of the range. indicating the significance of the forest products industry in this county. These figures are based on estimate for paper and allied products. Construction. at about $9 \%$ of employment contributes the highest percentage of any county for this sector and finance, insurance and real estate makes up almost five percent each (Appendix A).

\section{Kennebec County}

Kennebec County. located in the south central region. ranks tenth among counties in land area with 951 square miles. The 1995 population of roughly 117.000 persons has increased 6.1 percent since 1980 but less than one percent since 1990. making it one of the slowest growing counties in the state. Kennebec County ranks fifth in population density with 123 persons per square mile, reflecting the presence of the city of Augusta. Kennebec County contains an average percentage of residents over the retirement age of 65. at $14 \%$. Its residents have achieved an education level consistent with the state as a whole, with $78.9 \%$ of the age 25 and older population having earned a high school diploma or equivalent and 18.1 percent of the same population having earned a college 
degree. The 1994 civilian labor force stood at 57.306 workers, one of the larger county labor forces in the state. The county's labor force experienced an unemployment rate in the state of $7.2 \%$ and a per capita income of $\$ 19.114$ in 1993 (Table 3.6). Median household income stood at $\$ 32.776$ in 1993 (CBER 1998).

The service sector accounts for almost 39\% of Kennebec county's total 1995 employment of 40.229 followed by retail trade which accounts for another approximately one quarter. Manufacturing made up only $16 \%$ of the county's 1995 employment or 6.366 workers. Of this figure. the lumber and wood products and paper and allied products together account for about $22 \%$ of the manufacturing jobs, indicating a higher degree of dependence on these specific industries than most other counties. particularly those in the southern part of the state. None of the sectors make up more than $5 c_{c}$ of employment (Appendix A).

\section{Knox County}

Knox County, located about halfway up the state's Atlantic coastline. ranks fifteenth among counties in land area with 361 square miles. The 1995 population of roughly 37.000 persons has increased 11.9 percent since 1980 but only 2.8 percent since 1990. placing it in the middle for growth of the sixteen in the state when calculated from the year 1980. Knox County ranks sixth in population density with 104 persons per square mile, still well above the 37 person per square mile average for the state. This is one of the smallest counties by land area with no large cities. Knox County contains more residents over the retirement age of 65 than any other at $17 \%$ with the exception of Lincoln, and Piscataquis counties, which also have a $17 \% 65+$ population. Its residents 
have achieved an average education level. with $80.8 \%$ of the age 25 and older population having earned a high school diploma or equivalent and 19.8 percent of the same population having earned a college degree. The 1994 civilian labor force stood at 18.805 workers, in line with the high retirement age population. The county's labor force enjoyed the third lowest unemployment rate in the state at $5.6 \%$ and a high per capita income of S19.421 in 1993 (Table 3.6). Median household income stood at S28.387 in 1993 (CBER 1998).

The service sector accounts for $37 \%$ of Knox county's total employment followed by retail trade which accounts for roughly a quarter (Appendix A). Similar to the proportion for the whole state. manufacturing makes up about one fifth of the county's employment. Within this sector. the major group lumber and wood products comprise only $2.42 \%$ and the paper and allied products sub-category had no employees. These figures are based on estimate for lumber and wood products. The only other sector making up more than $5 \%$ was construction with $5.67 \%$ (Appendix A).

\section{Lincoln County}

Lincoln County. located about a third of the way up the Atlantic coast. ranks fourteenth among counties in land area with 469 square miles. The 1995 population of roughly 31.000 has increased 18.0 percent since 1980 and 3.1 percent since 1990. making it the third fastest growing county in the state. Lincoln County ranks seventh in population density with 67 persons per square mile. Lincoln County contains a high percentage of residents over the retirement age of 65 . ranking at the top with $17 \%$. Its residents have achieved an education level close to the state average. with $81.4 \%$ of the 
age 25 and older population having earned a high school diploma or equivalent and 22.2 percent having earned a college degree, somewhat above the state average. The 1994 civilian labor force at 15.530 workers. was one of the smallest county workforces in the state. The county's labor force enjoyed the fourth lowest unemployment rate in the state at $6.0 \%$ and a relatively higher per capita income of $\$ 20.483$ in 1993 (Table 3.6).

The service sector accounts for $32 \%$ of Lincoln county's total employment of 6.886 followed by retail trade which accounts for another approximately one third. Manufacturing made up only $11 \%$ of the county's 1995 employment of 788 workers and of this figure. only $3.17 \%$ or 25 jobs can be attributed to lumber and wood products. none to paper and allied products. The only other sector making up more than $5 \%$ is construction at $6.56 \%$ (Appendix A).

\section{Oxford County}

Oxford County, located along the state's western border with New Hampshire. ranks sixth among counties in land area with 2.175 square miles. The 1995 population of roughly 53.000 persons has increased 8.23 percent since 1980 but only 1.6 percent since 1990. Placing it in the middle of the pack in the state. Oxford County ranks eleventh in population density with 25 persons per square mile. below the 37 person per square mile average for the state and contains more residents over the retirement age of 65 than the state average with $16 \%$. Its residents have achieved low education level relative to the rest of the state, with $76.9 \%$ of the age 25 and older population having earned a high school diploma or equivalent and 12.7 percent having earned a college degree. The 1994 civilian labor force stood at 24,482 workers. relatively small among its 
peers. The county's labor force experienced the fifth highest unemployment rate in the state at $9.6 \%$ and a per capita income of $\$ 15.830$ in 1993 . well below the state average of 18,780 (CBER 1998) (Table 3.6).

The service sector accounts for almost 35\% of Oxford County's total 1995 employment of 14.383 followed by manufacturing at $30 \%$. making the county one of the most dependent on the manufacturing sector. Of the manufacturing employment the lumber and wood products contributes $42 \%$ (1.829 workers) and paper and allied products between 1,000 and 2.499. Specific data for these figures were withheld to avoid disclosing data for an individual company. Even at the low end of the range these data indicate the significance of the forest products industry in this county. which is especially significant if one looks at the importance of the manufacturing sector in the county's economy. Retail trade only employs about a fifth of the workers (Appendix A).

\section{Penobscot County}

Penobscot County ranks fourth among counties in land area with 3.556 square miles. The 1995 population of roughly $1+5.905$ persons has increased 6.1 percent since 1980 but decreased one half a percent since 1990. reflecting a negative rate of population growth in the county over the last five years. Penobscot County ranks ninth in population density with 41 persons per square mile, close to the 37 person per square mile average for the state. This county encompasses a relatively large land area and contains the city of Bangor. Penobscot County contains fewer residents over the retirement age of 65 than the state, ranking near the bottom $\left(13^{\text {th }}\right)$. Its residents have achieved average education levels, with $79.1 \%$ of the age 25 and older population having earned a high school 
diploma or equivalent and 17.7 percent having earned a college degree. The 1994 civilian labor force stood at 71.707 workers. The county's labor force experienced an unemployment rate of $7.7 \%$ and a per capita income of $\$ 17.711$ in 1993 . below the state average of 18,780 (CBER 1998 and Table 3.6).

The service sector accounts for almost 34\% of Kennebec county's total 1995 employment of 52.579 followed by retail trade which accounts for another approximately one quarter. Manufacturing made up only about one fifth of the county's 1995 employment of 10.284. Of this figure the lumber and wood products and puper and allied products together account for a significant $45 \%$ of the manufacturing jobs. indicating a higher degree of dependence on these specific industries than most other counties. particularly those in the southern part of the state. The Jumber and wood products major group contributes $15 \%$ to manufacturing employment, and paper and allied products contributes $30 \%$. Wholesale trade makes up $6.5 \%$, and transportation and public utilities $6.8 \%$ indicating a more diverse economy than most of the other counties which where a larger percentage of all employment is in service, retail and manufacturing. None of the remaining sectors make up more than $5 \%$ of employment (Appendix A).

\section{Piscataquis County}

Piscataquis County, located in the north central region. ranks second among counties in land area with 4.377 square miles. The 1995 population of roughly 18,000 persons has increased only 4.6 percent since 1980 and decreased almost one percent since 1990 making this one of the slowest growing counties in the state. Piscataquis County, with no urban areas, ranks last in population density with four persons per square mile. 
far below the 37 person per square mile average for the state. Piscataquis County contains more residents over the retirement age of 65 than most counties at $17 \mathrm{c}$. Its residents have achieved relatively low education levels, with $75.4 \%$ of the age 25 and older population having earned a high school diploma or equivalent and 12.3 percent of the same population having earned a college degree. The 1994 civilian labor force stood at 8.338 workers. The county's labor force experienced the fourth highest unemployment rate in the state at $9.6 \%$ and the lowest per capita income of $\$ 14.560$ in 1993 (Table 3.6). Median household income stood at \$25.762 in 1993 (CBER 1998).

The service sector accounts for about a quarter of Piscataquis County's total 1995 employment of only 4,641 workers, and unlike most other counties, less than the $39^{c} \mathrm{c}$ from manufacturing. This makes the county the most dependent on the manufacturing sector. Of the manufacturing employment. the lumber and wood products contributes $47 \%$ or 842 workers and paper and allied products a $0 \%$, indicating the significance of the forest products industry in this county which is especially significant if you look th the importance of the manufacturing sector in the county's economy. Retail trade employs roughly one quarter of the workers (Appendix A).

\section{Sagadahoc County}

Sagadahoc County. located on the southern coast, ranks last among counties in land area with 252 square miles. The 1995 population of roughly thirty thousand persons has increased 15.2 percent since 1980 but only 1.2 percent since 1990 . Growth slowed in the county over the last five years. although it is the fourth fastest growing county in the state. Sagadahoc County ranks fourth in population density with 135 persons per square 
mile. significantly above the 37 person per square mile average. This is expected from a small county in the more populous southern coastal region. Sagadahoc County contains the smallest percentage of residents over the retirement age of 65 . with $11 \%$. Its residents have achieved a high education level relative to the rest of the state. with $81.1 \%$ of the age 25 and older population having earned a high school diploma or equivalent and 21.6 percent having earned a college degree. The 1994 civilian labor force stood at 15.555 workers, a small number consistent with the size and population of the county. The county's labor force enjoyed the lowest unemployment rate in the state at $4.9 \%$ and as relatively high per capita income of $\$ 19.156$ in 1993 (Table 3.6).

It is very difficult to assess Sagadahoc County's economy using County Business Patterns due to the size of its workforce. There were only 14.469 workers in all the sectors combined in 1995 (Table 3.6). The US Bureau of Census uses code letters to signify a range of employees when there are relatively few worker in a sector. major group or more detailed minor group. This is done so that individual business establishments can't be identified. thus protecting the privacy of businesses and workers. The manufacturing sector and all of its major groups have letter designations for Sagadahoc County, obscuring the true employment figures for the manufacturing sector. although the letter code indicates 5.000 to 9.999 workers in the manufacturing sector which would represent 35 to 69 percent of manufacturing employment. Even at $35 \%$ manufacturing employment accounts for a higher proportion of employment than most counties (Appendix A). 


\section{Somerset County}

Somerset County. located in the north central region, ranks third among counties in land area with 4.095 square miles. The 1995 population of roughly 50.000 persons has increased 12.3 percent since 1980 and 3.1 percent since 1990 . reflecting a decreasing rate of population growth in the county over the last five years. Somerset County ranks fourteenth in population density with 13 persons per square mile. far below the 37 person per square mile average for the state. Somerset County contains fewer residents over the retirement age of 65 than most of the other counties. Its residents have achieved low education levels, with $71.9^{\circ} \mathrm{r}$ of the age 25 and older population having earned a high school diploma or equivalent and 10.5 percent of the same population having earned a college degree. The $199+$ civilian labor force stood at 24.428 workers. The county's labor force experienced the third highest unemployment rate in the state at $10.8 \%$ and one of the lower per capita income of $\$ 15.192$ in 1993 (CBER 1998) (Table 3.6).

The service sector accounts for about a quarter of Somerset County's total 1995 employment of 14.414 workers. less than the $32 \%$ from manufacturing. making the county one of the most dependent on the manufacturing sector. Of the manufacturing employment the lumber and wood products contributes $34 \%(1.603$ workers $)$ and paper and allied products a $37 \%$ indicating the significance of the forest products industry in this county which is especially significant if one looks at the importance of the manufacturing sector in the county's economy. These figures are based on estimate for paper and allied products. Retail trade employs roughly one fifth of the total workers.

The only remaining sector with more than $5 \%$ is wholesale trade with $5.2 \%$ (Appendix A). 


\section{Waldo County}

Waldo County, located in the south central region. ranks twelfth among counties in land area with 751 square miles. The 1995 population of roughly 35.000 persons has increased 13.9 percent since 1980 and 7.5 percent since 1990. reflecting the highest rate of population growth in the state over the last five years. Waldo County ranks eighth in population density with 48 persons per square mile. slightly above the 37 person per square mile average for the state. Waldo County contains fewer residents over the retirement age of 65 than the state average of 14 , at $13 \%$. Its residents have achieved below average education levels. with $77.4 \%$ of the age 25 and older population having earned a high school diploma or equivalent and 16.8 percent of the same population having earned a college degree. The 1994 civilian labor force stood at 16.625 workers, one of the smaller county workforces. The county's labor force experienced a relatively high unemployment rate of $8.8 \%$ and a per capita income of $\$ 14.963$ in 1993 , well below the state average of $\$ 18,780$ (CBER 1998 and Table 3.6).

The service sector accounts for almost 33\% of Waldo county's total 1995 employment of 5.783 followed by retain trade and manufacturing which each contribute about a third of the county's employment. Of this figure the lumber and wood products and paper and allied products together account for about $16 \%$ of the manufacturing jobs. nearly all in lumber and wood products, although some of these figures are estimated so the actual number may vary (see explanation in Appendix A). Transportation and public utilities is the only other sector to employ more than $5 \%$ of the workforce (Appendix A). 


\section{Washington County}

Washington County, the easternmost of counties. ranks fifth among counties in land area with 2.736 square miles. The 1995 population of roughly 36.000 persons has increased 3.3 percent since 1980 and 2.35 percent since 1990, reflecting relatively static population dynamics. Washington County ranks thirteenth in population density with 13 persons per square mile, far above the 37 person per square mile average for the state. Washington County contains a relatively high percentage over the retirement age of 65 at $16^{c} \mathrm{c}$. Its residents have achieved relatively high education levels, with $73.2 \%$ of the age 25 and older population having earned a high school diploma or equivalent and 12.7 percent of the same population having earned a college degree. The 1994 civilian labor force stood at 15.498 workers. The county's labor force experienced the highest unemployment rate in the state at $12.5 \%$ and the second lowest per capita income of S14.617 in 1993 (CBER 1998 and Table 3.6).

The service sector accounts for about a third of Washington County's total 1995 employment of only 7.863 workers. exceeded by $29 \%$ from retail trade and about equal to $25 \%$ manufacturing. Of the manufacturing employment the lumber and wood products contributes $23 \%$ (459 workers) and paper and allied products a $38 \%$ indicating the significance of the forest products industry in this county. these figures are based on estimate for paper and allied products (Appendix A).

\section{York County}

York County, the southernmost of Maine counties, ranks ninth among counties in land area with 1.015 square miles. The 1995 population of roughly one hundred and 
seventy one thousand persons has increased 18.3 percent since 1980 and 3.7 percent since 1990. The growth of the last five years is one of the highest in the state although still reflective of an overall decreasing rate of population growth in the state. York County ranks third in population density with 168 persons per square mile. York County contains a percentage of residents over the retirement age of 65 below the state average of 14.4 , at $13 \%$. Its residents have achieved a relatively high education level, with $79.5 \%$ of the age 25 and older population having earned a high school diploma or equivalent and 19 percent having earned a college degree. The 1994 civilian labor force stood at 84.814 workers, the second most of any county. The county's labor force experienced an unemployment rate of $6.2 \%$. Its residents enjoyed a relatively high per capita income of \$19.344 in 1993 (CBER 1998 and Table 3.6).

York County's service sector employs slightly less than one third of jobs followed closely by retail trade at $28 \%$, a reflection of the numerous tourist related restaurants and miscellaneous retail establishments of this recreational area (Appendix A). Manufacturing makes up about one quarter of the county employment. Less than $5 \%$, or 353 workers total. of manufacturing employment comes from the lumber and wood or paper and allied products categories, indicating that these activities do not contribute a significant portion of the economy. This is an estimate for paper and allied products. No other major sector category makes up more than $5 \%$ of the employment (Appendix A). 
Table 3.6

\section{Maine Counties : General Profile}

\begin{tabular}{|c|c|c|c|c|c|c|c|c|c|}
\hline County & Maine & Androscoggin & Aroostook & Cumberland & Franklin & Hancock & Kennebec & Knox & Lincoln \\
\hline Land Area (sq mi) & $33,265.00$ & 497 & 6,819 & 915 & 1,744 & 1,657 & 951 & 361 & 469 \\
\hline Land Area Aank & na & 13 & 1 & 11 & 7 & 8 & 10 & 15 & 14 \\
\hline 1995 population & $1,241,382$ & 103,751 & 78,633 & 248,526 & 29,511 & 49,272 & 117,000 & 37,372 & 31,334 \\
\hline 1990 population & $1,227,928$ & 104,259 & 86,936 & 243,135 & 29,008 & 46,948 & 115,904 & 36,310 & 30,357 \\
\hline 1980 population & $1,125,043$ & 99,509 & 91,344 & 215,789 & 27,447 & 41,781 & 109,889 & 32,941 & 25,691 \\
\hline$\%$ change $80-90$ & 8.4 & 4.6 & -5.07 & 11.2 & 5.38 & 11.01 & 5.2 & 9.3 & 15.4 \\
\hline$\%$ change $80-95$ & 9.4 & 4.1 & -16.16 & 13.2 & 6.99 & 15.20 & 6.1 & 11.9 & 18.0 \\
\hline$\%$ change $90-95$ & 1.1 & -0.5 & -10.56 & 2.2 & 1.70 & 4.72 & 0.9 & 2.8 & 3.1 \\
\hline Rank '80-'95 growth & na & 14 & 16 & 6 & 10 & 5 & 12 & 8 & 3 \\
\hline 1995 Pop. Density & 37 & 209 & 12 & 272 & 17 & 30 & 123 & 104 & 67 \\
\hline 1995 Pop. Density Rank & na & 2 & 15 & 1 & 12 & 10 & 5 & 6 & 7 \\
\hline Percent 65+ & - & 14 & 15 & 14 & 13 & 15 & 14 & 17 & 17 \\
\hline Percent hs grad 25+ 1990 & 78.8 & 71.8 & 70.9 & 85.0 & 79.7 & 83.3 & 78.9 & 80.8 & 81.4 \\
\hline Percent hs grad 25+ rank & & 15 & 16 & 1 & 6 & 2 & 8 & 5 & 3 \\
\hline Percent coll grad $25+1990$ & 18.8 & 12.6 & 12.5 & 27.6 & 17.7 & 21.4 & 18.1 & 19.8 & 22.2 \\
\hline Percent coll grad 25+ rank & na & 13 & 14 & 1 & 9 & 4 & 7 & 5 & 2 \\
\hline civ labor force ' 94 & 612.000 & 54,835 & 37,944 & 125,102 & 14,360 & 26,621 & 57,306 & 18,805 & 15,530 \\
\hline civ labor force ' 94 rank & na & 5 & 6 & 1 & 15 & 7 & 4 & 10 & 13 \\
\hline Percent unemployed & - & 7.5 & 11.7 & 5.1 & 7.9 & 7.8 & 7.2 & 5.6 & 6.0 \\
\hline Percent unemployed rank & na & 10 & 2 & 15 & 7 & 8 & 11 & 14 & 13 \\
\hline Per capita income '93 & 18,780 & 18,286 & 15,238 & 23,063 & 15,713 & 19,239 & 19,114 & 19,421 & 20,583 \\
\hline Per capita income '93 rank & na & 8 & 12 & 1 & 11 & 5 & 7 & 3 & 2 \\
\hline Number of farms 1992 & 5,776 & 302 & 884 & 440 & 210 & 291 & 490 & 217 & 202 \\
\hline Percent land in farms & $6\rceil$ & 21 & 8.00 & 10 & 4.00 & 5.00 & $17 \mid$ & 12 & 8 \\
\hline
\end{tabular}


Table 3.6

Maine Counties : General Profile

\begin{tabular}{|c|c|c|c|c|c|c|c|c|}
\hline County & Oxford & Penobscot & Piscataquis & Sagadahoc & Somerset & Waldo & Washington & York \\
\hline Land Area (sq mi) & 2,175 & 3,556 & 4,377 & 252 & 4,095 & 751 & 2,736 & 1,015 \\
\hline Land Area Rank & 6 & 4 & 2 & 16 & 3 & 12 & 5 & 9 \\
\hline 1995 population & 53,440 & 145,905 & 18,486 & 33,959 & 51,346 & 35,707 & 36,156 & 170,984 \\
\hline 1990 population & 52,602 & 146,601 & 18,653 & 33,535 & 49,767 & 33,018 & 35,308 & 164,587 \\
\hline 1980 population & 49,043 & 137,015 & 17,634 & 28,795 & 45,049 & 28,414 & 34,963 & 139,739 \\
\hline$\%$ change $80-90$ & 6.77 & 6.5 & 5.46 & 14.1 & 9.48 & 13.9 & 1.0 & 15.1 \\
\hline$\%$ change $80-95$ & 8.23 & 6.1 & 4.61 & 15.2 & 12.26 & 20.4 & 3.3 & 18.3 \\
\hline$\%$ change $90-95$ & 1.57 & -0.5 & -0.90 & 1.2 & 3.08 & 7.5 & 2.3 & 3.7 \\
\hline Rank ' 80 -'95 growth & 9 & 11 & 13 & 4 & 7 & 1 & 15 & 2 \\
\hline 1995 Pop. Density & 25 & 41 & 4 & 135 & 13 & 48 & 13 & 168 \\
\hline 1995 Pop. Density Rank & 11 & 9 & 16 & 4 & 14 & 8 & 13 & 3 \\
\hline Percent 65+ & 16 & 13 & 17 & 11 & 13 & 13 & 16 & 13 \\
\hline Percent hs grad 25+ & 76.9 & 79.1 & 75.4 & 81.1 & 71.9 & 77.4 & 73.2 & 79.5 \\
\hline Percent hs grad $25+$ rank & 11 & 9 & 12 & 4 & 14 & 10 & 13 & 7 \\
\hline Percent coll grad 25+ & 12.7 & 17.7 & 12.3 & 21.6 & 10.5 & 16.8 & 12.7 & 19.0 \\
\hline Percent coll grad $25+$ rank & 11 & 8 & 15 & 3 & 16 & 10 & 12 & 6 \\
\hline civ labor force ' 94 & 24,482 & 71,707 & 8,388 & 15,555 & 24,428 & 16,625 & 15,498 & 84,814 \\
\hline civ labor force ' 94 rank & 8 & 3 & 16 & 12 & 9 & 11 & 14 & 2 \\
\hline Percent unemployed & 9.6 & 7.7 & 9.6 & 4.9 & 10.8 & 8.8 & 12.5 & 6.2 \\
\hline Percent unemployed rank & 5 & 9 & 4 & 16 & 3 & 6 & 1 & 12 \\
\hline Per capita income ' 93 & 15,830 & 17,711 & 14,560 & 19,156 & 15,192 & 14,963 & 14,617 & 19,344 \\
\hline Per capita income '93 rank & 10 & 9 & 16 & 6 & 13 & 14 & 15 & 4 \\
\hline Number of farms & 346 & 524 & 140 & 120 & 413 & 339 & 372 & 482 \\
\hline Percent land in farms & 5.00 & 5 & 1.00 & 12 & 4.00 & 15 & 6.00 & 10 \\
\hline
\end{tabular}




\section{Findings}

Many sources of data and methodologies are available for economic and demographic characterization of Maine and its sub-regions. In this chapter the county is identified as a useful level of analysis. in part due to the availability of detailed data on employment and payroll. These data are central to the hypothesis that employment in the forest products industry at the county level correlate to the votes in the 1996 and 1997 forestry practices referenda.

An examination of Maine`s geography reveals its varied landscapes. from a rocky coastline to mountainous regions of the Appalachian chain. The most relevant feature for this research is the Northern Forest. which blankets $90 \%$ of the state's land area. primarily in the northern and western regions. Much of this forestland contains commercially valuable species of trees that the forest products industry uses for the production of lumber. paper and related products. Unlike other areas of the country. the vast majority of forestlands are held in private ownership in Maine. In fact. eight large corporations held almost $50 \%$ of all forestlands in 1994.

Maine is one of the stronger states in terms of land use regulation. These regulations are administered almost exclusively at the municipal and state level. A notable feature of the state's land use regulatory structure is that its 416 unincorporated territories are governed by a land use regulatory commission known as "LURC" which reviews and grants permits for certain types of development. The Maine Forest Service is responsible for tree harvesting practices that are regulated by the state. which also grants municipalities the power to regulate timber harvesting practices. Policy-making bodies, 
most notably the Northern Forest Lands Council. have a visible and influential role in the development of land use regulations in the Northern Forest and are part of a larger debate on the fate of the Northern Forest.

In terms of demographics Maine has a slightly older population than the average for the country and its residents are overwhelmingly white and non-hispanic. Roughly half of the state population resides in four southwestern counties and in general the bulk of the population lives in the southern and coastal part of the state. This distribution of the population is important because the outcome of the 1996 and 1997 forestry practices referenda was determined on the basis of a statewide vote count where the more densely populated areas in the southern and coastal areas had far greater representation than voters in the sparsely populated north where the forestry practices regulations would take effect.

The service sector dominates the state economy. employing one out of every three workers in 1995. but compared to the United states as a whole or other New England states. the forest products industry, represented by major groups under the manufacturing sector. is an important component. The forest products industry contributes $6 \%$ to overall state employment and roughly a third of the states manufacturing employment. The forest products industry is by far the most important contributor to the states total value of manufactured products. The important aspect of the state economy in terms of this research is that there is a great deal of variation in the contribution of the forest products industry to the economies of individual counties. The Northern Forest Counties are more dependent on the forest products industry that counties in the rest of the state. 
Profiles of individual counties. which include forest products industry employment. reveal a great deal of range in the figures for demographic and economic variables. The differences among the counties provide important clues to the results of the 1996 and 1997 referenda. This relationship is discussed in Chapter Five. 


\section{Chapter Four}

\section{The 1996 and 1997 Maine Forestry Practices Referenda}

\section{Introduction}

The purpose of this chapter is to outline information relevant to an understanding of the origins of the 1996 and 1997 referenda, the geographic distribution of the votes. and to describe their correlation with demographic and other variables.

The chapter begins with a discussion of the Diamond International land deal. which served as one of the initial catalysts for proposed changes to forestry practices regulation. This chapter continues with a discussion of the origin of the original initiative that would have banned clearcutting in the unincorporated territories. mainly in the Northern Forest. had it been passed by Maine's voters in the 1996 general election. This chapter discusses the origin of the response to the original initiative, the Compact for Maine's Forests. and a third option. "None of the Above". The campaign efforts by opponents and proponents of the three choices in the 1996 election are described, as are the actual voting results and their geographic distribution.

This chapter also makes an attempt to assess the role of the media in influencing the outcome of the 1996 election. Following a similar structure to the 1996 referendum. the runoff election that resulted from the 1996 vote is discussed in terms of campaigning, geographic distribution of the votes, and the role of the media in influencing the voting results. 


\section{The Diamond International Deal}

In 1988 Diamond International Corporation. experiencing pressure to divest some of its timber landholdings in the wake of a hostile takeover, started a complicated chain of events that led to the 790.000 -acre portion of their 970,000 of timberland holdings in the Northern Forest of Maine ultimately being sold to a combination of the State. The Nature Conservancy and several paper companies. This alarmed both environmentalists. who feared that this was the beginning of fundamental land use changes that would be detrimental to Northern Forest ecosystems, and the forest products industry whose leaders feared that large tracts of land would be removed from timber production. making it harder for the industry to cheaply obtain the raw materials needed to make lumber. paper. and related products (NFLC 1994). Another fear of environmentalists was that timber landholders would increase harvests in anticipation of selling land to development speculators. land that many environmentalists and others believed was already being overharvested.

These fears led to the creation of The Northern Forest Lands Study, whose charge was to gather economic. biological and social data on the Northern Forest. and later the Council of Governors and The Northern Forest Lands Council. whose charges from Congress was to make recommendations based on an intensive study of the complex land use issues concerning in this region. Regulations to limit clearcutting had been in place since passage of the Forestry Practices Act in 1989. The Forestry Practices Act placed a limit on the size of clearcuts at 250 acres, required buffers between clearcuts, and required owners to plant trees if the clearcut area did not regenerate naturally. "Since the 
law went into effect, annual clearcutting has averaged about 55.000 acres statewide. That means that 13 percent of all the acres from which trees are taken are clear-cut. The remaining 87 percent of acres are harvested with partial cuts, in which loggers remove some trees and leave others for the future" (Bradbury 1996, 2-3). Many environmentalists, believing that these regulations were not enough to protect Northern Forest ecosystems, advocated tougher regulation. A source well informed about forest products industry, on the other hand. stated it was difficult to get permission to clearcut over 70 acres. much less the 250 acre maximum and that the regulations were already stringent (Whitney 1999).

In the late 1980s sentiment against large clearcuts increased both inside and outside the forest products industry. Foresters and commercial woodland managers within the industry feared a backlash against clearcuts with the potential to turn the public against forest management in general. Ecologists and environmentalists outside the industry feared that increased clearcuts and the monoculture of commercially valuable softwoods that replace them would make the next outbreak of spruce budworm. a destructive insect that kills commercially valuable trees. worse than the disastrous one experienced previously. "Environmentalists were becoming more vocal, and aerial photographs of sprawling clearcuts in Maine started appearing in regional publications" (Dobbs and Ober 1995. 126).

A 1995 Maine Forest Service study concluded that in the period of 1991-1993. that for the most part. industrial landowners were using techniques that encouraged healthy forest growth on the large majority of their land, indicating proper management. However other reports. some also by the Maine Forest Service, painted a conflicting 
picture of the 1995 assessment. One notable environmentalist critic Mitch Lansky, author of Beyond the Beauty Strip stated that many cut areas failed to meet US Forest Service guidelines for healthy forest growth (Bradbury 1996. 3).

\section{The 1996 and 1997 Forestry Practices Referenda}

\section{The "Ban Clearcutting" Initiative}

Frustrated by the hesitancy of the state legislature to address the issue of timber harvesting regulations. and concerned that the forest was being harvested in an unsustainable fashion. the Green party. led by Jonathan Carter began to organize to ban clearcutting entirely in the state's unincorporated territories. The official name of the petition was "An Act to Promote Forest Rehabilitation and Eliminate Clearcutting" hereafter referred to as "Ban Clearcutting". Since the House Joint Standing Committee on Agriculture. Conservation and Forestry recommended that it not pass. and the parallel Senate committee agreed, the bill (petition) was to be put on the ballot without change as required by the Maine Constitution (Maine Secretary of State 1996. Bradbury 1996, and

Maine Constitution). Carter characterized the initiative as pro-jobs because it would encourage the growth of a healthier forest (Bradbury 1996, 3). In the larger context of environmental groups active in Maine, the Green Party was more aggressive in advocating forestry regulation than the more conservative and mainstream groups like the Nature Conservancy and the Sierra Club. The Green Party's 1996 Platform Statement on natural resources, in addition to advocating a ban on clearcutting, proposed that the pulp and paper industry phase out completely the use of chlorine and chlorine-based chemicals 
by the year 2003 and "encourage fully sustainable, labor-intensive and chemical-free forestry practices" (Maine Green Party 1996). These positions were considered "extreme" by the forest products industry and were more radical than many mainstream environmental groups could tolerate.

The Ban Clearcutting initiative specifically said:

- Clearcutting would be prohibited in unorganized territories:

- Landowners would be required to leave more trees standing after a conventional harvest:

- In a 15-year period. no more than one third of the trees could be removed from an acre of timberland:

- The essential mixture of tree species could not be altered:

- Tree limbs must be left near where they are cut:

- The state may grant exceptions after a landowner proves hardship; and

- The effective date would be April 1' 1997.

(Bradbury 1996. 1-2)

According to Article IV, Section 18 of the Maine Constitution. in order for a group to gain access to the statewide ballot. they must first obtain an excess of ten percent of the total vote cast in the preceding gubernatorial election (Maine Constitution). The Green Party, through an extensive signature campaign, was able to assemble more than 54.968 signatures. meeting the requirements to place their Ban Clearcutting initiative on the November 1996 statewide ballot. If passed. the ban on clearcutting would have been 
the first time that any state banned the practice of clearcutting on private land (Bradbury 1996, 1).

\section{A Response to the Initiative}

The Green Party's success prompted immediate concern and debate among property rights organizations, the Governor's office, the forest products industry. mainstream environmental groups, sportsmen. labor unions, and ordinary citizens (Bradbury 1996. 1). The forest products industry in Maine, with 30.000 employees and $\$ 5$ billion in annual generated product value prior to the vote, represented a significant part of the state economy and this was a major concern for all of these groups, directly or indirectly. A more specific concern, that the ban would result in closure of small and independent mills and result in the loss of a large number of jobs. troubled many of these groups. Governor King's position on the issue was that it would stifle the economy and would be extremely expensive to enforce. especially without provision of funding for regulation. King estimated that the referendum's passage would necessitate the hiring of

10 foresters at a cost of $\$ 500.000$ to $\$ 750,000$ per year (Bradbury $1996.1-2$ ). His view of economic hardship was echoed by an article written in a Canadian newspaper that estimated a loss of 15.600 jobs, a $\$ 1.3$ billion drop in economic output. a nearly $20 \%$ reduction in the wood supply, and a steep increase in the price that mills would have to pay for raw materials (Poitras 1996). The State Forest Service estimated that a clearcut ban would decrease the wood harvested in the unorganized territories by 58 percent, at a time when these areas supplied 62 percent of Maine's annual wood harvest (Bradbury 1996, 4). 
Through an extensive negotiation process involving a coalition of Governor King, forest products industry representatives. and mainstream environmental groups. a compromise was made that softened what were perceived as some of the harsher consequences of the ban clearcutting initiative. The major environmental groups involved in creating the Compact were the Nature Conservancy of Maine. Maine Audubon Society and Natural Resources Council of Maine. Some critics. notably the property rights group Stop The Compact. considered the Compact to be a "backroom deal" that was conducted without media or legislature scrutiny (Stop The Compact 1997).

The forest products industry feared that. without any competition. the Ban Clearcutting measure would be successful. Mainstream environmentalists feared a possible backlash against attempts to preserve the forest if the economy suffered as the result of a clearcut ban. These fears gave the negotiations added urgency.

The coalition was under the time constraint of having to work out a forestry practices compromise and get it approved by the legislature as a resolution in time to be included on the November 1996 ballot to compete against the Ban Clearcutting initiative. The resolution, entitled LD 1892: An Act to Implement the Compact for Maine's Forests. was passed by the House and Senate during the Second Special Session of the 117 th Legislature and approved by the Governor in time for inclusion on the ballot (Appendix B). The resolution was to be put on the ballot as "Competing Measure under the Constitution of Maine to Implement the Compact for Maine's Forests" (hereafter called "the Compact") and would. pending voter acceptance, result in enactment of the following provisions: 
- A policy statement regarding forest management and land use:

- Increased restrictions on clearcutting including a 75-acre maximum (with some exemptions and variances allowed) and a permit requirement:

- Enhanced notification requirements for municipalities proposing enactment of or amendments to timber harvesting ordinances and State payments to municipalities for associated costs;

- Establishment of the Sustainable Forest Management Program as a voluntary program within the Department of Conservation to encourage improvement in forest management and to optimize ecological and economic health of the forests:

- Authorization for the Bureau of Parks and Lands to establish between 8.000 and 10.000 acres of ecological forest reserves on public lands;

- Completion by March 1. 1997 of an assessment by the Maine Forest Service of the expected impact of the provisions in this competing measure resolution on timber liquidation;

- Legislation to be submitted by the Governor by April 1. 1997 to further restrict timber liquidation; and

- Development of natural resource education initiatives for the general public and convening of a natural resource education advisory committee to work with the natural resource educator in the Bureau of Forestry (OPLA 1996).

Although the ballot question that would be put to the voters were simple. the legislation behind them was complex and would give the state legislature a large mandate for placing further restrictions on timber harvesting (Whitney 1999). 


\section{A Third Option}

A third option, "none of the above". was put on the ballot in accordance with the Maine Constitution. which states: "The measure thus proposed, unless enacted without change by the legislature at the session at which it is presented shall be submitted to the electors together with any amended form. substitute, or recommendation of the legislature. and in such manner that the people can choose between the competing measures or reject both" (Maine Constitution).

Property rights activists were at least in part represented by the voice of Mary Adams of Common Sense for Maine's Forests and Alliance for America. She voiced the opinion of many property rights groups that the compact was a "land grab" by environmental organizations, in particular because it referred to set asides of "ecological forest reserves", and that small tract owners, those with less than 100,000 acres. would be hurt by the Compact. which was negotiated with the large timber tract holders. A complete ban on clearcutting was not considered an option by property rights activists who tended to support the "none of the above" option (Ellsworth American 1997 and Settler's Advocate 1996). A trade publication Pulp and Paper. stated after the election that the third option "none of the above" had most of its votes delivered by private property rights proponents.

Ron Arnold, vice president of the Center for the Defense of Free Enterprise (CDFE) explained the property rights position in The Center's Issues and Positions on the World Wide Web (Center for the Defense of Free Enterprise 1997). This position is that government land should be put into private hands, and that restrictions on land use result in regulatory takings and should be abolished. 
Brian Bishop. Director of Rhode Island Wise Use. a property rights organization, wrote a piece called A Visit to Maine: Ruminations of an Outsider for Digestion of Insiders which provided another glimpse at the property rights perspective. In it he stated his opinion that the media supporting the clearcut ban deceptively framed the issue as "the interests of the average person against those of big paper companies" but that many people believed it was an attempt to ban on forestry in general. and by extension. their livelihood. He considers the clearcut ban as a strategy to manage the aesthetics of private land for the public.

The results of the November 5. 1996 referendum tabulated by Maine`s Bureau of Corporations. Elections and Commissions in General Election Tabulations for the Election of November 5. 1996. was that the Compact for Maine's Forests received the most votes statewide with $48 \%$ versus $28 \%$ for the clearcut ban and $23 \%$ for "none of the above".

\section{The 1996 Referendum Campaign}

A unique characteristic of this referendum/initiative is that while area that the three forestry practices ballot options would affect lies in the sparsely populated unincorporated territories. mostly within the Northern Forest. the outcome would be decided by the majority of voters residing in the more urbanized south (Bradbury 1996). There were over half a million registered voters before the referendum in November 1996, but only 15 percent of the voting age population lived in the Northern Forest counties of Aroostook, Piscataquis. Somerset and Washington where the regulations would cover the majority of the land area (Bradbury 1996.3). As is common with 
referenda. the initial response to the ban clearcutting initiative, before the other two options became available. was positive. with polls showing that over $70 \%$ of voting age population supported the initiative.

An article in the Portland Press Herald characterized support for the clearcut ban. as of March before the election. as being heavy in the southern and more urban areas. carrying a $71 \%$ approval rating for the state as a whole according to one poll (Bradbury 1996. 4). Voter sentiment changed in the months leading up to the election as the proponents of the three referendum options intensified their media campaigns to sway voter opinion in their favor. As is common in referendum and initiative campaigns. the original instinctive support of the idea to ban clearcutting was replaced by a more negative view of its possible consequences by many voters (Cronin 1989.84).

Some portrayed the media campaign for the Compact for Maine's Forests as a conspiracy by Governor King and multinational forest products companies to keep the industry self-regulated. and characterized the professionals hired by compact supporters as "initiative-crushers" (Huber 1998). Others painted grim pictures of what would happen if clearcutting was banned outright. including the loss of thousands of jobs and an over one billion dollars decrease in the state's economic output (Poitras 1998). This uncertainty may have kept any of the ballot options from gaining a clear majority.

\section{The 1996 Referendum Results}

As mentioned in the previous section. some counties had much greater importance in terms of number of voters (Table 4.1). For example, just the two southernmost counties of York and Cumberland together accounted for more than a third of the 
combined votes for options "Ban Clearcutting" (appearing as item $2 \mathrm{a}$ on the ballot), the Compact for Maine"s Forests (appearing as item 2b on the ballot). and "None of the Above (appearing as item $2 \mathrm{c}$ on the ballot). The most significant blocks of voters in terms of numbers at the municipal level were centered around the Portland (Cumberland County). Lewiston-Auburn (Androscoggin County), Augusta (Kennebec County). and Bangor (Penobscot County) areas. In fact if one considers just these cities and the municipalities immediately adjacent to these cities. they can account for 23 percent. or 138.496 voters of the 596.874 total voters. These figures highlight the importance of urban areas to the outcome of the vote.

\section{Table 4.1: Total Votes on Question 2 Options by County}

\begin{tabular}{|l|r|r|}
\hline & \multicolumn{2}{|c|}{ Question 2a, 2b, 2c } \\
\hline County & Tot '96 Voters & '96 of \% Maine Total \\
\hline Androscoggin & 46,350 & 7.77 \\
\hline Aroostook & 34,002 & 5.70 \\
\hline Cumberland & 127,457 & 21.35 \\
\hline Franklin & 3,870 & 0.65 \\
\hline Hancock & 26,103 & 4.37 \\
\hline Kennebec & 54,859 & 9.19 \\
\hline Knox & 18,464 & 3.09 \\
\hline Lincoln & 17,830 & 2.99 \\
\hline Oxford & 7,299 & 1.22 \\
\hline Penobscot & 69,880 & 11.71 \\
\hline Piscataquis & 8,940 & 1.50 \\
\hline Sagadahoc & 16,580 & 2.78 \\
\hline Somerset & 22,924 & 3.84 \\
\hline Waldo & 17,012 & 2.85 \\
\hline Washington & 14,867 & 2.49 \\
\hline York & 81,040 & 13.58 \\
\hline Total & 596,874 & 100 \\
\hline
\end{tabular}

\section{Geographic Information Systems Data and Methodology}

Geographic Information Systems (GIS) are a tool for collecting, storing, retrieving, transforming, and displaying spatial data for a particular purpose. GIS can be 
used to handle complex spatially referenced data in a way that it can be generalized for analysis (Burrough and McDonnell 1998). Two basic data types are used in GIS: graphic. consisting of points, lines and polygons. and attributes consisting of non-graphical data. These two fundamental types of data are linked by geographic location identifiers (Kaiser and Godschalk 1995). Economic, demographic and voting tabulation data provide the material to create attribute tables which can then be linked to spatially oriented graphic elements such as county and municipal boundaries and presented visually (Kaiser and Godschalk 1995). There are many sources and types of GIS datasets available for this research project. which has economic social. political. and land use elements. The sources include:

- Statewide political boundaries compiled from 1:64.500 scale United States Geological Survey (USGS) quadrangle maps including standard town names. identifiers for county, and identifiers for whether the town is organized or unorganized. (Maine Office of GIS 1998):

- Voting data. which can be merged with the previously described data coverages. (Maine Bureau of Corporations, Elections and Commissions 1996 and 1997):

- Economic data which can be merged with the previously described data coverages (U.S. Bureau of Census 1995); and

- Demographic data which can be merged with the previously described data coverages (U.S. Bureau of Census 1996). 
These data can be analyzed with GIS to identify the spatial correlation between economic and demographic variables and how votes were cast on specific referenda.

The following section will discuss the voting results and their spatial variation. displayed using GIS. from the 1996 and 1997 referenda.

\section{Distribution of the Votes}

Statewide. the vote on referendum question 2 came out as $30 \%$ for Ban Clearcutting (question 2a), $47 \%$ for the Compact (question 2b). and $23 \%$ for None of the Above (question 2c). However there was a considerable degree of variation in the geographic distribution of support for the three measures.

By county. support for the clearcut ban. which did not receive the majority of the vote in any county. ranged from 19.1 to 35.6 percent with the greatest support in the more urban coastal counties of Cumberland. York. Sagadahoc. and Hancock and the least support in the Northern Forest Counties of Aroostook. Piscataquis. Franklin, and Oxford. At the county level, the Compact drew the largest percentage of the vote in all counties except Piscataquis, where the None of the Above won with the most votes (Table 4.2 and Figure 4.1). 


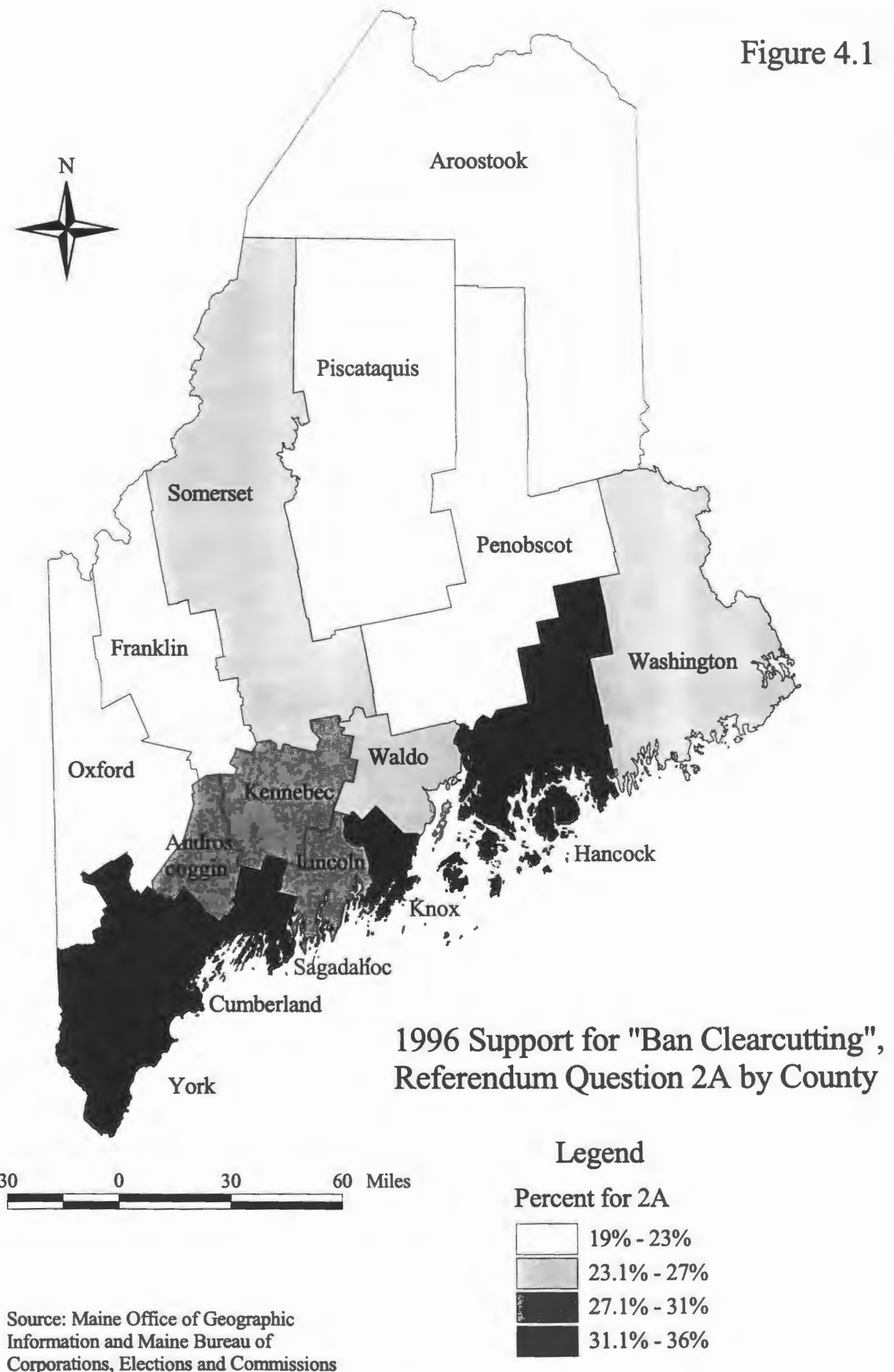


These results bring up the question of how the counties most supportive of a ban on clearcutting differ from those that are least supportive of a ban on clearcutting in terms of the characteristics described in the county profiles in Chapter Three. The four counties most supportive of the clearcut ban without exeption have (1) a higher percentage of college educated residents: (2) lower unemployment rates: (3) a higher per capita income; (4) a higher population density: (5) a lower percentage of land under LURC jurisdiction: and (6) and are less dependent on the forest products industry for employment than the four counties least supportive of a ban on clearcutting.

Table 4.2: Counties Showing Greatest and Least Support for Ban Clearcutting, Question 2a

\begin{tabular}{|l|c|}
\hline County & Percent voting for option 2a \\
\hline Cumberland & 35.6 \\
\hline York & 35.5 \\
\hline Sagadahoc & 34.4 \\
\hline Hancock & 31.6 \\
\hline Aroostook & 19.1 \\
\hline Piscataquis & 20.0 \\
\hline Franklin & 20.3 \\
\hline Oxford & 20.4 \\
\hline
\end{tabular}

Interestingly. at the municipal level, there were only 15 towns in the state where question 2a won, four in Washington County, three in Hancock County, two in York and Waldo Counties, and one in Cumberland, Lincoln, Oxford and Somerset Counties. Eight counties contained no towns where 2 a won. In the town of Denmark, located in Oxford 
County which showed the least support for the Clearcutting Ban. the Clearcut Ban won. although narrowly, over the Compact (Figure 4.2).

By county, support for the Compact ranged from 39.6 to 53.8 percent with the greatest support in the Northern Forest counties of Aroostook. Franklin. and Oxford. and Androscoggin County, and the least support in the three easternmost coastal counties of Waldo. Hancock. and Washington, and the Northern Forest county of Piscataquis (Table 4.3 and Figure 4.2). In terms of how the counties most supportive of the Compact differ from those that are least supportive the Compact by the characteristics (variables) described in the county profiles in Chapter Three, the characteristics are much different than for question $2 \mathrm{a}$. Unlike question $2 \mathrm{a}$, the most and least supportive counties do not exhibit strong differences in level of education, both high school and college. or for any of the other variables.

Table 4.3: Counties Showing Greatest and Least Support for the Compact, Question 2b

\begin{tabular}{|l|c|}
\hline County & Percent voting for option $\mathbf{2 b}$ \\
\hline Aroostook & 53.8 \\
\hline Franklin & 53.0 \\
\hline Oxford & 51.6 \\
\hline Androscoggin & 49.1 \\
\hline Piscataquis & 39.6 \\
\hline Waldo & 41.7 \\
\hline Hancock & 42.5 \\
\hline Washington & 42.6 \\
\hline
\end{tabular}




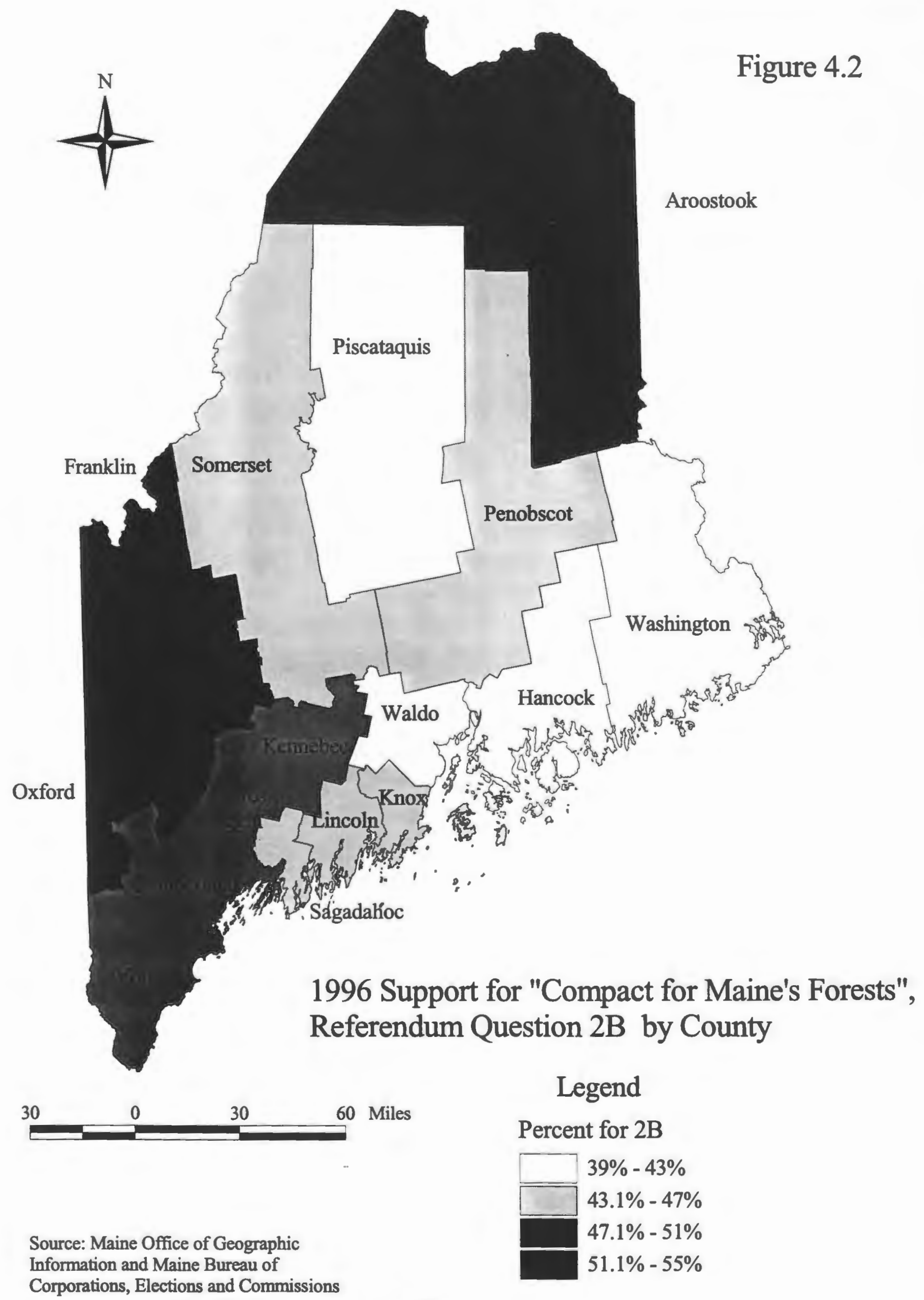


Although the percentage of support was greatest in the Northern Forest Counties. a look at the votes at the municipal level reveals that in the southwestern counties of York. Cumberland. Androscoggin. Sagadahoc and Lincoln the Compact won in almost every town. As can be seen in Table 4.1. the towns in these counties contained nearly half of the total votes in the state. so although the margins were smaller. the absolute numbers of Compact supporters were larger.

By county. support for "None of the Above" ranged from 16.9 to 40.4 percent with the greatest support in the center of the state in the counties of Piscatatquis. Waldo. Washington. Penobscot and Oxford and the least support in the three easternmost coastal counties of Waldo. Hancock, and Washington. and the Northern Forest county of Piscataquis (Table 4.4 and Figure 4.3).

Table 4.4: Counties Showing Greatest and Least Support for None of the Above, Question 2c

\begin{tabular}{|l|c|}
\hline County & Percent voting for option 2c \\
\hline Piscataquis & 40.4 \\
\hline Waldo & 32.0 \\
\hline Washington & 31.2 \\
\hline Penobscot & 30.8 \\
\hline York & 16.9 \\
\hline Cumberland & 17.1 \\
\hline Sagadahoc & 18.1 \\
\hline Kennebec & 21.2 \\
\hline
\end{tabular}




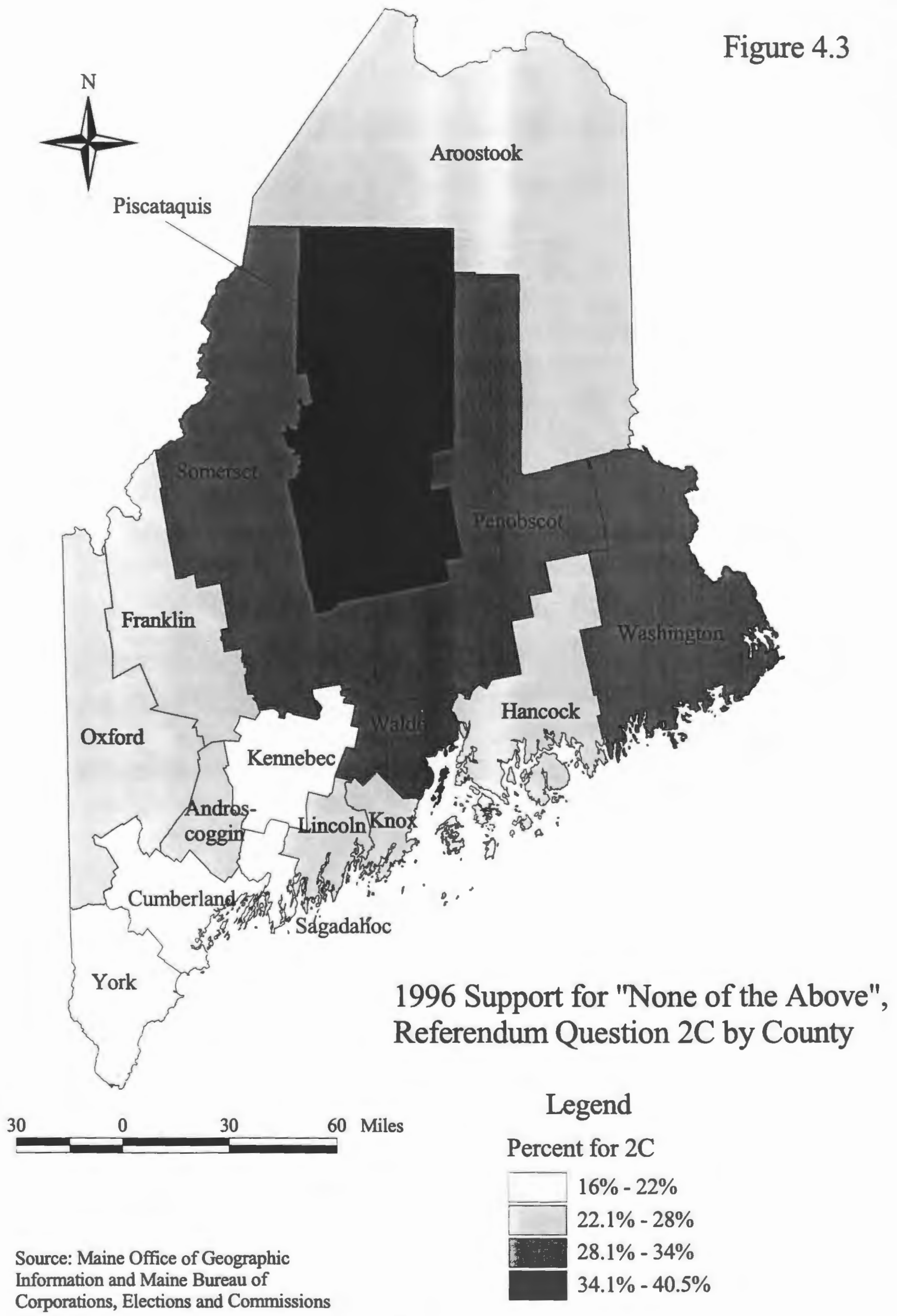


Like the counties that were most supportive of the clearcut ban. the counties most supportive of the none of the above option differ from those that are least supportive in terms of the characteristics described in the county profiles in Chapter Three. only in a different way. The four counties most supportive of the none of the above option without exeption have (1) a lower percentage of high school and college educated residents: (2) higher unemployment rates: (3) a lower per capita income: (4) a lower population density: and (5) and higher dependence on the forest products industry for employment than the four counties least supportive of a ban on clearcutting. These characteristics are directly opposite to the characteristics of the counties most supportive of the clearcut ban. There did not appear to be any clear differences between the most and least supportive counties in area under LURC jurisdiction. Piscataquis County stands out as the only county where none of the above won and where the Compact did not receive the most votes of the three options. This brings up the question of how Piscataquis County is different from the other counties that supported the none of the above option but where it didn't gain the majority of the vote. The notable characteristics of this county are that it contains no urban areas. has the lowest population density and the lowest per capita income of all the counties. This suggests that there is something about the land use ethic and lifestyle of voters in rural areas that is associated with opposition to government regulation of land use practices.

By municipality, the areas where None of the Above won tended to show up in clusters with a large and almost continuous block centered in Penobscot County and extending into Waldo. Kennebec and Piscataquis Counties. Other smaller blocks appear 
in the rest of the counties away from those in the southwest where the Compact won in nearly all of the towns.

These results show that counties exhibiting the most support for the clearcutting ban have nearly opposite characteristics from the counties most supportive of the none of the above option and that most and least supportive counties for the Compact do not exhibit distinct differences. These results and their significance will be discussed in more detail in Chapter Five.

\section{The Runoff Election}

According to Maine's Constitution. when there are competing referenda and none receives a majority of the votes. the one receiving the most votes is put on the ballot in the next statewide election, provided that it received more than one third of the vote (Maine Constitution). The votes on the Compact satisfied these requirements and it was slated to be put on the ballot in November 1997 with the option of "yes" or "no" for the Compact. The Compact for Maine's Forests was listed as Question 1: Carry-over measure and was worded: "Do you want the Compact for Maine's Forests to become law to promote sustainable forest management practices throughout the state?" (Maine 1997 and Grenzke. et. al. 1998).

This election. in addition to the carry-over measure, contained measures for three bond issues. a constitutional amendment and a referendum question dealing with funding for improvements to the Maine Turnpike. Unlike the 1996 referenda vote, which was part of a general election, the 1997 referendum vote was part of a special election.

Specifically the carry-over measure contained the following provisions: 
- The Commissioner of Conservation must adopt statewide rules overseeing timber harvesting, subject to subsequent review by the Legislature.

- Requires the establishment of a voluntary audit program.

- Landowners must get a permit from the Commissioner of Conservation before doing any clearcutting. The landowner would have to justify reasons for clearcutting.

- Permitted clearcuts subject to size. proximity to other clearcuts and total area under one ownership restrictions.

- The Commissioner must to adopt rules regarding forest regeneration after a timber harvest.

- Municipalities may adopt timber harvesting ordinances that are more restrictive than the State's rules.

- It would make certain state-owned land off limits to timber harvesting.

- Placed harvest restrictions on land held for less than ten years.

The voters were given the option on the ballot of accepting of rejecting the Compact for Maine's Forests. The compact was rejected by fifty three percent of Maine's voters.

In addition to Governor King and mainstream environmental groups. supporters of the Compact in 1997 included the AFL-CIO. the Pulp and Paper Workers Resource Council, the Sportsman's Alliance for Maine and the Maine Forest Products Council. Opposition to the Compact from property rights groups such as Mary Adams`Common Sense for Maine' Forests was strong. As in 1996. property rights groups were upset that small timberlot owners were not represented in the creation of the Compact and felt that 
the creation of "ecological preserves" on state land represented a "land grab". Opposition to the Compact from clearcutting proponent Jonathan Carter of the Green Party and Forest Ecology Network, and other critics centered around the voluntary nature of many of the Compact provisions and some technical aspects of the language that could result in incentives to make larger clearcuts, which were at the time averaging 34 acres. well below the 75 that the compact would allow (Ellsworth American 1997). The Compact was defeated by a margin of 53 percent against and 47 percent for (State of Maine. 1997).

\section{The Role of the Media in the 1997 Election}

According to some polls. many voters were confused by the Compact even though it had been available for examination for more than a year. This confusion. which some sources describe as media-induced may have been crucial for the surprise defeat of the Compact (Grenzke, Swope and Carter 1998. 33). Media influence on the 1997 election will be discussed in greater detail in Chapter Five.

\section{Voting Results}

The 1997 election turnout was higher than expected. although nearly all the counties experienced a dramatic dropoff in the number of voters from the 1996 to the 1997 elections, in the range of around 40 percent. This dropoff phenomenon can be explained by the fact that the 1996 election was in a presidential year when more people typically vote than in off-year elections as in 1997. The three notable exceptions to a dropoff in turnout were Franklin and Oxford Counties where the turnout more than doubled (126 and 116 percent increase respectively) and Piscataquis County where the 
number of voters increased by 8 percent. These counties with the greatest increase in voters were also. interestingly, ones where support for the Compact declined the most with decreases in support of $12.1 \%$ for Piscataquis. $8.6 \%$ for Franklin and $6.5 \%$ for Oxford County. The percentage voting yes for the Compact ranged from $27.5 \% \mathrm{c}$ in Piscataquis to $54.7 \%$ in York County. The Compact won in the two most populous counties. Cumberland and York and in Sagadahoc County. As can be seen on a map. these are the three southernmost of Maine's Counties (Figure 4.4). In 1996 Aroostook was the most supportive of counties for the Compact and was the only one of the top four supporters of the Compact in 1996 to be in the top four in support again in 1997. although the Compact lost the vote by a slim 2.2 percent. Of the four counties least supportive of the Compact in 1996. three of them. Piscataquis. Waldo. and Washington. were the least supportive again in 1997.

Table 4.5: Counties Showing Greatest and Least Support for the Compact, Question 1

\begin{tabular}{|l|c|}
\hline County & Percent voting for question 1 \\
\hline York & 54.7 \\
\hline Cumberland & 53.5 \\
\hline Sagadahoc & 50.5 \\
\hline Aroostook & 47.8 \\
\hline Piscataquis & 27.5 \\
\hline Somerset & 35.5 \\
\hline Waldo & 36.4 \\
\hline Washington & 37.7 \\
\hline
\end{tabular}



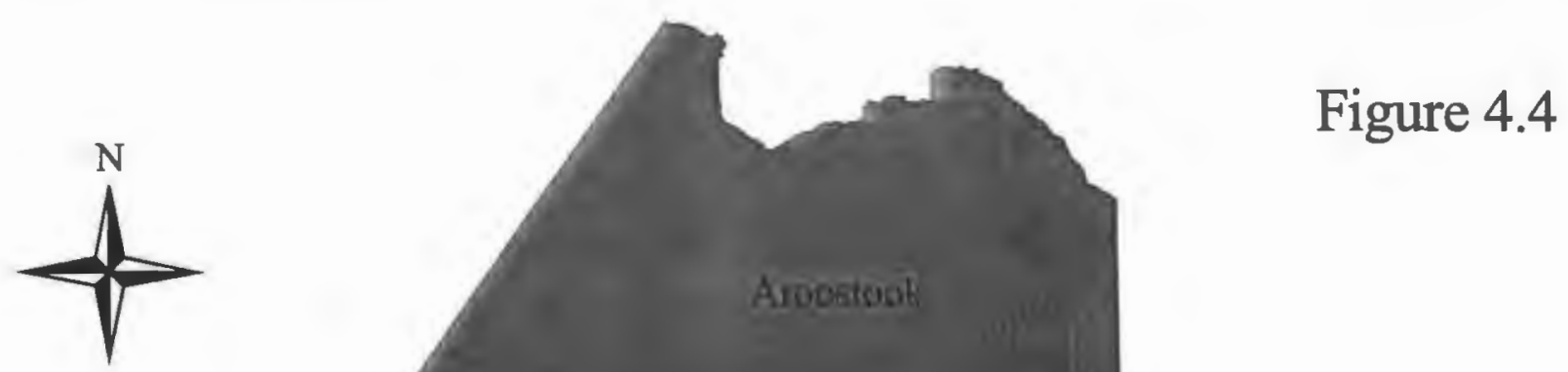

\section{Arnosiont}

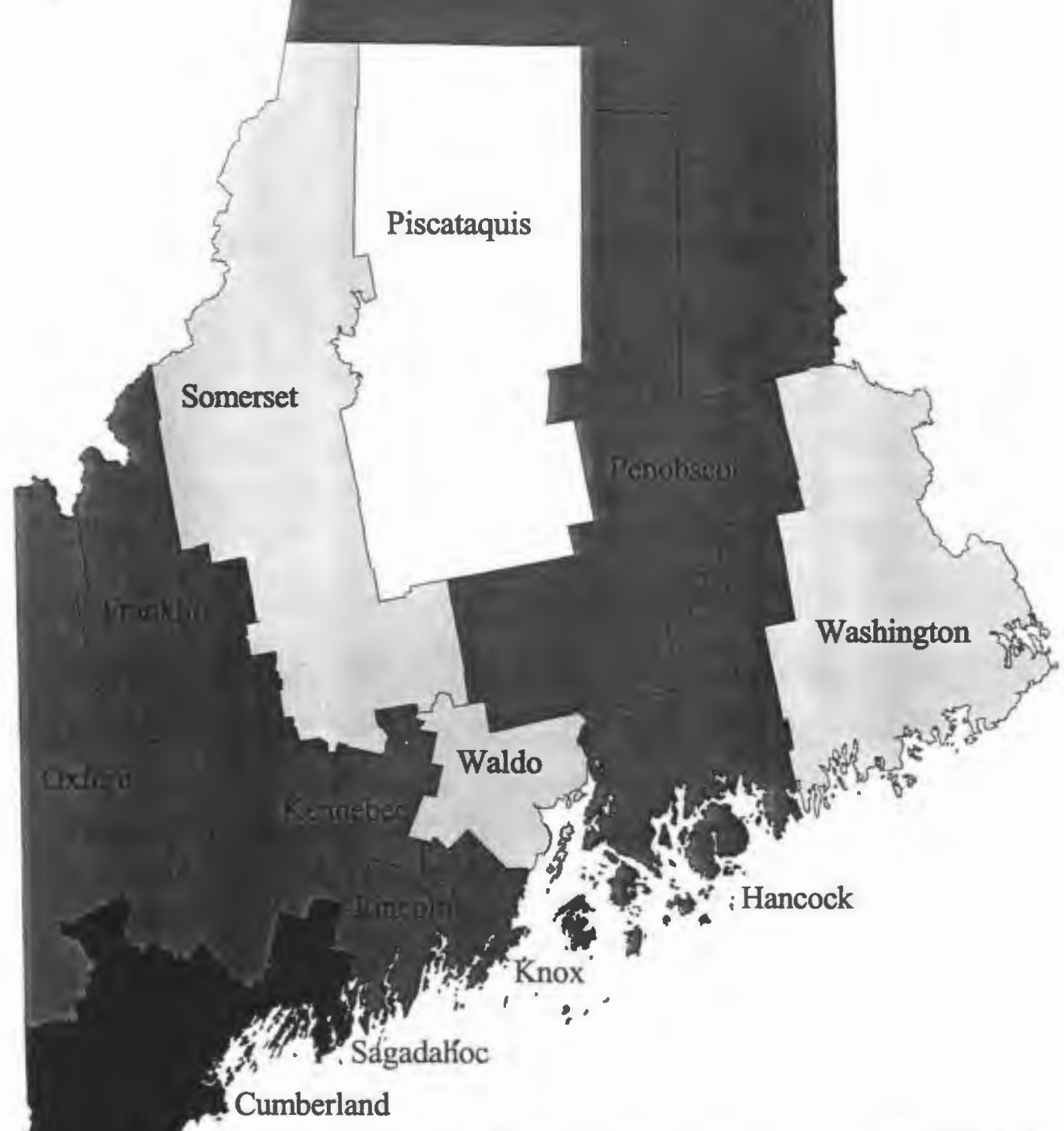

1997 Support for "Compact for Maine's Forests",

York Referendum Question 1 by County

Legend

Percent Voting Yes

for Question 1

$27 \%-34 \%$
$34.1 \%-41 \%$
$41.1 \%-48 \%$
$48.1 \%-55 \%$

Source: Maine Office of Geographic Information and Maine Bureau of

Corporations, Elections and Commissions 
The four counties most supportive of the Compact in the 1997 election show very similar characteristics to the four counties that were most supportive of the clearcutting ban in 1996, in fact three of the four that were most supportive of the ban in 1996 were most supportive for the Compact in 1997. The characteristics are: (1) higher percentage of high school and college educated residents. with the exeption of Aroostook County; (2) lower unemployment and higher per capita income. with the exeption of Aroostook County: (3) higher population density, with the exeption of Aroostook County: and (4) lower dependence on the forest products industry for employment. with the exeption of Aroostook County.

The areas of highest support for the Compact at the municipal level appears to be very "patchy" although concentrated in the southwestern and extreme northern portions of the state. The least support tended to be on or near the borders of unincorporated territories where, as mentioned earlier. people vote in the nearest town in the appropriate house or senate district.

\section{After Defeat}

Governor King characterized the opposition to the compact as "the most bizarre coalition in the history of Maine politics. "a blend of "far-end" enviro groups and conservative property rights activists..." (Greenwire 1998).

Both Jonathan Carter of the Green Party and Mary Adams of Common Sense for Maine's Forests (a property rights advocacy group) felt that the defeat of the Compact was a victory for them. Carter, thinking that it sent a clear message to the seven largest paper 
companies that clearcutting will not be tolerated and Adams thinking that it showed that the people in Maine didn't want more regulation (Ellsworth American 1997).

\section{Findings}

Initiatives and referenda have long been used for political change and many types of issues have been put to the public for a vote. There exists a long-standing debate over the value of using initiatives and referenda to elicit political change over the traditional lawmaking process. Proponents of initiatives and referenda maintain that they make for a more accountable government and encourage citizen involvement in important issues. Opponents maintain that many issues are too complex for the average voter to understand and that most voters will selfishly vote with their pocketbooks i.e. what is best for them economically and not society as a whole. Another criticism of initiatives and referenda is that they are too easily influenced by campaign spending. often in the form of biased media campaigns, and that these media campaigns often confuse voters rather than making them more knowledgeable of the issues.

The 1996 and 1997 referenda trace their history back to the Diamond International land deal in 1988 when 790,000 acres of Maine's Northern Forest were transferred to a combination of state agencies. environmental groups and other paper companies. This worried both environmentalists fearing large-scale forest liquidation. and the forest products industry which feared that commercial forestland would increasingly be off limits for commercial harvesting. At around the same time as this major land transaction. public sentiment against clearcutting was on the rise. This set the stage for Jonathan Carter, leader of Maine`s Green Party at the time, to capitalize on his frustration with the 
prospects for stricter clearcutting regulation and begin gathering signatures for an initiative to ban clearcutting. Maine`s governor. the forest products industry, and mainstream environmental groups developed an alternative to the clearcut ban called The Compact for Maine`s Forests. A third option. one that rejected both the ban and the Compact. was required by the state constitution to be placed alongside the other two options on the ballot.

Most of Maine's voters reside in its more urban southern counties while only $15 \%$ of the state's voters reside in the Northern Forest Counties of Aroostook. Piscataquis. Somerset and Washington. There was strong initial support for the clearcut ban followed by an intense media campaign by all sides and a drop in support for the clearcut ban as Compact forces and property rights groups used media spots to capitalized on fears that a ban would cause widespread economic damage.

The results of the 1996 and 1997 election are well suited for analysis using Geographic Information Systems (GIS) methodology. which can reveal otherwise invisible spatial patterns in the votes.

Spatial analysis of the votes reveals that the clearcutting ban had the most support in the more urbanized southern counties although it did not receive the majority of the vote in any county. The Compact attracted the majority of the vote in all of the counties except Piscataquis, where the none of the above option won.

Descriptive analysis of the correlation between support and opposition for the three ballot options and the characteristics of counties produced the following results:

- Counties most supportive of the clearcut ban were more educated, experienced lower unemployment, had a higher per capita income. a higher population density, a lower 
area of land under LURC jurisdiction and were less dependent on the forest products industry for employment than those counties least supportive of the ban.

- Counties most supportive of the Compact were not clearly different from those least supportive in terms of education. unemployment per capita income. population density, area of land under LURC jurisdiction or dependence on the forest products industry for employment.

- Counties most supportive of the none of the above option were less educated. experienced higher unemployment, had a lower per capita income, a lower population density, and were more dependent on the forest products industry for employment than those counties least supportive of the none of the above option.

- Counties most supportive of the clearcutting ban exhibited characteristics that were directly opposite to those most supportive of the none of the above option.

With no one option receiving more than $50 \%$ of the vote statewide. a runoff election was required to be held the next year as required by Maine; Constitution. As in the 1996 election, the various sides used media extensively to try and influence the outcome of the referendum. in some cases confusing voters about the economic and environmental impact of the Compact. As is often the case in off-year elections, voter turnout dropped off substantially. in the range of $40 \%$ statewide.

Descriptive analysis of the correlation between support and opposition for the Compact and the characteristics of counties produced the following results: 
- The four counties most supportive of the Compact in the 1997 were more educated, with the exeption of Aroostook County. experienced lower unemployment and higher per capita income, again with the exeption of Aroostook County had higher population density. with the exeption of Aroostook County, and were less dependent on the forest products industry for employment, with the exeption of Aroostook County.

The four counties most supportive of the Compact in the 1997 election show very similar characteristics to the four counties that were most supportive of the clearcutting ban in 1996. in fact three of the four that were most supportive of the ban in 1996 were most supportive for the Compact in 1997. 


\section{Chapter 5}

\section{Analysis. Discussion and Conclusion}

\section{Introduction}

The purpose of this chapter is to integrate the findings from a descriptive analysis of the results of the 1996 and 1997 referenda from the previous chapter with quantitative analysis to further assess the validity of the research hypotheses outlined in Chapter One. This chapter also contains a discussion of the analysis results and their relevance to land use decision makers in Maine and elsewhere in the United States.

\section{Methods for Using Inferential Statistics for Hypothesis Testing}

Chi square tests are a popular way to test hypotheses, especially in social research. because of their versatility. Chi-squares are especially useful where the variables of

interest have more than two categories and where there are more than wo samples. Chisquares enable the researcher to measure the degree to which the relationship between two variables is random (Healy 1996. 250).

The testing of research questions can be accomplished using a null hypothesis, based on the assumption of data randomness. Expected frequencies are developed based on the randomness assumption and can be compared to the observation frequencies. In this study an attempt was made to determine quantitatively whether there is a significant correlation between support for the Compact in the 1996 and 1997 elections. 
Another useful statistical method for the testing of research questions, stepwise multiple regression. was employed to quantitatively analyze the separate effects of each independent variable on the dependent variable and to determine the combined effect of all of the independent variables on the dependent variable (Healy 1996, 438). The research hypotheses are outlined in the introduction and below in Table 5.1. 
Table 5.1: Variables Used for Statistical Analysis

\begin{tabular}{|c|c|c|c|c|c|c|c|c|c|}
\hline $\begin{array}{l}\text { Dependent } \\
\text { Variable }\end{array}$ & $\begin{array}{l}\text { Independent } \\
\text { Variable 1 }\end{array}$ & $\begin{array}{l}\text { Independent } \\
\text { Variable } 2\end{array}$ & $\begin{array}{l}\text { Independent } \\
\text { Variable } 3\end{array}$ & $\begin{array}{l}\text { Independent } \\
\text { Variable } 4\end{array}$ & $\begin{array}{l}\text { Independent } \\
\text { Variable } 5\end{array}$ & $\begin{array}{l}\text { Independent } \\
\text { Variable } 6\end{array}$ & $\begin{array}{l}\text { Independent } \\
\text { Variable } 7\end{array}$ & Level of Analysis & $\begin{array}{l}\text { Statistical } \\
\text { Analysis }\end{array}$ \\
\hline $\begin{array}{l}\text { Vote for } \\
\text { Compace } \\
1996\end{array}$ & $\begin{array}{l}\text { Vote for } \\
\text { Compace } \\
1996\end{array}$ & & & & & & & $\begin{array}{l}\text { County and } \\
\text { Municipality }\end{array}$ & Chi squalle \\
\hline $\begin{array}{l}\text { Percent } \\
\text { Vote for } \\
\text { Clearcuttin } \\
\text { g Ban }\end{array}$ & $\begin{array}{l}\% 25+ \\
\text { graduated HS }\end{array}$ & $\begin{array}{l}\% 25+ \\
\text { graduated } \\
\text { College }\end{array}$ & $\begin{array}{l}\text { \% Land area } \\
\text { Under LURC } \\
\text { Jurisdiction }\end{array}$ & $\begin{array}{l}\text { Per Capita } \\
\text { Ineome }\end{array}$ & $\begin{array}{l}\text { Population } \\
\text { Density }\end{array}$ & $\begin{array}{l}\text { Percent } \\
\text { Unemployment }\end{array}$ & $\begin{array}{l}\text { \% Forest } \\
\text { Products } \\
\text { Industry } \\
\text { Employment }\end{array}$ & County' & $\begin{array}{l}\text { Multiple } \\
\text { Regression }\end{array}$ \\
\hline $\begin{array}{l}\text { Pereent } \\
\text { Vote for } \\
\text { Compact }\end{array}$ & $\begin{array}{l}\% 25+ \\
\text { graduated HS }\end{array}$ & $\begin{array}{l}\% 25+ \\
\text { graduated } \\
\text { College }\end{array}$ & $\begin{array}{l}\text { \% Land area } \\
\text { Under L.URC } \\
\text { Jurisdiction }\end{array}$ & $\begin{array}{l}\text { Per Capita } \\
\text { Income }\end{array}$ & $\begin{array}{l}\text { Population } \\
\text { Density }\end{array}$ & $\begin{array}{l}\text { Pereent } \\
\text { Unemployment }\end{array}$ & $\begin{array}{l}\text { \% Forest } \\
\text { Products } \\
\text { Industry } \\
\text { Employment }\end{array}$ & County & $\begin{array}{l}\text { Multiple } \\
\text { Regression }\end{array}$ \\
\hline $\begin{array}{l}\text { Percent } \\
\text { Vote for } \\
\text { None of the } \\
\text { Above }\end{array}$ & $\begin{array}{l}\% 25+ \\
\text { graduated HS }\end{array}$ & $\begin{array}{l}\% 25+ \\
\text { graduated } \\
\text { College }\end{array}$ & $\begin{array}{l}\text { Land area } \\
\text { Under LURC } \\
\text { Jurisdiction }\end{array}$ & $\begin{array}{l}\text { Per Capita } \\
\text { Income }\end{array}$ & $\begin{array}{l}\text { Population } \\
\text { Density }\end{array}$ & $\begin{array}{l}\text { Percent } \\
\text { Unemployment }\end{array}$ & $\begin{array}{l}\text { \% Forest } \\
\text { Products } \\
\text { Industry } \\
\text { Employment }\end{array}$ & County & $\begin{array}{l}\text { Multiple } \\
\text { Regression }\end{array}$ \\
\hline
\end{tabular}




\section{Research Hypotheses}

As mentioned in Chapter One, the purpose of this study is to examine social. economic, and other variables as possible independent correlates to the 1996 and 1997 Maine forestry practices referendum votes. The variables used in this examination and described in more detail in Chapter One, are listed in Table 5.1.

\section{Correlation of Variables}

\section{Statistical correlation between the 1996 and 1997 referendum votes}

Chi square analysis was performed as shown in Table 5.2 to determine if a statistically significant relationship exists between majority support for the Compact in the 1996 three-way vote and support for the Compact in the 1997 Compact runoff

election. As mentioned previously, this research hypothesized that counties that voted for the Compact in 1996 would more likely to vote for it again in 1997. In order to make the comparison between the 1996 vote, in which there were three choices (Ban Clearcutting. the Compact. and None of the Above), and the 1997 vote where there were two choices (yes or no for the Compact), the research combined Ban Clearcutting and None of the Above into the "No" vote category for the 1996 vote. 
Table 5.2: Referendum Vote Analysis by County: Vote on Compact 1996 vs. Vote on Compact 1997

\begin{tabular}{|c|c|c|c|}
\hline \multirow[b]{2}{*}{1996 Vote on Compact } & \multicolumn{3}{|c|}{1997 Vote on Compact } \\
\hline & Yes & $\mathrm{No}$ & Total \\
\hline Yes & 3 & 12 & 15 \\
\hline *No & 0 & 1 & 1 \\
\hline Total & 3 & 13 & 16 \\
\hline \multicolumn{4}{|c|}{$*$ combination of votes for question $2 \mathrm{a}$ and $2 \mathrm{c}$} \\
\hline Chi Square (obtained) $=$ & \multicolumn{2}{|c|}{0.12} & \\
\hline Degrees of Freedom $=$ & \multicolumn{2}{|c|}{1} & \\
\hline Alpha $=$ & \multicolumn{2}{|c|}{0.05} & \\
\hline Chi Square $($ critical $)=$ & \multicolumn{2}{|c|}{0.24} & \\
\hline
\end{tabular}

\section{Findings}

The analysis of the relationship of the votes for the Compact at the county level in the two years indicates that the relationship between the variables was not statistically different from what would be expected from a random distribution. However. data at the county level may not be a sufficiently meaningful level of aggregation for looking at the relationship between the votes in these two years. particularly when using chi squares for analysis. This is because with only 16 counties, most of the possible combinations contain less than the desired minimum of five observations. While this deficiency was corrected for statistically, it is desirable to have a greater degree of certainty that there was no relationship between the votes in the two years.

In order to obtain a better analysis of the relationship between 1996 and 1997 voter support for the Compact, this research analyzed the votes by the 506 municipalities 
for which voting data was available for both years as shown in Table 5.3. with the same aggregation as used for the county votes (majority for "Ban Clearcutting" plus "None of the Above" = No).

Table 5.3: Referendum Vote Analysis by Municipality: Vote on Compact 1996 vs. Vote on Compact 1997

\begin{tabular}{|c|c|c|c|}
\hline \multirow[b]{2}{*}{1996 Vote on Compact } & \multicolumn{3}{|c|}{1997 Vote on Compact } \\
\hline & Yes & $\mathrm{No}$ & \multirow{2}{*}{$\begin{array}{l}\text { Total } \\
351\end{array}$} \\
\hline Yes & 113 & 238 & \\
\hline$*$ No & 3 & 152 & 155 \\
\hline Total & 116 & 390 & 506 \\
\hline \multicolumn{4}{|c|}{ * combination of votes for question $2 \mathrm{a}$ and $2 \mathrm{c}$} \\
\hline Chi Square (obtained) $=$ & \multicolumn{2}{|c|}{55.71} & \\
\hline Degrees of Freedom $=$ & \multicolumn{2}{|c|}{1} & \\
\hline Alpha $=$ & \multicolumn{2}{|c|}{0.05} & \\
\hline Chi Square $($ critical $)=$ & \multicolumn{2}{|c|}{0.332} & \\
\hline
\end{tabular}

This analysis reveals that. unlike the county analysis, the relationship between Compact vote in 1997 and the Compact vote in 1996 at the municipal level is statistically significant from what might be expected from a random distribution. Municipalities that roted for the Compact in 1996 were significantly more likely to vote for it again in 1997 (113 municipalities observed v. 80.5 expected). These municipalities that voted yes both times comprise the core of support for the Compact. Conversely, those municipalities that voted against the Compact both years comprise the core of opposition. Municipalities that voted for in '96 and against in '97 indicate that the Compact lost ground and municipalities 
that voted against in '96 and for in '97 indicate areas where the Compact gained ground. There were only three municipalities that met the latter criterion.

\section{Spatial Analysis}

When the votes for 1996 and 1997 are combined. a feature of the voting map that sticks out immediately is the concentration of core support for the compact along the densely populated southern coast running continuously for nearly 100 miles from Maine's border with New Hampshire in Kittery (York County) to Bristol in Lincoln County. The areas of core support that are not along the coast appear in many cases to be in close proximity to large towns and cities (Figure 5.1). This observation will be discussed in the next section. This concentrated area of support is the part of the state that is furthest away from the large mass of unincorporated territories in the north under LURC jurisdiction that the forestry practices regulations would affect. The southern coastal counties also enjoy more diversified economies and less dependence on the forest products industry. as discussed in Chapter Three. With the exception of a few towns along Penobscot Bay, the rest of the coastal municipalities either voted for in 1996, then against the Compact in 1997 or were against it both times. The municipalities in this more northern portion of the coast lie in counties with lower density of populations and having less diversified economies (See Chapter Three). There are also conspicuous areas of support for the Compact in the Northeasternmost part of the state in Aroostook County north and south of Caribou. The area of support along the coast is significant because a large part of the state's voters, who were instrumental to the Compact getting the majority of the vote in the 1996 referendum, reside there. This also shows that although this heavily populated 
area showed majority support for the Compact again in 1997. it was not enough to counterbalance the rest of the state which largely stayed opposed to the Compact or changed from supporting it in 1996 to opposing it in 1997. 

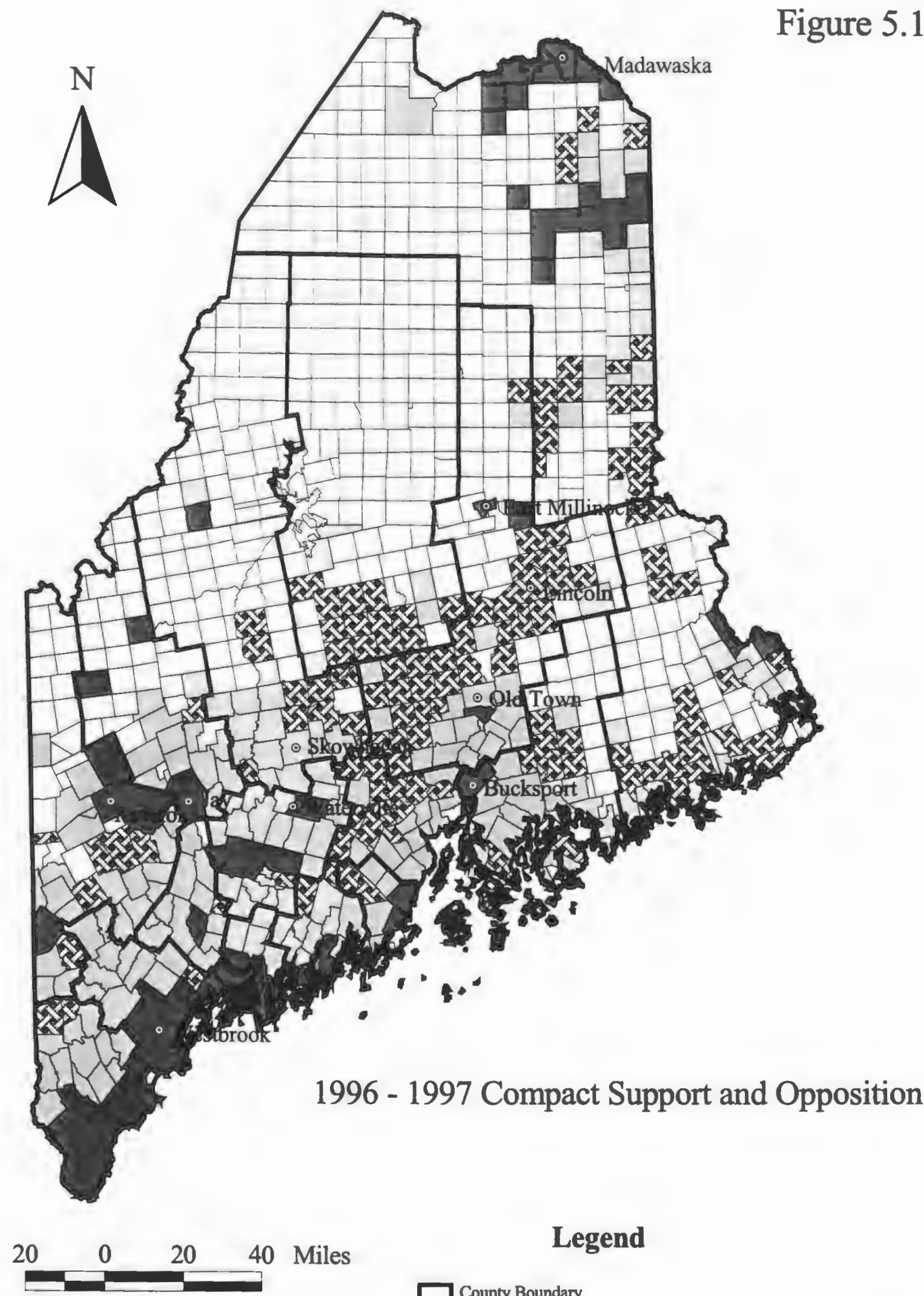

\section{Legend}

County Boundary

Compact Votes

Unincorporated territories (no vote tabulations)

Core Compact Support (majority for compact in both 1996 and 1997)

Core Compact Opposition (majority against Compact in both 1996 and 1997)

Swing Votes (majority for Compact in 1996, majority against in 1997)

Source: Maine Office of Geographic Information 


\section{Municipal Referendum Votes and Large Paper Manufacturing Facilities}

The observation of a concentrated area of core support at the municipal level for the Compact in the densely populated southern counties is generally consistent with the county level analysis in the previous chapter. Counties most supportive of the Compact in 1997 were more densely populated than those least supportive of the Compact. However. some less densely populated counties contain concentrated areas of Compact support at the municipal level. In some cases such Bangor in Penobscot County and Augusta in Kennebec County these concentrated areas surround a city and represent pockets of population density that is more prevalent and visible along the southern coast. Other concentrated areas of Compact support in Franklin. Oxford and Aroostook Counties, for example, are not associated with large cities. The role of large individual forest products manufacturing facilities and their location was examined in an attempt to explain this observation.

To get a more detailed look at the influence of forest products industry employment on the votes, this research examined the ten largest paper manufacturing facilities in Maine and the municipalities in which they are located. The rational behind examining these municipalities is that wood products manufacturing facilities are likely to be their largest employer. As such, these facilities are likely to have a significant impact on the local economy, both directly through payroll and purchase of supplies and services, and indirectly through secondary spending by businesses and individuals. The voting patterns in these municipalities should represent most clearly the economic influence that the presence of the forest products industry has on voter preferences. 
Of the largest six municipalities in terms of employment in single paper products making facilities. all of them were areas of core Compact support. In fact. of the ten largest. seven are in municipalities that roted for the Compact both times.

Many of these paper facility municipalities stand out on the map because they are surrounded by municipalities where the majority voted against the Compact in the 1997 vote. Good examples of this are Waterville in Kennebec County, Bucksport in Hancock County and Jay in Franklin County which are all surrounded by municipalities that roted for the Compact in 1996 and against it in 1997. Although no statistical analysis was done to determine if this relationship is significant. it seems to indicate that municipalities with concentrated forest products industry employment tended to show strong support for the Compact. 
Table 5.4 Large Paper Manufacturing Facilities and 1996/1997 Referendum Votes

\begin{tabular}{|c|c|c|c|c|c|}
\hline Company & Employees & Primary Products & Municipality & County & Vote \\
\hline $\begin{array}{l}\text { Bowater/Great } \\
\text { Northern Paper } \\
\text { Inc. }\end{array}$ & 1.700 & paper products & Millinocket & Penobscot & $\begin{array}{l}\text { core } \\
\text { Compact } \\
\text { support }\end{array}$ \\
\hline $\begin{array}{l}\text { Boise Cascade } \\
\text { Paper Division }\end{array}$ & 1.450 & paper and pulp & Rumford & Oxford & $\begin{array}{l}\text { core } \\
\text { Compact } \\
\text { support }\end{array}$ \\
\hline $\begin{array}{l}\text { International } \\
\text { Paper Co. }\end{array}$ & 1.400 & $\begin{array}{l}\text { paper and paper } \\
\text { products }\end{array}$ & Jay & Franklin & $\begin{array}{l}\text { core } \\
\text { Compact } \\
\text { support }\end{array}$ \\
\hline SD Warren Co. & 1.300 & $\begin{array}{l}\text { fine printing \& } \\
\text { specialty papers }\end{array}$ & Westbrook & Cumberland & $\begin{array}{l}\text { core } \\
\text { Compact } \\
\text { support }\end{array}$ \\
\hline $\begin{array}{l}\text { Champion } \\
\text { International } \\
\text { Corp. } \\
\end{array}$ & 1.250 & $\begin{array}{l}\text { lightweight coated } \\
\text { printing paper }\end{array}$ & Bucksport & Hancock & $\begin{array}{l}\text { core } \\
\text { Compace } \\
\text { supnort }\end{array}$ \\
\hline $\begin{array}{l}\text { Frasier Paper } \\
\text { Linited }\end{array}$ & 1.169 & $\begin{array}{l}\text { specialty paper } \\
\text { products }\end{array}$ & Madawaska & Aroostook & $\begin{array}{l}\text { core } \\
\text { Compact } \\
\text { support }\end{array}$ \\
\hline SD Warren Co. & 1.050 & $\begin{array}{l}\text { lightweight coated } \\
\text { paper }\end{array}$ & Skowhegan & Somerset & $\begin{array}{l}\text { swing vote } \\
\text { (yes-nor) }\end{array}$ \\
\hline The Chinet Co. & 650 & formed fiber products & Waterville & Kennebec & $\begin{array}{l}\text { core } \\
\text { Compact } \\
\text { support }\end{array}$ \\
\hline $\begin{array}{l}\text { James River } \\
\text { Corp. }\end{array}$ & 650 & hardwood kraft pulp & Old Town & Penobscot & $\begin{array}{l}\text { swing vote } \\
\text { (yes-nos) }\end{array}$ \\
\hline $\begin{array}{l}\text { Lincoln Pulp \& } \\
\text { Paper Co. }\end{array}$ & 525 & pulp and paper & Lincoln & Penobscot & $\begin{array}{l}\text { core } \\
\text { Compact } \\
\text { opposition }\end{array}$ \\
\hline
\end{tabular}

Source: Maine Business Online and Maine Bureau of Corporations. Elections and Commissions

Another feature that stands out on the voting map is the large block of core opposition to the Compact in the center of the state west of Bangor in Penobscot.

Piscataquis and Waldo Counties, a large part of which abuts areas of LURC jurisdiction (Figure 5.1). It is notable that overall. more than half $(54 \%)$ of the core opposition municipalities were adjacent to LURC territories. As mentioned previously, the people that live in unorganized territories generally vote in the nearest organized municipality in the appropriate U.S. House and Senate districts, something that county level statistical 
analysis of the data overlooks. This is because I did not have the data that would allow me to distinguish native voters from those from unorganized territories in these border municipalities. Similarly. I couldn't distinguish towns that have a mix of resident voters from those from nearby unorganized territories. The 83 core opposition municipalities adjacent to LURC territory represent 45 percent of all municipalities adjacent to LURC territory. The 28 core support municipalities adjacent to LLRC territory represent only 15 percent of municipalities adjacent to LURC territory, and the 75 municipalities that went from majority support for the Compact to voting against it in 1997 represent 40 percent of all municipalities adjacent to LURC territories. The distribution of the core opposition. with its concentration near areas of LURC jurisdiction may be a result of the influence of voters from unincorporated LURC territory voting in nearby municipalities within the same House and Senate districts. This wouldn `t explain. however, the many core opposition municipalities in this continuous block that are not adjacent to LURC territory. Unlike the region of core Compact support along the coast, the large block of core opposition in the center of the state represents only a small portion of the total vote statewide but may represent the area where property rights groups are the strongest or at least where sentiment against government regulation is the strongest.

\section{Statistical Correlation Between Referenda Votes and Social and Demographic Variables}

In order to obtain a more rigorous analysis of the relationship between the independent variables in the research hypotheses and the voting results in the 1996 and 1997 referenda, a quantitative approach was extended to include multiple regression. 


\section{Chi Square Analysis}

The difficulty encountered with the use of chi square analysis is that when crosstabulating votes for 16 counties with an ordinal or interval level ranking of variables. is that resulting combinations often produced cells that had an expected frequency of less than 5. "When sample size is small, one can no longer assume that the sampling distribution of all possible test statistics is accurately described by the chi square distribution. In the case of the chi square test, a small sample is defined as one where a high percentage of cells have expected frequencies of 5 or less.... In the case of $2 \times 2$ tables. the value of $\mathrm{x}^{2}$ (obtained) can be adjusted by applying Yates correlation for continuity..." (Healy 1996. 261). For tables larger than 2x2. which is what is obtained from the above described analysis. there is no formula for correcting the obtained chi square value for possibilities with less than five observations. Categories of variables can be combined to avoid this problem if there is a clear theoretical justification (Healy 1996. 261). I determined that combining the variables in this way would not result in meaningful information to answer the research questions posed.

\section{Multiple Regression Analysis}

In order to address this problem. this study used the data for the dependent and independent variables in their interval form. For example. instead of aggregating unemployment into a two category ranking (i.e.. counties with above mean state percent unemployment and counties with below mean state percent unemployment), this research used the actual value for each county, which makes the data interval level. For the 
referendum votes, this research used actual percentage of the vote for a particular ballot choice. This allows the use of a stepwise multiple regression analysis to determine collectively which independent variables make a significant contribution to the dependent variables (the 1996 and 1997 referendum rotes). It also allows a determination of how much of the variation in the dependent variable can be explained by significant independent contributors.

A multiple regression analysis was done for four dependent variables:

1. Percent vote for 2a: Ban Clearcutting in 1996

2. Percent vote for 2b: Compact for Maine's Forests in 1996

3. Percent vote for 2c: None of the Above in 1996

4. Percent who voted for the Compact in 1997

Each of these four dependent variables underwent a separate stepwise regression with seren independent variables:

1. Percent of age $25+$ graduated from high school

2. Percent of age $25+$ graduated from college

3. Percent of land area under LURC jurisdiction

4. Per capita income

5. Population density

6. Percent unemployment

7. Percent forest products industry employment. 
Table 5.5 Multiple Regression - Clearcut Ban 1996

\begin{tabular}{|c|c|c|c|c|}
\hline \multicolumn{5}{|c|}{$\begin{array}{l}\text { Variable List: Step Wise Regression Model } \\
\text { Dependent Variable: Percent Vote for 2a: Clearcut Ban } 1996\end{array}$} \\
\hline \multicolumn{5}{|c|}{$\begin{array}{l}\text { Independent Variables Included in Step One: Percent College Graduate. Percent High School Graduate. Area in } \\
\text { LURC Jurisdiction. Per Capita Income. Population Density. Percent Unemployment. Percent Forest Products } \\
\text { Industry Employment } \\
\text { Multiple R: } .884 \\
\text { R Square: } .781\end{array}$} \\
\hline \multicolumn{5}{|c|}{ Significant Variables in the Equation } \\
\hline Variable & B & SE B & BETA & SIG \\
\hline $\begin{array}{l}\text { Percent Forest } \\
\text { Products } \\
\text { Industry } \\
\text { Employment }\end{array}$ & -.488 & .069 & -.884 & 0.05 \\
\hline
\end{tabular}

Table 5.6 Multiple Regression - Compact for Maine's Forests 1996

Variable List: Step Wise Regression Model

Dependent Variable: Percent Vote for 2b; Compact for Maine's Forests 1996

Independent Variables Included in Step One: Percent College Graduate. Percent High School Graduate. Area in LURC Jurisdiction. Per Capita Income. Population Density. Percent Unemployment. Percent Forest Products Industry Employment

Multiple R: na

R Square: na

\begin{tabular}{|l|c|c|c|c|}
\hline \multicolumn{5}{|c|}{ Significant Variables in the Equation } \\
Variable & B & SE B & BETA & SIG \\
\hline na & na & na & na & na \\
\hline
\end{tabular}

Table 5.7 Multiple Regression - None of the Above 1996

Variable List: Step Wise Regression Model

Dependent Variable: Pereent Vote for 2L; None of the Above 1996

Independent Variables Included in Step One: Percent College Graduate. Percent High School Graduate. Area in LURC Jurisdiction. Per Capita Income. Population Density. Percent Unemployment. Percent Forest Products Industry Employment

Multiple R: .794

R Square: 631

\section{Significant Variables in the Equation}

\begin{tabular}{|l|c|c|c|c|} 
Variable & B & SE B & BETA & SIG \\
\hline $\begin{array}{l}\text { Population } \\
\text { Density }\end{array}$ & -.060 & .012 & -.794 & 0.05 \\
\hline
\end{tabular}


Table 5.8 Multiple Regression - Compact for Maine's Forest 1997

Variable List: Step Wise Regression Model

Dependent Variable: Percent Vote for Compact for Maine's Forests 1997

Independent Variables Included in Step One: Percent College Graduate. Percent High School Graduate. Area in LURC Jurisdiction. Per Capita Income. Population Density. Percent Unemployment. Percent Forest Products Industry Employment

Multiple R: .709

R Square: .503

Significant Variables in the Equation

\begin{tabular}{|l|c|c|c|c|} 
Variable & B & SE B & BETA & SIG \\
\hline $\begin{array}{l}\text { Percent Forest } \\
\text { Products } \\
\text { Industry } \\
\text { Employment }\end{array}$ & .001 & .0005 & .709 & 0.05 \\
\hline
\end{tabular}

\section{Independent Variables and the 1996 2a (Ban Clearcutting) Vote}

At the $95 \%$ confidence level. all of the independent variables were removed from the regression equation except for forest products industry employment. Results show an inverse relationship between percent voting to ban clearcutting and forest products industry employment. that is counties with a higher level of forest products industry employment had a significantly lower percentage of votes to ban clearcutting. In fact $78.1 \%$ of the variation in the 2 a vote at the county level can be attributed to the level of forest products industry employment (Table 5.5).

As discussed in Chapter Three, due to the policy of the U.S. Census Bureau to give estimates in many cases to protect the privacy of individual employers. many of the aggregated figures for county forest products industry employment contained at least one component figure that was an estimate.

However, in most instances the uncertainty in the estimate does not alter the employment percent significantly. For example, for Cumberland County, the total of the 
three forest products industry employment categories was $1.9 \%$ of total employment using the halfway method of determining a value for an estimated range for category 2600: paper and allied products. Assuming that actual employment was at the very bottom of the range for this category, the result would be total forest products industry employment of 1.3 percent. Assuming that the actual employment was at the very top of the range would result in a total forest products industry employment of $2.4 \%$. not a very large difference from the halfway method. In some of the other counties. such as Hancock, the differences in the upper and lower ends of the estimate range are greater in percentage terms because the forest products industry employment represents a larger proportion of total employment. however when counties are compared to each other the this uncertainty does not affect their relative ranking.

This quantitative analysis supports the descriptive analysis of the 1996 ban clearcutting vote in Chapter Three where counties most supportive of the ban exhibited less dependence on the forest products industry for employment than those counties least supportive of the ban.

\section{Independent Variables and the 1996 2b (Compact) Vote}

At the $95 \%$ confidence level all of the variables were removed from the regression equation. This indicates that there were no significant correlation between any of the independent variables and the Compact vote (Table 5.6). Descriptive analysis in Chapter Three produced a similar result: counties most supportive of the Compact were not clearly different from those least supportive in terms of any of the independent variables. 


\section{Independent Variables and the 1996 2c (None of the Above) Vote}

At the $95 \%$ confidence level all of the variables were removed from the regression equation except for population density. Results show an inverse relationship between percent voting for the None of the Above option and population density. Counties with a lower population density had were significantly more likely to vote for the None of the Above option. In fact $63.1 \%$ of the variation in the 2 a vote at the county level can be attributed to population density (Table 5.7). This quantitative analysis supports the descriptive analysis of the 1996 none of the above vote in Chapter Three where counties most supportive of this option exhibited lower population than those counties least supportive of the ban.

\section{Independent Variables and the 1997 Compact Vote (Yes/No)}

At the $95 \%$ confidence level all of the variables were removed from the regression equation except for per capita income. This analysis showed that $50.3 \%$ of the variation in the Compact vote can be attributed to per capita income. Counties with higher per capita income were significantly more likely to vote for the Compact than those with lower per capita income (Table 5.8).

This quantitative analysis supports the descriptive analysis of the 1997 Compact vote in Chapter Three where counties most supportive of the Compact (with one exception) exhibited higher per capita income than those counties least supportive of the Compact. 


\section{Agreement Between Results of Descriptive and Quantitative Analysis}

The question that arises when comparing the results of descriptive and quantitative analysis is why didn't all of the variables that appeared to be correlated to roting results in the descriptive analysis appear as statistically significant in the quantitative analysis? The probable reason for this is that a $95 \%$ confidence level was used as the threshold for statistical significance in the quantitative analysis. With only 16 counties. the strength of the correlation must be very strong to pass this threshold. The quantitative analysis did not contradict any of the descriptive analysis but rather puts the correlation found to be significant on more solid footing.

\section{Findings}

The original reason for aggregating the data at the county level was because of the availability of forest products industry employment and payroll, which were central to my research questions described previously. In general, because there are only sixteen counties in the State of Maine. this is a rather broad analysis of the data although geographical analysis at the municipal level partly compensates for this deficiency.

To summarize the previous section. I determined the following findings:

- Municipalities that supported the Compact in 1996 were significantly likely to support it again in 1997.

- Geographical analysis shows that the main areas of Compact support were located along the densely populated southern coast in York. Cumberland. Sagadahoc and Lincoln Counties. in municipalities hosting large paper making facilities. and in Aroostook county near Caribou. 
- Higher forest products industry employment was associated with opposition to the 1996 Ban Clearcutting option.

- None of the independent variables showed a significant correlation to the 1996 Compact vote.

- Lower population density was associated with support for the 1996 None of the Above option.

- Higher per capita income was associated with support for the Compact in 1997.

\section{Discussion}

The finding that municipal level majority vote for the Compact in 1996 was significantly correlated with majority vote for the Compact again in 1997 is an important one. This is because in the first election there were three choices, a clearcutting ban. a compromise and an option to do nothing. People who voted for the Compact in 1996 had already rejected the clearcutting ban as being too extreme a measure. At the same time newspaper accounts described a fear that a vote for the none of the above option would pull rotes away from the Compact and result in a win for the clearcut ban. But in 1997 voters were only being asked to accept or reject the Compact so voters who worried about helping the clearcut ban by voting for the none of the above option in 1996 were free to vote against the Compact in 1997 . The fact that the majority of voters would opt for the Compact both times in some municipalities indicates a sentiment that it was the best choice all along. What is interesting about this correlation is where the municipalities that voted for the Compact both times are concentrated spatially. The concentrated areas where voters chose the Compact both times are associated with the most urban and least 
forest products industry dependent areas in the state and also. by contrast. in areas with the most highly concentrated forest products industry employment. The research hypothesis was that voters in more urban areas would vote for the clearcut ban rather than the Compact in 1996 and this appears to be true at the county level but is not supported at the municipal level in certain areas. Likewise. another research hypothesis was that higher forest products industry employment would correlate with votes against the clearcut ban. against the Compact and for the none of the above option in 1996 and against the Compact in 1997. Municipal level voting results in many areas do not support this hypothesis. In fact eight out of ten municipalities hosting the largest paper making facilities in the state voted for the Compact in both years. These results indicate that at least part of the pro-Compact voting block was composed of those sympathetic to the forest products industry.

Another interesting result of the vote is the areas where the municipalities voted for the none of the above option in 1996 and against the Compact in 1997 are concentrated spatially. The concentrated areas of core opposition to changes in forestry practices regulation are associated with the most rural and forest products industry dependent areas in the state. These results may also indicate areas where grassroots property rights groups have the most influence or where sentiment against government regulation is the smallest.

The hypothesis that a higher education level correlates with support for the clearcut ban in 96 and support for the Compact in 97 at the county level are supported by the results of descriptive analysis although not at the $95 \%$ confidence level of the quantitative analysis. The conception of this variable is that higher status voters, as 
indicated by higher education levels, can make referendum choices independent of financial considerations. For this reason the prediction was that higher status voters would opt for the ban clearcutting option in 1996 and the Compact in 1997.

The hypothesis that higher per capita income correlates with support for the clearcut ban in 1996 and support for the Compact in 1997 at the county level are also supported by the results of descriptive analysis although the 1996 quantitative analysis did not indicate that per capita income was significant. The 1997 quantitative analysis shows that per capita income was significant at the $95 \%$ confidence level. lending more support to this finding. Similar to level of education, the hypothesis on this variable is based on the conception that higher per capita income indicates higher social status. and that voters with higher status voters would opt for the ban clearcutting option in 1996 and the Compact in 1997. perceiving them as the choices offering the highest level of environmental protection.

The hypothesis that higher population density correlates with support for the clearcut ban in 1996 and support for the Compact in 1997 at the county level and conversely that lower population density correlates with support for the none of the above option are supported by the results of descriptive analysis. Lower population density also showed a significant correlation with support for the 1996 none of the above option at the $95 \%$ confidence level in the quantitative analysis. This variable served as an indication of the "ruralness" of the individual counties. The concept of this variable is that there is a land use ethic and lifestyle associated with rural living which includes a strong sense of individualism. self reliance, and accompanying opposition to government intervention into private land use decisions such as a ban on clearcutting. In this conceptualization. 
voters in more rural areas will vote more on the basis of opposition to new government regulation than voters from more urban areas.

Greater area under LURC jurisdiction only appeared to be correlated with opposition to the clearcut ban in the 1996 descriptive analysis and did not appear significant for both years in the quantitative analysis. For this variable the hypothesis was that voters in counties with greater area under LURC jurisdiction will be more likely to vote against the Compact in 1997. The concept for this variable was that roters in and near areas of extensive LURC jurisdiction will tend to vote against additional state regulation. seeing land use controls in general as a local issue, and a ban on clearcutting as a threat to local economic health.

The variable and its relationship to the 1996 and 1997 votes lie at the core of my thesis. which is that in the 1996 and 1997 referenda. voter preference was largely a function of financial considerations, that is voters in counties that are more economically dependent on the forest products industry were significantly more likely to vote against any regulation that might hinder the industry and cause an accompanying decline in employment. Voters in areas of high industry dependence will tend to "vote with their pocketbooks" and reject regulation that might potentially lessen the individual"s economic prospects. Accordingly the hypotheses were that voters in counties with higher forest products industry employment were more likely to vote against a ban on clearcutting and the Compact and for none of the above options in 1996 and that voters in counties with greater forest products industry employment were more likely to vote against the Compact in 1997. These research hypotheses are supported by descriptive analysis at the county level which showed that the counties most supportive of the 
clearcut ban in 1996 had greater dependent on the forest products industry for employment than counties least supportive of the ban and that counties most supportive of the none of the above option were more dependent on the forest products industry for employment than those counties least supportive of the none of the above option. Higher forest products industry employment was found to be significantly correlated with opposition to the 1996 Ban Clearcutting option in the quantitative analysis.

\section{The Role of the Media in the 1996 and 1997 Elections}

The media certainly played a large role in the 1996 referendum. This role is difficult to quantitatively assess with available data other than the rough measure of total campaign spending and anecdotal accounts. One source placed spending by Jonathan Carter's campaign at $\$ 870,000$ (Greenwire 11/5/98). The Associated Press stated that King. the paper industry and some environmental groups raised in excess of $\$ 5.5$ million dollars to support the compact (Associated Press 1996). Another source placed this figure at $\$ 6$ million (Grenzke. Swope and Carter 1998. 33). The website for Stop the Compact. a property rights group claimed that supporters of the None of the Above option spent $\$ 45.000$ (Stop The Compact 1997). Numerous newspaper sources describe the media campaigns in the final days as being intense.

An alternative explanation to the 1997 vote is in terms of the intluence of the media campaigns of the various forces. Of particular interest in this regard is the account of the 1997 media campaign conducted by anti-Compact forces written by Janet Grenzke. Ken Swope and Jonathan Carter and discussed in more detail in Chapter Four (Grenzke. Swope and Carter 1998). First, they described the Compact defeat as unexpected. 
particularly since it was supported by the powerful forest products industry. The defeat was also unexpected. they explained. because all of the major newspapers supported it and two powerful environmental groups. Maine Audubon and Maine Natural Resource Council, allowed Compact proponents to feature their endorsement in mailings and television commercials (Grenzke et. al. 1998, 2). They attributed what they claimed as their "victory" to a geographically targeted message that carefully avoided areas where a pro-environmental message might cause people to vote for the Compact (Grenzke et. al. 1998. 1). According to the Grenzke. et. al. account. the forest products industry claimed that the Compact would strictly limit clearcutting but certain anti-Compact forces claimed that "...the Compact was 27 pages of technical language and generalities that would have allowed clearcutting to triple..." over the next ten years (Grenzke et. al. 1998. 2). Polling prior to the 1997 Compact vote indicated "confusion" over Compact from conflicting advertisements in the 1996 campaign. where the majority believed that the Compact would reduce clearcutting thus making it the pro-environment choice. This perception by voters was damaging to the anti-Compact forces in the 1997 campaign who felt that the Compact was the anti-environment choice. With this in mind, their strategy was to:

1) Reach a pro-environment base with the "true" information about the Compact (i.e. that it would actually increase clearcutting).

2) Avoid reaching property rights voters who "... were opposed to any kind of government regulation and therefore were already against the Compact" (Grenzke, Swope and Carter. 1998 p.3). 
“...polling data demonstrated that a significant proportion of property rights voters would move from opposing the Compact to supporting the Compact if they heard our message about the Compact allowing more clearcutting" (Grenzke et. al. 1998. 3). "Fortunately, our polling showed that our potential block of environmental voters were mostly in the Portland medial market and in selected coastal zip codes in the Bangor media market. Property-rights and pro-paper corporation voters were most likely in the less populated northern counties of the Bangor media market. This geographic separation allowed us to target our television. radio. mail and Get-Out-The-Vote (GOT) efforts to voters we needed to reach, and to avoid communicating an environmental message which could encourage property rights voters to support the Compact" (Grenzke et. al. 1998. 3). The spatial analysis, which shows the Bangor area as a cluster of Compact opposition generally supports this account.

The anti-Compact forces portrayed the Compact as a trick question in their communications to selected markets containing "pro-environment" voters. They claimed that this is what made the difference in the narrow defeat of the Compact by only at 17.000 vote margin (Grenzke et. al. 1998, 3). As mentioned in Chapter Four it is easier to defeat a referendum than it is to win one, especially if voters are unsure about the benefits and uneasy about the risks, and that was the strategy that anti-Compact forces adopted.

The previous account attributes the outcome to the ironic (and fortunate for antiCompact forces) confluence of property rights group opposition to any regulation and at least some voters being persuaded that the Compact was not the best option for furthering environmental protection. This account also suggests that there is a block of voters 
supportive of the message of grassroots groups who felt that the Compact was inadequate and that a complete clearcut ban was preferable in unincorporated territories.

\section{Conclusion}

The vote was largely about balancing environmental concerns with concerns about economic well being. People in more urban and more affluent areas have greater ability to place more importance on the environmental side of the equation and tend to vote accordingly. This brings up a broader and historically deep rooted debate over who gets to decide how land is used. There also appears to be a general property rights sentiment. often appearing in sparsely populated areas, against additional government regulation that seems to be important enough to influence how people vote.

If you are willing to accept what the literature says about referendum votes li.e. that voters are fickle and can be swayed by last minute media campaigns). and if you are willing to accept the notion that many people vote largely on the basis of their own financial position, the question becomes "Is a referendum an appropriate way to decide such an important issue as how land is used in an area of great ecological. economic and recreational importance?" It also brings up the question of whether the state legislature would be a better place to decide where and how forest industry practices are regulated. The referendum questions put to the voters were simple. but they would approve complex legislation. Most voters did not have the knowledge or motivation to fully understand the implications of the provisions in the text of the legislation or how large a mandate they would be giving the legislature with just one vote. Certainly a more complex set of options could be considered and debated by the legislature than could be responsibly 
presented to voters in a referendum. These options might include public and private nonforest products industry acquisition of tracts of land to remove them from the threat of clearcutting but allow carefully managed multiple use as recommended by the Northern Forest Lands Council. In fact this has already started to occur, although too late to be examined in this research paper. It is unfortunate that such effort was expended by all sided of this issue with no clear result. Despite this. the two referendum votes may have had the effect of encouraging more accountable government. The message to the state legislature is that many people are concerned about the Northern Forest resource and desire change in an important category of land use regulation. This was evidenced by the unexpectedly high voter turnout in 1997. an off-year election. Another positive effect these rotes had was that it made more people aware of the issue of land management and its role in environmental protection. How can the findings of this research be used by planners. land managers and policy makers to protect the environment and allow for multiple uses of the forest resource? It certainly points out the need to be proactive in the development of solutions to land use conflicts before these are decided by a referendum where voters can be readily confused by media campaigns and where the outcome can be determined by voters that are far removed from the economic impact of their decisions. Although they are different from Maine in many respects, this research may help New York. New Hampshire and Vermont, which contain portions of the Northern Forest. assess how changes to forestry regulations will be received by the public. It remains to be seen whether this issue will be presented to Maine voters again in the form of a referendum or whether another solution will be found by planners. land managers and policy makers before this happens. 


\section{Bibliography}

American Planning Association. 1998. Growsmart State Summaries http://planning.org/plnginfo/growsmar/summarv/maine.pdf

Anderson. J.. N. Ciampa. 1997. Ballot Initiatives: recommendations for change. Florida Bar Joumal. $71: 471$

Bishop, B. 1998. A Visit to Maine hup://home navisoft.eom/alliance/ataweb/0896017.htm 1996

Bradbury D. 1996. A Battle for Maine's Forest. Portland Press Herald. Portland. Maine. http://www.portland.com/clearcuthattle.htm 10/24/96

Britannica Online. 1998. United States of America: New England: Maine http://www.eb.com: 180/cgi-bin/g?DocF=macro/5006/47/136.html

Burrough. P. and R. McDonnell. 1998. Principals of Geographical Information Systems. New York: Oxford University Press.

The Center for Business and Economic Research (CBER). 1998. University of Southern Maine. Overall Economic Development Program Supplement. http://www.eddmaine.org/ oedp/foreward.htm

Center for the Defense of Free Enterprise. 1997. The Center's Issues and Positions hutp://www eskimo.com/ ramold/issues.hml

Cronin. T. 1989. Direct Democracy: The Politics of Initiative, Referendum, and Recall. Cambridge. Massachusetts: Harvard University Press.

Dobbs, D. and R. Ober. 1995. The Northern Forest. White River Junction. Vermont: Chelsea Green Publishing Company.

Dwyre, D.. M. O'Gorman. J. Stonecash and R. Young. 1994. Disorganized Politics and the Have-Nots: Politics and Taxes in New York and California. Polity 28:1 45-47.

Ellsworth American. 1998. Compact Defeated www.ellsworthamerican.com/archive/11-697/ea storyl 11-6-97.htm! 11/6/97

Ellsworth American. 1998. Embattled Forest Compact Returns to Ballot Nov. 4 www.ellsworthamerican.com/archive/10-23-97/ea_story2_10-23-97.html 10/23/97

Galvin. T. 1992. States Use Ballot Propositions to Take the Initiative. Politics October, 1992. 
Grenzke. J.. K. Swope and J. Carter. 1998. Case Study: Maine Clear Cut Referendum. Campaigns and Elections 19:4 33-39.

Haugen, L. 1998. Maine Business Online. http://www.mainebusiness.com/list/li72396.htm 1996.

Healy, J.1996. Statistics: A Tool for Social Research. Belmont. California: Wadsworth Publishing Company.

Huber, R. 1998. Maine Greens Struggle against Industrial Forest Owners to Ban Clearcutting in Maine, USA. hut://www.greens.org/maine/gow-me.hml 1996.

Irland, L. 1998. Land. Timber, and Recreation in Maine's Northwoods: Essays by Lloyd C. Irland. Winthrop. Maine: The Irland Group.

Kaiser, E.. D. Godschaik and F. Chapin. 1995. Urban Land L'se Planning. Chicago: University of Illinois Press.

Kekacs, A. 1998. Compact For the Forest. Maine Weekend. hup://wwu. unb.cilenviro/40)5/5maineri.him 8/17/1996.

Klosterman. R. 1990. Community Analysis and Planning Techniques. Maryland: Rowmen and Littlefield Publishers. Inc.

Klyza, C.. S. Trombulak. 1994. The Future of the Northern Forest. Hanover. N.H.: University Press of New England.

Lydenberg. S. 1983. Business Big-Spenders Hit the Referenda Votes. Business and Socien Review. Fall 1983 53-5.

MacManus. S. 1997. Selling School Taxes and Bond Issues to a Generationally Diverse Electorate: Lessons from Florida Referenda. Government Finance Review. 13: 17 22.

Maine Green Party. 1998. 1996 Platform - Natural Resources. hup://wwu mainegreens.org/electgreenpa/platgh/naturep.hum 1996.

Maine Land Use Regulatory Commission. 1998. Homepage http://www.state.me.us/doc/lurc/lurchome.htm

Maine Legislature. 1998. Homepage. http://www.state.me.us/legis/homepage.htm

Maine Office of GIS (OGIS). 1998. Data Catalogue. hup://apollo.ogis.state.me.us/catalog/catalog.htm. 
Maine Office of Policy and Legal Analysis (OPLA). 1998. LD 1892 Enacted Law Summary. hun://weh.dun.uate.me.us/onla/ld1892.htm 1996.

Maine Revised Statutes 12 M.R.S. \$8869. 1997.

Maine Secretary of State. 1997. Maine Citizens Guide to the Referendum Election:

Tuesday, November 5, 1996 http://www.state.me.us/sos/cec/elec/intcon.htm\# 1996.

Maine Secretary of State. 1998. Maine Citizens Guide to the Referendum Election: Tuesday, November 4, 1997. http://www.state me.us/sos/cec/elec/intiony7.hum 1997.

Maine, State of. Bureau of Corporations. Elections and Commissions. Election Division. 1996. General Election Tabulations for the Election of November 5. 1996. Augusta. Maine.

Maine, State of. Bureau of Corporations. Elections and Commissions. Election Division. 1997. General Election Tubulations for the Election of November 4. 1997. Augusta. Maine.

Myers, D. 1992. Analysis with Local Census Data: Portraits of Change. "Chapter 2: Using Census Data for Local Portraits" San Diego, CA: Academic Press Inc.

Northern Forest Lands Council. 1994. Finding Common Ground: Conserving the Northern Forest. Augusta. ME.

Northern Forest Lands Council. 1994. Technical Appendix: A Compendium of Technical Research and Forum Proceedings from the Northern Forest Lands Conncil. Concord. New Hampshire.

Office of Management and Budget (OMB). 1987. Standard Industrial Classification Manual.

Pendall, R., R. Wolanski and D. McGovern. 1997. Property Rights and Property Culture: State Property-Rights Bills and the Districts whose Legislators Support Them. Paper presented at "Planning in the Americas," $39^{\text {th }}$ annual conference of the Association of Collegiate Schools of Planning, Fort Lauderdale, Florida. November, 1998.

Plucker, J. 1998. Tyrany of the Many http://w ww unc mainc.edu/ cofed/news/newstyrr.html 1996.

Poitras. J. 1998. Clearcut Ban Would Cripple Maine. http://www.unh.ca/enviro/4005/5mainerf.htm 7/4/1996. 
Publius Research. 1998. Maine Statistical Abstract: A profile of the State. http://gray.maine.com/shops/publius/mestabs.htm

Pulp and Paper, January $19971: 7121$

Schmidt, D. 1989. Citizen Lawmakers Philadelphia: Temple University Press.

Settler's Advocate. 1998. Common Sense from New York and New England http:/home/navisoft.com/alliance/afaweb/1096002.htm 10/3/96.

Stop The Compact. 1998. http://www.stopcompact.com/origin.html 1997.

Tokar. B. 1995. The "Wise Use" Backlash: Responding to Militant AntiEnvironmentalism. Ecology 25:4 150-156.

US Bureau of the Census. 1996. USA Comnties 1996 General Profile.

US Bureau of Census. 1995. USA Comnties 1995 Economic Profile.

US Bureau of Census. 1998. General Explanation of Countr Business Pattems Data http://www.census.gov/epcd/cbp/view/genexpl.int

Whitney, Robert, Executive Vice President. Landvest. Inc. 1999. Personal Correspondence 
Appendix A

Maine 1995 Employment and Payroll by County 
Appendix A: Maine 1995 Employment and Payroll by County

\begin{tabular}{|c|c|c|c|c|c|c|c|c|}
\hline County & SIC Codes and Category Titles & "Employees & $\begin{array}{l}\text { "Annual } \\
\text { Payroll } \\
\text { (Dollars) } \\
\end{array}$ & $\begin{array}{c}\text { Employment } \\
\text { as } \% \text { of } \\
\text { county total }\end{array}$ & $\begin{array}{c}\text { Payroll } \\
\text { as } \% \text { of } \\
\text { county total } \\
\end{array}$ & $\begin{array}{c}\text { Employment } \\
\text { as } \% \text { of } \\
\text { Maine total } \\
\end{array}$ & $\begin{array}{l}\text { Payroll } \\
\text { as \% of } \\
\text { Maine total }\end{array}$ & $\begin{array}{c}\text { Employment } \\
\text { Percent of } \\
\text { Manufacturing Sector }\end{array}$ \\
\hline \multirow[t]{15}{*}{ Androscoggin } & 07: Ag Services, Forestry, and Fishing & 121 & $2,550,000$ & 0.3 & 0.3 & 4.6 & 4.5 & \\
\hline & 0800: forestry & 0 & of & 0.0 & 0.0 & 0.0 & 0.0 & \\
\hline & 10: Mining & 10 & nd & 0.0 & nd & 14.9 & nd & \\
\hline & 15: Construction & 1,732 & $44,060,000$ & 4.4 & 5.5 & 8.9 & 8.2 & \\
\hline & 20: Manufacturing & 9,411 & $227,740,000$ & 23.9 & 28.4 & 10.4 & 8.5 & \\
\hline & 2400: lumber and wood products & 637 & $14,470,000$ & 1.6 & 1.8 & 5.5 & 5.7 & 6.8 \\
\hline & 2410: Logging & 77 & $1,100,000$ & 0.2 & 0.1 & 2.2 & 1.4 & \\
\hline & 2600: paper and allied products & 813 & $24,600,000$ & 2.1 & 3.1 & 5.9 & 32.3 & 8.6 \\
\hline & 40: Transportation and Public Utitities & 1,385 & $34,680,000$ & 3.5 & 4.3 & 7.0 & 6.1 & \\
\hline & 50: Wholesale Trade & 2,388 & $57,640,000$ & 6.1 & 7.2 & 9.5 & 8.4 & \\
\hline & 52: Retail Trade & 8,082 & $105,960,000$ & 20.5 & 13.2 & 7.8 & 7.2 & \\
\hline & 60: Finance, Insurance and Real Estate & 2,027 & $50,860,000$ & 5.1 & 6.3 & 7.9 & 6.8 & \\
\hline & 70: Services & 14,263 & $278,660,000$ & 36.2 & 34.7 & 9.8 & 9.1 & \\
\hline & 99: Unclassified Establishments & 60 & nd & 0.2 & nd & 15.7 & nd & \\
\hline & Total & 39,431 & $802,400,000$ & 100.0 & 100.0 & 9.1 & 8.2 & \\
\hline \multirow[t]{15}{*}{ Aroostook } & 07: Ag Services, Forestry, and Fishing & 203 & $3,040,000$ & 0.9 & 7.1 & 7.7 & 5.4 & \\
\hline & 0800: forestry & 60 & & 0.3 & nd & 22.2 & nd & \\
\hline & 10: Mining & 10 & nd & 0.0 & nd & 14.9 & nd & \\
\hline & 15: Construction & 743 & $19,300,000$ & 3.3 & 45.0 & 3.8 & 3.6 & \\
\hline & 20: Manufacturing & 4,714 & $135,730,000$ & 20.8 & 316.8 & 5.2 & 5.1 & \\
\hline & 2400: lumber and wood products & 1,969 & $43,690,000$ & 8.7 & 102.0 & 17.1 & 17.2 & 41.8 \\
\hline & 2410: Logging & 834 & $15,570,000$ & 3.7 & 36.3 & 24.2 & 20.5 & \\
\hline & 2600: paper and allied products & 1,750 & nd & 7.7 & nd & 12.7 & nd & 37.1 \\
\hline & 40: Transportation and Public Utilities & 1,479 & $30,870,000$ & 6.5 & 72.0 & 7.5 & 5.5 & \\
\hline & 50: Wholesale Trade & 1,091 & $22,480,000$ & 4.8 & 52.5 & 4.4 & 3.3 & \\
\hline & 52: Retail Trade & 5,676 & $64,050,000$ & 25.1 & 149.5 & 5.5 & 4.4 & \\
\hline & 60: Finance, Insurance and Real Estate & 965 & $19,570,000$ & 4.3 & 45.7 & 3.8 & 2.6 & \\
\hline & 70: Services & 7,740 & $133,290,000$ & 34.2 & 311.1 & 5.3 & 4.4 & \\
\hline & 99: Unclassified Establishments & 10 & & 0.0 & nd & 2.6 & nd & \\
\hline & Total & 22,624 & $42,850,000$ & 100.0 & 100.0 & 5.2 & 0.4 & \\
\hline
\end{tabular}


Appendix A: Maine 1995 Employment and Payroll by County

\begin{tabular}{|c|c|c|c|c|c|c|c|c|}
\hline County & SIC Codes and Category Titles & "Employees & $\begin{array}{l}\text { Annual } \\
\text { Payroll } \\
\text { (Dollars) }\end{array}$ & $\begin{array}{c}\text { Employment } \\
\text { as } \% \text { of } \\
\text { county total } \\
\end{array}$ & $\begin{array}{c}\text { Payroll } \\
\text { as } \% \text { of } \\
\text { county total }\end{array}$ & $\begin{array}{c}\text { Employment } \\
\text { as \% of } \\
\text { Maine total }\end{array}$ & $\begin{array}{c}\text { Payroll } \\
\text { as \% of } \\
\text { Maine total }\end{array}$ & $\begin{array}{c}\text { Employment } \\
\text { Percent of } \\
\text { Manufacturing Sector }\end{array}$ \\
\hline \multirow[t]{15}{*}{ Cumberland } & Cumberland & Cumberland & Cumberland & Cumberland & Cumberland & Cumberland & Cumberland & Cumberland \\
\hline & 0800: foresiry & 9 & 140,000 & 0.0 & 0.0 & 3.3 & 2.3 & \multirow{14}{*}{11.3} \\
\hline & 10: Mining & 17 & 350,000 & 0.0 & 0.0 & 25.4 & 21.0 & \\
\hline & 15: Construction & 5,113 & $149,420,000$ & 4.0 & 4.6 & 26.4 & 27.7 & \\
\hline & 20: Manufacturing & 15,473 & $505,480,000$ & 12.0 & 15.7 & 17.1 & 18.9 & \\
\hline & 2400: lumber and wood products & 622 & $12,910,000$ & 0.5 & 0.4 & 5.4 & 5.1 & \\
\hline & 2410: Logging & 56 & 920,000 & 0.0 & 0.0 & 1.6 & 1.2 & \\
\hline & 2600: paper and allied products & 1,750 & nd & 1.4 & & 12.7 & nd & \\
\hline & 40: Transportation and Public Utilities & 5,917 & $191,770,000$ & 4.6 & 5.9 & 29.9 & 34.0 & \\
\hline & 50: Wholesale Trade & 10,388 & $312,610,000$ & 8.1 & 9.7 & 41.5 & 45.8 & \\
\hline & 52: Retail Trade & 31,075 & $494,820,000$ & 24.1 & 15.3 & 30.0 & 33.8 & \\
\hline & 60: Finance, Insurance and Real Estate & 13,669 & $472,710,000$ & 10.6 & 14.6 & 53.5 & 62.9 & \\
\hline & 70: Services & 46,387 & $1,078,580,000$ & 36.0 & 33.4 & 31.9 & 35,3 & \\
\hline & 99: Unclassified Establishments & 88 & $4,370,000$ & 0.1 & 0.1 & 23.0 & 53.0 & \\
\hline & Total & 128,127 & $3,210,110,000$ & 100.0 & 100.0 & 29.8 & 32.9 & \\
\hline \multirow[t]{15}{*}{ Franklin } & 07: Ag Services, Forestry, and Fishing & 60 & 120,000 & 0.5 & 0.1 & 2.3 & 0.2 & \multirow{15}{*}{18.3} \\
\hline & 0800: forestry & 10 & nd & 0.1 & nd & 3.7 & nd & \\
\hline & 10: Mining & 10 & nd & 0.1 & nd & 14.9 & nd & \\
\hline & 15: Construction & 306 & $7,620,000$ & 2.8 & 3.5 & 1.6 & 1.4 & \\
\hline & 20: Manufacturing & 4,006 & $125,470,000$ & 36.6 & 56.9 & 4.4 & 4.7 & \\
\hline & 2400: lumber and wood products & 735 & $16,380,000$ & 6.7 & 7.4 & 6.4 & 6.4 & \\
\hline & 2410: Logging & 205 & 3,370 & 1.9 & 0.0 & 6.0 & 0.0 & \\
\hline & 2600: paper and allied products & 1,750 & nd & 16.0 & nd & 12.7 & nd & \\
\hline & 40: Transportation and Public Utilities & 294 & $7,090,000$ & 2.7 & 3.2 & 1.5 & 1.3 & \\
\hline & 50: Wholesale Trade & 138 & $3,490,000$ & 1.3 & 1.6 & 0.6 & 0.5 & \\
\hline & 52: Retail Trade & 2,508 & $26,350,000$ & 22.9 & 11.9 & 2.4 & 1.8 & \\
\hline & 60: Finance, Insurance and Real Estate & 440 & $8,950,000$ & 4.0 & 4.1 & 1.7 & 1.2 & \\
\hline & 70: Services & 3,170 & $40,290,000$ & 29.0 & 18.3 & 2.2 & 1.3 & \\
\hline & 99: Unclassified Establishments & 10 & & 0.1 & nd & 2.6 & nd & \\
\hline & Total & 10,939 & $220,670,000$ & 100.0 & 100.0 & 2.5 & 2.3 & \\
\hline
\end{tabular}


Appendix A: Maine 1995 Employment and Payroll by County

\begin{tabular}{|c|c|c|c|c|c|c|c|c|}
\hline County & SIC Codes and Category Titles & *Employees & $\begin{array}{l}\text { "Annual } \\
\text { Payroll } \\
\text { (Dollars) }\end{array}$ & $\begin{array}{l}\text { Employment } \\
\text { as } \% \text { of } \\
\text { county total }\end{array}$ & $\begin{array}{c}\text { Payroll } \\
\text { as } \% \text { of } \\
\text { county total }\end{array}$ & $\begin{array}{c}\text { Employment } \\
\text { as } \% \text { of } \\
\text { Maine total }\end{array}$ & $\begin{array}{c}\text { Payroll } \\
\text { as \% of } \\
\text { Maine total }\end{array}$ & $\begin{array}{c}\text { Employment } \\
\text { Percent of } \\
\text { Manufacturing Sector }\end{array}$ \\
\hline \multirow[t]{15}{*}{ Hancock } & 07: Ag Services, Forestry, and Fishing & 136 & $3.090,000$ & 0.9 & 1.0 & 5.2 & 5.5 & \\
\hline & 0800: forestry & 24 & 210,000 & 0.2 & 0.1 & 8.9 & 3.5 & \\
\hline & 10: Mining & 10 & nd & 0.1 & nd & 14.9 & nd & \\
\hline & 15: Construction & 1,243 & $27,030,000$ & 8.7 & 8.3 & 6.4 & 5.0 & \\
\hline & 20: Manufacturing & 2,665 & $88,960,000$ & 18.6 & 27.4 & 2.9 & 3.3 & \\
\hline & 2400: lumber and wood products & 149 & $5,140,000$ & 1.0 & 1.6 & 1.3 & 2.0 & 5.6 \\
\hline & 2410: Logging & 111 & $4,570,000$ & 0.8 & 1.4 & 3.2 & 6.0 & \\
\hline & 2600: paper and allied products & 1,750 & nd & 12.2 & nd & 12.7 & nd & 65.7 \\
\hline & 40: Transportation and Public Utilities & 582 & $12,780,000$ & 4.1 & 3.9 & 2.9 & 2.3 & \\
\hline & 50: Wholesale Trade & 465 & $10,350,000$ & 3.2 & 3.2 & 1.9 & 1.5 & \\
\hline & 52: Retail Trade & 3,639 & $57,870,000$ & 25.4 & 17.8 & 3.5 & 4.0 & \\
\hline & 60: Finance, Insurance and Real Estate & 716 & $17,950,000$ & 5.0 & 5.5 & 2.8 & 2.4 & \\
\hline & 70: Services & 4,861 & $106,000,000$ & 33.9 & 32.7 & 3.3 & 3.5 & \\
\hline & 99: Unclassified Establishments & 60 & $\mathrm{nd}$ & 0.4 & $r$ & $15 \cdots$ & nd & \\
\hline & Total & 14,338 & $324,400,000$ & 100.0 & 100.0 & 3.3 & 3.3 & \\
\hline \multirow[t]{15}{*}{ Kennebec } & 07: Ag Services, Forestry, and Fishing & 236 & $3,750,000$ & 0.6 & 0.4 & 8.9 & 6.6 & \\
\hline & 0800 : forestry & 60 & & 0.1 & nd & 22.2 & nd & \\
\hline & 10: Mining & 10 & & 0.0 & nd & 14.9 & nd & \\
\hline & 15: Construction & 1,644 & $46,470,000$ & 4.1 & 5.2 & 8.5 & 8.6 & \\
\hline & 20: Manufacturing & 6,366 & $194,840,000$ & 15.8 & 21.7 & 7.0 & 7.3 & \\
\hline & 2400: lumber and wood products & 409 & $11,350,000$ & 1.0 & 1.3 & 3.6 & 4.5 & 6.4 \\
\hline & 2410: Logging & 297 & $9,410,000$ & 0.7 & 1.0 & 8.6 & 12.4 & \\
\hline & 2600: paper and allied products & 991 & $47,470,000$ & 2.5 & 5.3 & 7.2 & 62.4 & 15.6 \\
\hline & 40: Transportation and Public Utilities & 1,976 & $59,930,000$ & 4.9 & 6.7 & 10.0 & 10.6 & \\
\hline & 50: Wholesale Trade & 2,559 & $68,670,000$ & 6.4 & 7.6 & 10.2 & 10.1 & \\
\hline & 52: Retail Trade & 10,111 & $134,210,000$ & 25.1 & 14.9 & 9.8 & 9.2 & \\
\hline & 60: Finance, Insurance and Real Estate & 1,669 & $40,530,000$ & 4.1 & 4.5 & 6.5 & 5.4 & \\
\hline & 70: Services & 15,681 & $348,210,000$ & 39.0 & 38.8 & 10.8 & 11.4 & \\
\hline & 99: Unclassified Establishments & 60 & & 0.1 & nd & 15.7 & nd & \\
\hline & Total & 40,229 & $897,890,000$ & 100.0 & 100.0 & 9.3 & 9.2 & \\
\hline
\end{tabular}




\section{Appendix A: Maine 1995 Employment and Payroll by County}

\begin{tabular}{|c|c|c|c|c|c|c|c|c|}
\hline County & SIC Codes and Category Titles & Employees & $\begin{array}{l}\text { "Annual } \\
\text { Payroll } \\
\text { (Dollars) }\end{array}$ & $\begin{array}{c}\text { Employment } \\
\text { as } \% \text { of } \\
\text { county total }\end{array}$ & $\begin{array}{c}\text { Payroll } \\
\text { as } \% \text { of } \\
\text { county total } \\
\end{array}$ & $\begin{array}{c}\text { Employment } \\
\text { as } \% \text { of } \\
\text { Maine total } \\
\end{array}$ & $\begin{array}{c}\text { Payroll } \\
\text { as \% of } \\
\text { Maine total }\end{array}$ & $\begin{array}{c}\text { Employment } \\
\text { Percent of } \\
\text { Manufacturing Sector }\end{array}$ \\
\hline \multirow[t]{15}{*}{ Knox } & 07: Ag Services, Forestry, and Fishing & 142 & 330,000 & 1.1 & 0.1 & 5.4 & 0.6 & \\
\hline & 0800 : forestry & 0 & 0 & 0.0 & 0.0 & 0.0 & 0.0 & \\
\hline & 10: Mining & 0 & 0 & 0.0 & 0.0 & 0.0 & 0.0 & \\
\hline & 15: Construction & 742 & $17,210,000$ & 5.7 & 6.4 & 3.8 & 3.2 & \\
\hline & 20: Manufacturing & 2,483 & $5,540,000$ & 19.0 & 2.0 & 2.7 & 0.2 & \\
\hline & 2400: lumber and wood products & 60 & nd & 0.5 & nd & 0.5 & nd & 2.4 \\
\hline & 2410: Logging & 3 & 60,000 & 0.0 & 0.0 & 0.1 & 0.1 & \\
\hline & 2600: paper and allied products & 0 & 0 & 0.0 & 0.0 & 0.0 & 0.0 & 0.0 \\
\hline & 40: Transportation and Public Utilities & 529 & $12,760,000$ & 4.0 & 4.7 & 2.7 & 2.3 & \\
\hline & 50: Wholesale Trade & 803 & $19,100,000$ & 6.1 & 7.1 & 3.2 & 2.8 & \\
\hline & 52: Retail Trade & 3,084 & $44,380,000$ & 23.6 & 16.4 & 3.0 & 3.0 & \\
\hline & 60: Finance, Insurance and Real Estate & 404 & $9,810,000$ & 3.1 & 3.6 & 1.6 & 1.3 & \\
\hline & 70: Services & 4,895 & $108,370,000$ & 37.4 & 40.1 & 3.4 & 3.5 & \\
\hline & 99: Unclassified Establishments & 10 & 140.000 & 0.1 & 0.1 & 2.6 & 1.7 & \\
\hline & Total & 13,092 & $270,480,000$ & 100.0 & 100.0 & 3.0 & 2.8 & \\
\hline \multirow[t]{15}{*}{ Lincoln } & 07: Ag Services, Forestry, and Fishing & 50 & $1,380,000$ & 0.7 & 0.9 & 1.9 & 2.4 & \\
\hline & 0800: forestry & 10 & & 0.1 & nd & 3.7 & nd & \\
\hline & 10: Mining & 10 & nd & 0.1 & nd & 14.9 & nd & \\
\hline & 15: Construction & 452 & $9,000,000$ & 6.6 & 5.9 & 2.3 & 1.7 & \\
\hline & 20: Manufacturing & 788 & $18,640,000$ & 11.4 & 12.2 & 0.9 & 0.7 & \\
\hline & 2400: lumber and wood products & 25 & 300,000 & 0.4 & 0.2 & 0.2 & 0.1 & 3.2 \\
\hline & 2410: Logging & 10 & nd & 0.1 & nd & 0.3 & nd & \\
\hline & 2600: paper and allied products & 0 & 0 & 0.0 & 0.0 & 0.0 & 0.0 & 0.0 \\
\hline & 40: Transportation and Public Utilities & 632 & $34,450,000$ & 9.2 & 22.5 & 3.2 & 6.1 & \\
\hline & 50: Wholesale Trade & 256 & $4,820,000$ & 3.7 & 3.1 & 1.0 & 0.7 & \\
\hline & 52: Retail Trade & 2,135 & $30,990,000$ & 31.0 & 20.2 & 2.1 & 2.1 & \\
\hline & 60: Finance, Insurance and Real Estate & 337 & $8,230,000$ & 4.9 & 5.4 & 1.3 & 1.1 & \\
\hline & 70: Services & 2,218 & $44,990,000$ & 32.2 & 29.4 & 1.5 & 1.5 & \\
\hline & 99: Unclassified Establishments & 10 & nd & 0.1 & nd & 2.6 & nd & \\
\hline & Total & 6,886 & $153,230,000$ & 100.0 & 100.0 & 1.6 & 1.6 & \\
\hline
\end{tabular}


Appendix A: Maine 1995 Employment and Payroll by County

\begin{tabular}{|c|c|c|c|c|c|c|c|c|}
\hline County & SIC Codes and Category Titles & "Employees & $\begin{array}{l}\text { "Annual } \\
\text { Payroll } \\
\text { (Dollars) }\end{array}$ & $\begin{array}{c}\text { Employment } \\
\text { as } \% \text { of } \\
\text { county total }\end{array}$ & $\begin{array}{c}\text { Payroll } \\
\text { as \% of } \\
\text { county total }\end{array}$ & $\begin{array}{c}\text { Employment } \\
\text { as \% of } \\
\text { Maine total }\end{array}$ & $\begin{array}{c}\text { Payroll } \\
\text { as \% of } \\
\text { Maine total }\end{array}$ & $\begin{array}{c}\text { Employment } \\
\text { Percent of } \\
\text { Manufacturing Sector }\end{array}$ \\
\hline \multirow[t]{15}{*}{ Oxford } & 07: Ag Services, Forestry, and Fishing & 86 & $1,420,000$ & 0.6 & 0.5 & 3.3 & 2.5 & \\
\hline & 0800: forestry & 10 & nd & 0.1 & nd & 3.7 & nd & \\
\hline & 10: Mining & 10 & nd & 0.1 & nd & 14.9 & nd & \\
\hline & 15: Construction & 535 & $13,020,000$ & 3.7 & 4.5 & 2.8 & 2.4 & \\
\hline & 20: Manufacturing & 4,336 & $128,060,000$ & 30.1 & 43.8 & 4.8 & 4.8 & \\
\hline & 2400: lumber and wood products & 1,829 & $36,260,000$ & 12.7 & 12.4 & 15.9 & 14.2 & 42.2 \\
\hline & 2410: Logging & 261 & $4,790,000$ & 1.8 & 1.6 & 7.6 & 6.3 & \\
\hline & 2600: paper and allied products & 1,750 & nd & 12.2 & nd & 12.7 & nd & 40.4 \\
\hline & 40: Transportation and Public Utilities & 678 & $13,330,000$ & 4.7 & 4.6 & 3.4 & 2.4 & \\
\hline & 50: Wholesale Trade & 458 & $10,940,000$ & 3.2 & 3.7 & 1.8 & 1.6 & \\
\hline & 52: Retail Trade & 2,769 & $34,290,000$ & 19.3 & 11.7 & 2.7 & 2.3 & \\
\hline & 60: Finance, Insurance and Real Estate & 516 & $11,160,000$ & 3.6 & 3.8 & 2.0 & 1.5 & \\
\hline & 70: Services & 4,995 & $79,850,000$ & 34.7 & 27.3 & 3.4 & 2.6 & \\
\hline & 99: Unclassified Establishments & 10 & & 0.1 & nd & 2.6 & nd & \\
\hline & Total & 14,383 & $292,370,000$ & & & 3.3 & 3.0 & \\
\hline \multirow[t]{15}{*}{ Penobscot } & 07: Ag Services, Forestry, and Fishing & 277 & $5,800,000$ & 0.5 & 0.5 & 10.5 & 10.3 & \\
\hline & 0800: forestry & 97 & $3,070,000$ & 0.2 & 0.3 & 35.9 & 51.0 & \\
\hline & 10: Mining & 10 & & 0.0 & nd & 14.9 & nd & \\
\hline & 15: Construction & 1.977 & $63,590,000$ & 3.8 & 5.4 & 10.2 & 11.8 & \\
\hline & 20: Manufacturing & 10,284 & $297,260,000$ & 19.6 & 25.1 & 11.4 & 11.1 & \\
\hline & 2400: lumber and wood products & 1,553 & $37,080,000$ & 3.0 & 3.1 & 13.5 & 14.6 & 15.1 \\
\hline & 2410: Logging & 688 & $16,540,000$ & 1.3 & 1.4 & 20.0 & 21.7 & \\
\hline & 2600: paper and allied products & 3,111 & $125,390,000$ & 5.9 & 10.6 & 22.7 & 164.9 & 30.3 \\
\hline & 40: Transportation and Public Utilities & 3,557 & $101,950,000$ & 6.8 & 8.6 & 18.0 & 18.1 & \\
\hline & 50: Wholesale Trade & 3,418 & $94,590,000$ & 6.5 & 8.0 & 13.7 & 13.9 & \\
\hline & 52: Retail Trade & 13,110 & $174,870,000$ & 24.9 & 14.8 & 12.7 & 11.9 & \\
\hline & 60: Finance, Insurance and Real Estate & 2,035 & $50,540,000$ & 3.9 & 4.3 & 8.0 & 6.7 & \\
\hline & 70: Services & 17,875 & $395,290,000$ & 34.0 & 33.4 & 12.3 & 12.9 & \\
\hline & 99: Unclassified Establishments & 60 & & 0.1 & nd & 15.7 & nd & \\
\hline & Total & 52,579 & $1,184,330,000$ & 100.0 & 100.0 & 12.2 & 12.1 & \\
\hline
\end{tabular}


Appendix A: Maine 1995 Employment and Payroll by County

\begin{tabular}{|c|c|c|c|c|c|c|c|c|}
\hline County & SIC Codes and Category Titles & "Employees & $\begin{array}{l}\text { "Annual } \\
\text { Payroll } \\
\text { (Dollars) }\end{array}$ & $\begin{array}{c}\text { Employment } \\
\text { as } \% \text { of } \\
\text { county total }\end{array}$ & $\begin{array}{c}\text { Payroll } \\
\text { as } \% \text { of } \\
\text { county total }\end{array}$ & $\begin{array}{c}\text { Employment } \\
\text { as \% of } \\
\text { Maine total }\end{array}$ & $\begin{array}{c}\text { Payroll } \\
\text { as } \% \text { of } \\
\text { Maine total }\end{array}$ & $\begin{array}{c}\text { Employment } \\
\text { Percent of } \\
\text { Manufacturing Sector }\end{array}$ \\
\hline \multirow[t]{15}{*}{ Piscataquis } & 07: Ag Services, Forestry, and Fishing & 28 & 640,000 & 0.6 & 0.7 & 1.1 & 1.1 & \\
\hline & 0800: forestry & 6 & 110,000 & 0.1 & 0.1 & 2.2 & 1.8 & \\
\hline & 10: Mining & 10 & nd & 0.2 & nd & 14.9 & nd & \\
\hline & 15: Construction & 114 & $4,110,000$ & 2.5 & 4.6 & 0.6 & 0.8 & \\
\hline & 20: Manufacturing & 1,799 & $41,500,000$ & 38.8 & 46.3 & 2.0 & 1.5 & \\
\hline & 2400: lumber and wood products & 842 & $17,050,000$ & 18.1 & 19.0 & 7.3 & 6.7 & 46.8 \\
\hline & 2410: Logging & 134 & $2,690,000$ & 2.9 & 3.0 & 3.9 & 3.5 & \\
\hline & 2600: paper and allied products & 0 & 0 & 0.0 & 0.0 & 0.0 & 0.0 & 0.0 \\
\hline & 40: Transportation and Public Utilities & 165 & $4,030,000$ & 3.6 & 4.5 & 0.8 & 0.7 & \\
\hline & 50: Wholesale Trade & 86 & $1,330,000$ & 1.9 & 1.5 & 0.3 & 0.2 & \\
\hline & 52: Retail Trade & 1,115 & $13,460,000$ & 24.0 & 15.0 & 1.1 & 0.9 & \\
\hline & 60: Finance, Insurance and Real Estate & 112 & $2,090,000$ & 2.4 & 2.3 & 0.4 & 0.3 & \\
\hline & 70: Services & 1,216 & $22,460,000$ & 26.2 & 25.0 & 0.8 & 0.7 & \\
\hline & 99: Unclassified Establishments & 10 & nd & 0.2 & nd & 2.6 & nd & \\
\hline & Total & 4,641 & $89,700,000$ & 100.0 & 100.0 & 1.1 & 0.9 & \\
\hline \multirow[t]{15}{*}{ Sagadahoc } & 07: Ag Services, Forestry, and Fishing & 42 & 720,000 & 0.3 & 0.2 & 1.6 & 1.3 & \\
\hline & 0800 : forestry & 0 & & 0.0 & 0.0 & 0.0 & 0.0 & \\
\hline & 10: Mining & 10 & 0 & 0.1 & 0.0 & 14.9 & 0.0 & \\
\hline & 15: Construction & 488 & $15,460,000$ & 3.4 & 3.8 & 2.5 & 2.9 & \\
\hline & 20: Manufacturing & 7,500 & nd & 51.8 & nd & 8.3 & nd & \\
\hline & 2400: lumber and wood products & 10 & nd & 0.1 & nd & 0.1 & nd & 0.1 \\
\hline & 2410: Logging & 10 & nd & 0.1 & nd & 0.3 & nd & \\
\hline & 2600: paper and allied products & 0 & 0 & 0.0 & 0.0 & 0.0 & 0.0 & 0.0 \\
\hline & 40: Transportation and Public Utilities & 232 & $5,130,000$ & 1.6 & 1.2 & 1.2 & 0.9 & \\
\hline & 50: Wholesale Trade & 135 & $2,500,000$ & 0.9 & 0.6 & 0.5 & 0.4 & \\
\hline & 52: Retail Trade & 1,750 & nd & 12.1 & nd & 1.7 & nd & \\
\hline & 60: Finance, Insurance and Real Estate & 253 & $5,670,000$ & 1.7 & 1.4 & 1.0 & 0.8 & \\
\hline & 70: Services & 2,132 & $43,110,000$ & 14.7 & 10.5 & 1.5 & 1.4 & \\
\hline & 99: Unclassified Establishments & 10 & nd & 0.1 & nd & 2.6 & nd & \\
\hline & Total & 14,469 & $411,870,000$ & 100.0 & 100.0 & 3.3 & 4.2 & \\
\hline
\end{tabular}




\section{Appendix A: Maine 1995 Employment and Payroll by County}

\begin{tabular}{|c|c|c|c|c|c|c|c|c|}
\hline County & SIC Codes and Category Titles & *Employees & $\begin{array}{l}\text { "Annual } \\
\text { Payroll } \\
\text { (Dollars) }\end{array}$ & $\begin{array}{c}\text { Employment } \\
\text { as } \% \text { of } \\
\text { county total }\end{array}$ & $\begin{array}{c}\text { Payroll } \\
\text { as \% of } \\
\text { county total }\end{array}$ & $\begin{array}{c}\text { Employment } \\
\text { as \% of } \\
\text { Maine total }\end{array}$ & $\begin{array}{c}\text { Payroll } \\
\text { as } \% \text { of } \\
\text { Maine total } \\
\end{array}$ & $\begin{array}{c}\text { Employment } \\
\text { Percent of } \\
\text { Manufacturing Sector }\end{array}$ \\
\hline \multirow[t]{15}{*}{ Somerset } & 07: Ag Services, Forestry, and Fishing & 77 & $3,080,000$ & 0.5 & 0.9 & 2.9 & 5.5 & \\
\hline & 0800: forestry & 10 & nd & 0.1 & nd & 3.7 & nd & \\
\hline & 10: Mining & 10 & nd & 0.1 & nd & 14.9 & nd & \\
\hline & 15: Construction & 1,544 & $58,110,000$ & 10.7 & 16.8 & 8.0 & 10.8 & \\
\hline & 20: Manufacturing & 4,683 & $143,890,000$ & 32.5 & 41.5 & 5.2 & 5.4 & \\
\hline & 2400: lumber and wood products & 1,603 & $31,410,000$ & 11.1 & 9.1 & 13.9 & 12.3 & 34.2 \\
\hline & 2410: Logging & 531 & $12,410,000$ & 3.7 & 3.6 & 15.4 & 16.3 & \\
\hline & 2600: paper and allied products & 1,750 & nd & 12.1 & nd & 12.7 & nd & 37.4 \\
\hline & 40: Transportation and Public Utilities & 650 & $16.110,000$ & 4.5 & 4.7 & 3.3 & 2.9 & \\
\hline & 50: Wholesale Trade & 747 & $20,610,000$ & 5.2 & 6.0 & 3.0 & 3.0 & \\
\hline & 52: Retail Trade & 2,827 & $36,790,000$ & 19.6 & 10.6 & 2.7 & 2.5 & \\
\hline & 60: Finance, Insurance and Real Estate & 407 & $8,120,000$ & 2.8 & 2.3 & 1.6 & 1.1 & \\
\hline & 70: Services & 3,466 & $59,430,000$ & 24.0 & 17.2 & 2.4 & 1.9 & \\
\hline & 99: Unclassified Establishments & 10 & nd & 0.1 & nd & 2.6 & nd & \\
\hline & Total & 14,414 & $346,380,000$ & 100.0 & 100.0 & 3.3 & 3.5 & \\
\hline \multirow[t]{15}{*}{ Waldo } & 07: Ag Services, Forestry, and Fishing & 29 & 420,000 & 0.5 & 0.4 & 1.1 & 0.7 & \\
\hline & 0800: forestry & 0 & & 0.0 & 0.0 & 0.0 & 0.0 & \\
\hline & 10: Mining & 0 & & 0.0 & 0.0 & 0.0 & 0.0 & \\
\hline & 15: Construction & 334 & $6,840,000$ & 5.8 & 7.1 & 1.7 & 1.3 & \\
\hline & 20: Manufacturing & 1,750 & nd & 30.3 & nd & 1.9 & nd & \\
\hline & 2400: lumber and wood products & 266 & $6,480,000$ & 4.6 & 6.7 & 2.3 & 2.5 & 15.2 \\
\hline & 2410: Logging & 20 & 200,000 & 0.3 & 0.2 & 0.6 & 0.3 & \\
\hline & 2600: paper and allied products & 10 & nd & 0.2 & nd & 0.1 & nd & 0.6 \\
\hline & 40: Transportation and Public Utilities & 313 & $5,280,000$ & 5.4 & 5.4 & 1.6 & 0.9 & \\
\hline & 50: Wholesale Trade & 151 & $3,990,000$ & 2.6 & 4.1 & 0.6 & 0.6 & \\
\hline & 52: Retail Trade & 1,750 & nd & 30.3 & nd & 1.7 & nd & \\
\hline & 60: Finance, Insurance and Real Estate & 151 & $2,870,000$ & 2.6 & 3.0 & 0.6 & 0.4 & \\
\hline & 70: Services & 1,893 & $29,990,000$ & 32.7 & 30.9 & 1.3 & 1.0 & \\
\hline & 99: Unclassified Establishments & & 90,000 & 0.1 & 0.1 & 1.8 & 1.1 & \\
\hline & Total & 5,783 & $97,020,000$ & 100.0 & 100.0 & 1.3 & 1.0 & \\
\hline
\end{tabular}


Appendix A: Maine 1995 Employment and Payroll by County

\begin{tabular}{|c|c|c|c|c|c|c|c|c|}
\hline County & SIC Codes and Category Titles & "Employees & $\begin{array}{l}\text { "Annual } \\
\text { Payroll } \\
\text { (Dollars) }\end{array}$ & $\begin{array}{l}\text { Employment } \\
\text { as } \% \text { of } \\
\text { county total }\end{array}$ & $\begin{array}{c}\text { Payroll } \\
\text { as } \% \text { of } \\
\text { county total }\end{array}$ & $\begin{array}{c}\text { Employment } \\
\text { as \% of } \\
\text { Maine total }\end{array}$ & $\begin{array}{c}\text { Payroll } \\
\text { as \% of } \\
\text { Maine total }\end{array}$ & $\begin{array}{c}\text { Employment } \\
\text { Percent of } \\
\text { Manufacturing Sector }\end{array}$ \\
\hline \multirow[t]{15}{*}{ Washington } & 07: Ag Services, Forestry, and Fishing & 163 & $3,050,000$ & 2.1 & 2.0 & 6.2 & 5.4 & \\
\hline & 0800: forestry & 10 & nd & 0.1 & nd & 3.7 & nd & \\
\hline & 10: Mining & 0 & 0 & 0.0 & 0.0 & 0.0 & 0.0 & \\
\hline & 15: Construction & 358 & $9,420,000$ & 4.6 & 6.2 & 1.8 & 1.7 & \\
\hline & 20: Manulacturing & 1,978 & $58,400,000$ & 25.2 & 38.2 & 2.2 & 2.2 & \\
\hline & 2400: lumber and wood products & 459 & $11,970,000$ & 5.8 & 7.8 & 4.0 & 4.7 & 23.2 \\
\hline & 2410: Logging & 175 & nd & 2.2 & nd & 5.1 & nd & \\
\hline & 2600: paper and allied products & 750 & nd & 9.5 & nd & 5.5 & nd & 37.9 \\
\hline & 40: Transportation and Public Utilities & 297 & $6,150,000$ & 3.8 & 4.0 & 1.5 & 1.1 & \\
\hline & 50: Wholesale Trade & 291 & $3,780,000$ & 3.7 & 2.5 & 1.2 & 0.6 & \\
\hline & 52: Retail Trade & 2,310 & $26,660,000$ & 29.4 & 17.4 & 2.2 & 1.8 & \\
\hline & 60: Finance, Insurance and Real Estate & 333 & $6,450,000$ & 4.2 & 4.2 & 1.3 & 0.9 & \\
\hline & 70: Services & 2,129 & $38,850,000$ & 27.1 & 25.4 & 1.5 & 1.3 & \\
\hline & 99: Unclassified Establishments & 4 & 4,000 & 0.1 & 0.0 & 1.0 & 0.0 & \\
\hline & Total & 7,863 & $152,850,000$ & 100.0 & 100.0 & 1.8 & 1.6 & \\
\hline \multirow[t]{15}{*}{ York } & 07: Ag Services, Forestry, and Fishing & 238 & $4,950,000$ & 0.6 & 0.6 & 9.0 & 8.8 & \\
\hline & 0800: forestry & 10 & nd & 0.0 & nd & 3.7 & nd & \\
\hline & 10: Mining & 13 & 330,000 & 0.0 & 0.0 & 19.4 & 19.8 & \\
\hline & 15: Construction & 2,059 & $48,650,000$ & 4.9 & 5.4 & 10.6 & 9.0 & \\
\hline & 20: Manufacturing & 10,690 & $312,930,000$ & 25.7 & 34.8 & 11.8 & 11.7 & \\
\hline & 2400: lumber and wood products & 393 & $8,400,000$ & 0.9 & 0.9 & 3.4 & 3.3 & 3.7 \\
\hline & 2410: Logging & 30 & 540,000 & 0.1 & 0.1 & 0.9 & 0.7 & \\
\hline & 2600: paper and allied products & 60 & nd & 0.1 & nd & 0.4 & nd & 0.6 \\
\hline & 40: Transportation and Public Utilities & 1,081 & $27,960,000$ & 2.6 & 3.1 & 5.5 & 5.0 & \\
\hline & 50: Wholesale Trade & 1,646 & $45,330,000$ & 3.9 & 5.0 & 6.6 & 6.6 & \\
\hline & 52: Retail Trade & 11,821 & $176,670,000$ & 28.4 & 19.6 & 11.4 & 12.1 & \\
\hline & 60: Finance, Insurance and Real Estate & 1,534 & $36,390,000$ & 3.7 & 4.0 & 6.0 & 4.8 & \\
\hline & 70: Services & 12,527 & $245,940,000$ & 30.1 & 27.3 & 8.6 & 8.1 & \\
\hline & 99: Unclassified Establishments & 64 & 720,000 & 0.2 & 0.1 & 16.8 & 8.7 & \\
\hline & Total & 41.673 & $899,900,000$ & 100.0 & 100.0 & 9.6 & 9.2 & \\
\hline
\end{tabular}




\section{Appendix B}

LD 1892: An Act to Implement the Compact for Maine's Forests 


\title{
Joint Standing Committee on Agriculture, Conservation and Forestry
}

\section{LD 1892 An Act to Implement the Compact for Maine's Forests C.M.R.. Chapter 1}

\author{
Sponsor(s) Committee Report Amendments Adopted \\ SPEAR \\ OTP-AM MAJ \\ H-924 \\ OTP-AM MIN \\ H-931 \\ H-933 \\ S-605 \\ S-606
}

LD 1892 proposed a new forest policy for the State to be placed before the voters as a competing measure to the Citizens' Initiative. An Act to Promote Forest Management and Eliminate Clearcutting. LD 1892 proposed the following:

1. Directing the natural resource educator in the Bureau of Forestry to develop programs for the general public and to develop partnerships and funding sources for creating new natural resource education initiatives for the public.

2. Establishing a permit-by-rule procedure for clear-cutting, increasing the minimum basal area threshold used to define a clear-cut, requiring that clear-cuts have a silvicultural justification and setting limitations on the size ( 75 acres) and arrangement of clear-cuts, with some exemptions provided.

3. Establishing the Sustainable Forest Management Audit Program as a voluntary program within the Department of Conservation for ownerships greater than 100,000 acres in size to ensure the maintenance and enhancement of timber sustainability, the economic viability of forest management and the State's forest biodiversity.

4. Establishing ecological forest reserves on public lands, totaling between 12,000 and 15,000 acres.

5. Directing the Maine Forest Service to undertake a study of liquidation harvesting and make recommendations to further restrict the practice; and

6. Amending the notification requirements for municipalities enacting or amending a timber harvesting ordinance.

Committee Amendment "A" (H-924), the majority report, amended the bill to:

1. Require the Director of the Bureau of Forestry to convene a natural resource education advisory committee to work with the Bureau's natural resource educator. It specifies that the committee include forest landowners, forest products harvesters , forest managers and environmental education organizations.

2. Delete the provision in the bill that exempted from legislative review rules adopted to implement new 
harvesting standards and designate those rules as major substantive rules. requiring legislative review prior to final adoption.

3. Add definitions to clarify the term "landowner" and provide for further definition through rulemaking. This is necessary to implement the provisions which make distinctions between ownerships based on total acres owned.

4. Allow additional information necessary for processing a clear-cut permit to be specified in rule. These rules will come before the Legislature for review. The rules will address any additional information needed for the Commissioner to make a finding on a permit application.

5. Clarify that harvesting of an existing plantation is an accepted purpose for clear-cutting. This purpose was unclear in the original bill.

6. Rewrite the provision on clear-cut separation zones. For parcels of land over 100 acres, the separation zone must equal the clear-cut area in size. For parcels under 100 acres, the minimum separation zone is 250 feet.

7. Clarify existing law relating to municipal timber harvesting ordinances. Municipalities may not adopt ordinances less restrictive than state law.

8. Specify that only the Director of the Bureau of Forestry is authorized to issue a stop work order and that only designated employees are authorized to enforce state forestry laws under Title 12. Chapter 805. subchapter III-A. The original bill allowed any employee of the Department of Conservation to enforce these laws.

9. Restructure and clarify the provisions of the Sustainable Forest Management Audit Program. This was a major rewrite to eliminate repetitive language and clarify responsibilities of the Sustainable Forest Management Audit Board, the Commissioner of Conservation, the Bureau of Forestry, certified auditors and participating landowners. The rewrite specifies that rules adopted by the Commissioner to implement this program are major, substantive rules.

10. Direct the Land and Water Resources Council to assist in determining the need for ecological forest reserves and provide for an interim report on ecological reserves to be submitted to the Joint Standing Committee with jurisdiction over forestry matters by June 1, 1997 and a final report to the Governor and Legislature by January 1, 1998. It gives authority to the Bureau of Parks and Lands to establish ecological forest reserves totaling between 8,000 and 10,000 acres rather than requiring the bureau to establish between 12,000 and 15,000 acres of ecological forest reserves

11. Make changes to Sec. 19 of the bill for consistency and clarity in wording the referendum question.

This amendment made several technical changes to and clarified language in the original bill. It added an appropriations section and a fiscal note to the bill and changed the effective date for those sections of the bill that regulate timber harvesting to allow time for rulemaking to implement the changes.

House Amendment "B" to Committee Amendment "A" (H-931) directed the Sustainable Forest Management Audit Board to establish a working group on cold water fisheries habitat. This group is charged with developing voluntary best management practices for enhanced protection of cold water fisheries habitat. 
House Amendment " $\mathrm{D}$ " to Committee Amendment "A" (H-933) created a new legislative instrument for the consideration of a competing measure to a citizen's initiative.

Senate Amendment "B" to Committee Amendment "A" (S-605) specified that traditional recreation activities must be allowed on lands designated as ecological forest reserves to the same extent those activities would have been allowed on those lands had they not been designated as an ecological forest reserves.

Senate Amendment " $C$ " to Committee Amendment "A" (S-606) required appointments to the Sustainable Forest Management Audit Board to be reviewed by the joint standing committee of the Legislature having jurisdiction over forestry matters and to be confirmed by the Senate.

Committee Amendment "B" (H-925) was the minority report of the committee. The amendment proposed to strike everything in the bill. change its title and replace the bill with language that would have created the Blue Ribbon Commission on the Maine Forests, consisting of 14 voting members, 8 appointed by the Governor and 6 appointed by the Legislature. The Commissioner of Inland Fisheries and Wildlife and the Commissioner of Conservation would have been ex officio, nonvoting members of the blue ribbon commission. The commission would have been required to hold at least 4 public meetings and submit its report and any implementing legislation to the First Regular Session of the 118th Legislature not later than January $15,1977$.

This amendment proposed to make the bill an emergency. This amendment would not have constituted a competing measure and would not have appeared as an alternative on the ballot in November. The Minority Report was not adopted.

\section{Enacted Law Summary}

Resolution, Proposing a Competing Measure under the Constitution of Maine to Implement the Compact for Maine's Forests. The Competing Measure Resolution (C.M.R., Chapter 1) passed during the Second Special Session of the 117th Legislature submits to the voters a measure to be placed on the referendum ballot in November. The resolution will appear on the ballot as a competing measure with Initiated Bill 4, An Act to Promote Forest Rehabilitation and Eliminate Clearcutting. Voter acceptance of the resolution. C.M.R., Chapter 1, would result in enactment of the following provisions:

1. A policy statement regarding forest management and land use.

2. Increased restrictions on clearcutting including a 75-acre maximum (with some exemptions $\&$ variances allowed) and a permit requirement.

3. Enhanced notification requirements for municipalities proposing enactment of or amendments to timber harvesting ordinances and payment to municipalities for associated costs.

4. Establishment of the Sustainable Forest Management Program as a voluntary program within the Department of Conservation to encourage improvement in forest management and to optimize ecological and economic health of the forests.

5. Authorization for the Bureau of Parks and Lands to establish between 8.000 and 10,000 acres of ecological forest reserves on public lands. 
6. Completion by March 1, 1997 of an assessment by the Maine Forest Service of the expected impact of the provisions in this competing measure resolution on timber liquidation. and legislation to be submitted by the Governor by April 1. 1997 to further restrict timber liquidation.

7. Development of natural resource education initiatives for the general public. Convening of a natural resource education advisory committee to work with the natural resource educator in the Bureau of Forestry.

\section{Bill Summaries Page}

\section{OPLA Homepage}

